\title{
Petrological and geochronological constraints on lower crust exhumation during Paleoproterozoic (Eburnean) orogeny, NW Ghana, West African craton.
}

5 Sylvain Block ${ }^{1}$, Jerome Ganne ${ }^{1}$, Lenka Baratoux ${ }^{1}$, Armin Zeh $^{2}$, Luis A. Parra ${ }^{3}$, Mark Jessell ${ }^{3}$, Laurent Ailleres ${ }^{4}$, Luc Siebenaller ${ }^{1}$, Emmanuel Mensah ${ }^{5}$

${ }^{1}$ Geosciences Environnement Toulouse, Observatoire Midi Pyrénées, 14 ave E. Belin, 31400, Toulouse, France.

${ }^{2}$ Institut für Geowissenschaften, Altenhöfer Allee 1, D-60438 Frankfurt am Main, Germany.

${ }^{3}$ Center for Exploration Targeting, The University of Western Australia, 35 Stirling Highway, Crawley, Perth, Western Australia 6009

${ }^{4}$ Monash University, School of Geosciences, Wellington Road, Clayton, Vic 3800, Australia

${ }^{5}$ Geological Survey Department of Ghana.

15 
We present new petrological and geochronological data on high-grade ortho- and paragneisses from north-western Ghana, forming part of the Paleoproterozoic (2.25-2.00 Ga) West African Craton. The study area is located in the interference zone between N-S and NE-SW trending craton-scale shear zones, formed during the Eburnean orogeny $(2.15-2.00 \mathrm{Ga})$. High-grade metamorphic domains are separated from low-grade greenstone belts by high-strain zones, including early thrusts, extensional detachments and late-stage strike-slip shear zones. Paragneisses sporadically preserve high-pressure, low-temperature (HP-LT) relics formed at the blueschist facies boundary $\left(\mathrm{P}=10.0-14.0 \mathrm{kbar}, \mathrm{T}=520-600^{\circ} \mathrm{C}\right)$ and represent a low $\left(\sim 15^{\circ} \mathrm{C} / \mathrm{km}\right)$ apparent geothermal gradient. Monazite crystallisation during granulite- and amphibolite-facies metamorphic overprints is constrained by in-situ U-Pb ages of $2138 \pm 7$ and $2130 \pm 7 \mathrm{Ma}$ respectively. Granulite-facies rocks reveal a clockwise pressure-temperature-time (P-T-t) path characterised by melting at pressures over $10.0 \mathrm{kbar}$, followed by decompression and heating to peak temperatures of $750^{\circ} \mathrm{C}$ at 5.0-8.0 kbar, which fit a $30^{\circ} \mathrm{C} / \mathrm{km}$ apparent geotherm. Amphibolite-facies rocks followed a clockwise P-T-t path characterised by peak metamorphic conditions of 7.0-10.0 kbar at 550$680^{\circ} \mathrm{C}$, which match a $20-25^{\circ} \mathrm{C} / \mathrm{km}$ apparent geotherm. These P-T conditions were reached after prograde burial and heating for some rock units, and after decompression and heating for others. The new dataset challenges the interpretation that metamorphic breaks in the Paleoproterozoic domains of north-western Ghana are due to diachronous Birimian 'basins' overlying a gneissic basement. It suggests that the lower crust was exhumed along reverse, normal and transcurrent shear zones and juxtaposed against shallow crustal slices during the Eburnean orogeny. The Eburnean orogen in NW Ghana is made of distinct fragments with contrasting tectono-metamorphic histories. The range of metamorphic conditions and the sharp lateral metamorphic gradients are inconsistent with "hot orogen" models proposed for many Precambrian provinces. These findings shed new light on the geodynamic setting of craton assembly and stabilisation in the Paleoproterozoic. It is suggested that the metamorphic record of the West African Craton is characteristic of Paleoproterozoic plate tectonics and reflects a transition between Archean and Phanerozoic orogens. 


\section{INTRODUCTION}

Precambrian accretionary orogens provided significant contribution to the Earth's crustal growth due to high juvenile crust production rates, and high degrees of preservation of the newly formed crust through assembly against older cratonic nuclei (e.g. Condie, 1998; Cawood et al, 2009). The Precambrian crust was mainly generated by successive pulses of juvenile magmas during a prolonged tectono-magmatic evolution, as is reflected by a wide range of overlapping geochronological data (e.g. Karlstrom et al., 2001; Väisänen et al., 2001; Zeh et al., 2013 and references therein). The final stages of the evolution of Precambrian accretionary orogens are characterised by tectonic accretion of various units to form stable cratons. Maturing and cratonization of Precambrian accretionary orogens is reflected by changing tectonic styles (e.g. Vanderhaeghe et al., 1998), an increasing contribution of crustal reworking during magmatic activity (e.g. Martin et al., 2005; Laurent et al., 2013) and distinctive metamorphic overprints (e.g. Pitra et al., 2010).

Precambrian accretionary orogens commonly include large proportions of fertile juvenile crust, and show high apparent geothermal gradients. As a consequence, the lithosphere was rheologically weak and a partially molten orogenic lower crust was maintained for relatively long periods. According to some authors, the hot and weak crust accommodated regional shortening by homogeneous, distributed thickening and flow of partially molten rocks (Chardon et al., 2008, 2009; 2011; Cagnard et al., 2006). Precambrian accretionary orogens often comprise very large domains revealing isobaric metamorphic conditions, with isotherms running parallel to the actual surface, except for local temperature anomalies linked to pluton emplacement (e.g. Debat et al., 2003; Vidal et al., 2009). The relative scarcity of strong lateral metamorphic gradients is assumed to result from homogeneous uplift of the entire metamorphic terrane, as opposed to a structurally controlled differential exhumation (Percival et al., 1992; Percival and Skulski, 2000; Cagnard et al., 2007; Gapais et al., 2008; 2009). However, spatial variations in geothermal gradients and contrasting metamorphic grades between domains of similar ages have been reported in some Precambrian orogens (Stevens and Moyen, 2007, Ganne et al., 2012, Block et al., 2013). These findings indicate that the thermal regime of maturing Precambrian accretionary orogens can change in space and time, that exhumation localised by high-strain zones may be viable, and suggest the existence of non-unique tectonic settings. Nevertheless, the interpretation of the tectono-thermal evolution of juvenile Precambrian accretionary orogens requires a comprehensive dataset, which comprises field observations, combined with detailed petrological and geochronological constraints. 
The Leo-Man rise forms the southern part of the West African Craton. It comprises an Archean

90 domain (Fig. 1). The Baoulé-Mossi domain is made up of Birimian greenstone belts (Junner, 1940), juvenile TTG (tonalites-trondhjemites-granodiorites) suites, and granites, with formation ages between 2.25 and 2.00 Ga (e.g. Abouchami et al., 1990; Boher et al., 1992). The Eburnean orogeny (2.15-2.00 Ga) led to the reworking and the stabilisation of the craton. It is associated to regional metamorphism and caused the juxtaposition of different tectono-metamorphic domains. However, the relationship between low-grade and high-grade units remains debated, and the orogenic processes which controlled crustal differentiation and exhumation of high-grade rocks require further constraints. To close this gap of knowledge we present combined petrological and geochronological datasets of spatially associated low-, medium- and high-grade metamorphic rocks of the eastern Baoulé-Mossi domain. The datasets are used to explore the mechanisms driving the exhumation of the Eburnean lower-crust, and the tectonic assembly of the distinct metamorphic domains which crops out in north-western Ghana. Furthermore, the new data sheds new light on the orogenic processes which controlled the maturation and stabilisation of juvenile continental crust following the Archean-Proterozoic transition.

\section{GEOLOGICAL BACKGROUND}

The Birimian greenstone belts of the Paleoproterozoic West African Craton comprise elongated sequences of volcanic and volcano-sedimentary rocks, shales and greywackes, and occasional chemical sedimentary rocks. The volcanic rocks range from basalts to rhyolites and have bimodal tholeiitic and calc-alkaline affinities (e.g. Kitson, 1918; Leube et al., 1990, Baratoux et al., 2011). Across the craton, large volumes of volcanic rocks were emplaced between 2.40 and $2.20 \mathrm{Ga}$ and volcanic activity locally lasted on until c. 2.10 Ga (Hirdes et al., 1996; Kouamelan et al., 1996; Doumbia et al., 1998; Feybesse et al., 2006). The greenstone belts are bounded by shear zones and alternate with granite-gneiss terranes. Intense plutonic activity generated juvenile TTG suites between 2.25 and $2.10 \mathrm{Ga}$, while magmatism gradually evolved towards more differentiated terms (potassic granites and alkaline syenites) until c. 2.08 Ga (e.g. Arnould, 1961; Egal et al., 2002; Lompo, 2009). Following magmatic accretion of the juvenile crust between 2.25 and $2.15 \mathrm{Ga}$, the Paleoproterozoic crust was deformed during the 2.15-2.00 Ga Eburnean orogenic cycle (Bonhomme, 1962; Tagini, 1971; Milési et al., 1989; 1992; Feybesse, 1990; Ledru et al., 1991; Hirdes et al., 1996; Vidal et al., 1996; 2009; Allibone et al., 2002; Feybesse et al., 
2006; Pouclet et al., 1996; 2006). Tarkwaian sedimentary rocks (conglomerates, phyllites and quartzites) form discordant basins on Birimian formations, and are interpreted to represent syn-orogenic to late-stage basins (Davis et al., 1994, Perrouty et al., 2012).

Based on geochemical data, some authors interpret the juvenile Paleoproterozoic West African Craton to have evolved from an oceanic plateau (Abouchami et al., 1990; Boher et al., 1992; Pouclet et al., 1996, Lompo, 2009), while others argue it formed by the accretion of several volcanic arcs (e.g. Vidal and Alric, 1994; Attoh et al., 2006; Dampare et al., 2008). Tectonic accretion is proposed to have been dominated by gravity-driven 'Archean-style' vertical tectonics by one school of thought (e.g. Pons et al., 1995 in Niger; Vidal et al., 1996; 2009 in Côte d'Ivoire), while lateral tectonics with thrust-related crustal thickening, equivalent to processes at work in modern orogens, is invoked by other authors (Milési et al., 1989, 1992; Feybesse et al., 2006 in Ghana).

Systematic spatial variations in metamorphic conditions across the Paleoproterozoic craton were recognised by various authors as early as Roques (1948) and Arnould (1961), who described large domains of exposed migmatitic gneisses juxtaposed with low-grade volcano-sedimentary units in northeastern Côte d'Ivoire and southern Burkina Faso. High-T supra-solidus metamorphic conditions are also reported from formations in southern Ghana (Opare-Addo et al., 1993, Feybesse et al., 2006) and Côte 135 d'Ivoire (Caby et al., 2000). Ganne et al. (2011) showed that rocks from greenstone belts in Senegal, Burkina Faso and Niger experienced different peak metamorphic conditions in the greenschist and amphibolite facies, and at the greenschist-blueschist facies transition. Most volcano-sedimentary sequences are metamorphosed at sub-greenschist and greenschist-facies conditions (e.g. Kribek et al., 2008). Amphibolite-facies metamorphic conditions are found in small volcano-sedimentary slivers within larger greenschist-facies belts. They are interpreted to result from contact metamorphic overprints (e.g. Ndiaye et al., 1989; Vidal and Alric, 1994; Debat et al., 2003; Gasquet et al., 2003) accompanied by doming due to granite emplacement (Pons et al., 1995; Soumaila and Garba, 2006). Other authors identified regional amphibolite-facies metamorphism affecting rocks independently from pluton emplacement (Liégeois et al, 1991 in S Mali; Caby et al, 2000 in NE Côte d’Ivoire; John et al, 1999; 145 Klemd et al., 2002 and Galipp et al, 2003, in Ghana). High-P granulites (Triboulet and Feybesse, 1998; Pitra et al., 2010) and low-P granulites (Caby et al., 2000; Pitra et al., 2010) are described from the boundary between the Archean Kénéma-Man and Paleoproterozoic Baoulé Mossi domains. Most metamorphic rocks from the craton record conditions which fit a moderate to hot apparent geothermal 
gradient $\left(>25^{\circ} \mathrm{C} / \mathrm{km}\right)$ However, metamorphic rocks recording cold $\left(\sim 15^{\circ} \mathrm{C} / \mathrm{km}\right)$ apparent geothermal gradients (Ganne et al., 2011) are found in eastern Burkina Faso.

Historically, the high-grade metamorphic domains were interpreted as the basement below the Birimain volcano-sedimentary sequence. A polycyclic orogenic evolution was suggested on the basis of field relationships reflecting poly-phased structural-metamorphic fabrics (Arnould, 1961; Bard and Lemoine, 1976; Ledru et al., 1991). Following this model, the gneissic basement supposedly pre-dating the Birimian series underwent high-grade metamorphism during an early orogenic event (Sagatzky, 1954; Tempier, 1986; Lemoine et al., 1990; Tshibubudze et al., 2009; Hein, 2010) which is termed “Eoeburnean” (De Kock et al., 2011; 2012, Baratoux et al., 2011; Perrouty et al.; 2012). After the deposition of Birimian sediments, the Paleoproterozoic domains were tectonically assembled against the Archean nucleus during the Eburnean orogeny (Kouamelan et al., 1997), in a predominantly transcurrent tectonic regime (e.g. Ledru et al., 1991; Feybesse, 1990). This polycyclic model is further supported by the recognition of deformed, low-grade upper Birimian volcano-sedimentary basins unconformably overlying basal Birimian rocks (e.g. Milési et al., 1989; Ledru et al., 1991; Vidal et al., 1992; Vidal and Alric, 1994; Pouclet el. al., 1996; Perrouty et al., 2012). In contrast to the polycyclic model, some authors (e.g. Leube et al., 1990, Eisenlohr and Hirdes, 1992, Hirdes et al., 1996, Gasquet et al., 2003) argue for a single orogenic cycle. In this view, volcano-sedimentary basins are considered to be contemporaneous equivalents of volcanic belts and to illustrate lateral facies variations (Leube et al., 1990; Eisenlohr and Hirdes, 1992; Hirdes et al., 1996). The monocyclic model implies that terranes of contrasting metamorphic grade are coeval, and that low-grade metamorphic units represent supracrustal equivalents of high-grade migmatitic gneisses. Consequently, variations in the metamorphic conditions of coeval terranes must result from differential exhumation.

A limited number of geochronological data across the West African Craton point to a prolonged period of metamorphic overprint, which lasted c. 70 Ma. It spans from $2153 \pm 13$ Ma given by a Sm-Nd garnet-whole rock isochron age (Boher et al., 1992) to a 2105-2080 Ma period, defined by U-Pb and Pb$\mathrm{Pb}$ crystallisation ages of zircon, monazite and titanite (Hirdes et al., 1996; Kouamelan et al., 1996; Oberthür et al., 1998; Feybesse et al, 2006; De Kock et al., 2009; Siegfried et al., 2009 and Thomas et al., 2009). Reworking of the Archean nucleus between 2080 and 2030 Ma (Kouamelan et al., 1996, 1997) is supported by geochronological data obtained by different radiometric methods. However, due to the limited number of age data from only a few outcrops throughout the West African Craton, it remains unclear whether the metamorphic overprint was continuous during $\sim 70$ Ma or occurred during several 

monocyclic orogenic models.

\section{GEOLOGY OF NORTH-WESTERN GHANA}

\section{Tectono-metamorphic domains}

The geology of north-western Ghana is characterised by low- to high-grade tectono-metamorphic domains which are transect or limited by high-strain shear zones. Low-grade shales, volcano-sedimentary rocks, lavas such as dacites, andesites and basalts are found in the N-S Wa-Lawra belt (Fig. 2), which is the south-eastern continuation of the Boromo greenstone belt exposed in Burkina Faso (Baratoux et al., 2011; Metelka et al., 2011). Similar low-grade lithologies are found in the E-W trending Julie belt, which also comprises silicic volcano-sedimentary rocks, quartzites and arkoses. The Maluwe basin is a lowgrade tectono-metamorphic domain elongated SW-NE along $\sim 250 \mathrm{~km}$, which tapers off towards the NE to a thin sliver (Fig. 2). It is dominated by greywacke and shales which are intercalated with volcanoclastic rocks and felsic to intermediate lavas, deposited between 2197 and 2125 Ma (De Kock et al., 2009; Thomas et al., 2009). It also comprises chemical sedimentary rocks (Mn-rich cherts), along with gabbros and pyroxenites. The Nangodi belt (Melcher \& Stumpfl, 1994), in the northeastern part of the study area, is formed by a succession of shales, greywacke and Mn-rich cherts alternating with MORBtype basalts overlain by calc-alkaline andesitic to rhyolitic lava flows.

High-grade orthogneisses, paragneisses and metabasites form most of the Bole-Bulenga domain, which is $~ 150$ by $20-80 \mathrm{~km}$ long and elongated along a NNE direction. The paragneisses are derived from pelites, greywacke and volcano-sedimentary rocks. They are intruded by TTG and monzogranite orthogneisses with crystallisation ages between 2195 and 2135 Ma. The lithologies of the Bole-Bulenga domain are frequently migmatitic. To the south of the study area, the Abulembire domain shares many lithological and metamorphic similarities with the Bole-Bulenga domain. It is essentially made of paragneisses, sometimes migmatitic, intruded by TTG and granite orthogneisses, which were emplaced at between ca. 2200 and 2125 Ma (De Kock et al., 2009; Agyei Duodu et al., 2009). The Abulembire domain is limited to the south by the Tarkwaian Bui belt (Zitsmann et al., 1997).

The high-grade domains and low-grade volcano-sedimentary belts are bounded by granitoid domains. They comprise TTG orthogneisses, gabbros, as well as granodiorite and granite plutons with crystallisation ages ranging between ca. 2170 and 2127 Ma (Agyei Duodu et al., 2009). Late-stage 
undeformed potassic porphyric granites, with crystallisation ages ranging between 2128 and 2086 Ma

(Taylor et al., 1992; Agyei Duodu et al., 2009), intrude large swathes of the Koudougou-Tumu granitoid domain (Fig. 2). The Paleoproterozoic rocks are overlain in central Ghana by the Neoproterozoic sedimentary rocks of the Volta basin (Affaton et al., 1980).

\section{Tectonic contacts separating the domains.}

The contacts between the low-grade and high-grade domains are tectonic, and are formed by ductile highstrain zones. The Julie shear zone (SZ) is N-dipping and forms the transition between the KoudougouTumu granitoid domain, to the north, and the Julie belt, to the south (Fig. 2). Within the shear zone, the foliation in shists and gneisses dips $50-70^{\circ} \mathrm{N}$ and carries a stretching lineation plunging down-dip, towards higher grade rocks. The Julie SZ is interpreted as a thrust, consistent with N-S directed shortening. The Bulenga SZ is a N-dipping shear zone which separates the Julie belt, to the north, from the high-grade Bole-Bulenga domain, to the south. The transition between the two domains is formed by a high-strain migmatitic orthogneiss. The gneissic banding has a moderate dip $\left(40-50^{\circ}\right)$ to the $\mathrm{N}$ and bears a mineral stretching lineation consistently plunging NNE, towards decreasing metamorphic grades. Similarly, the Bole SZ separates the southern Bole-Bulenga domain from the Maluwe basin (Fig. 2). It contains a high-strain orthogneiss. The gneissic banding dips $50-70^{\circ}$ to the south, with the stretching lineation plunging down-dip, towards lower grade rocks. Therefore, the tectonic contacts forming the northern and southern limits of the high-grade Bole-Bulenga domains are interpreted as extensional shear zones, consistent with N-S directed extension.

These tectonic contacts are overprinted by later deformation and terminate on younger structures, which formed during NW-SE to E-W directed shortening. The Julie and Bulenga SZ both terminate to the west on the NNW-striking Jang sinistral strike-slip shear zone, along the north-eastern margin of the BoleBulenga domain. The Bole SZ is folded and transposed parallel to a NNE direction, where it is reactivated as a dextral strike-slip shear zone. The N-S Jirapa shear zone separates the Wa-Lawra belt from the Koudougou-Tumu granitoid domain. At its southern extension, the Jirapa SZ transects the BoleBulenga domain and merges with the NE-SW Bole-Nangodi SZ (Fig. 2), which extends for over $300 \mathrm{~km}$ into Burkina Faso (Naba et al., 2004; Ganne et al., 2011). The Bole-Nangodi SZ is an early thrust reactivated during later deformation as a dextral strike-slip shear zone. 


\section{PETROGRAPHY AND MINERAL CHEMISTRY}

Eight rock samples from the Wa-Lawra belt, the Maluwe basin and the Bole-Bulenga and Abulembire domains were investigated during this study (Table 1). Sampling of the main metamorphic domains of north-western Ghana aimed at exploring the variability of metamorphic conditions at regional scale. Other samples were specifically picked along transects across tectonic contacts in order to evaluate metamorphic breaks. For five of these samples, petrographic and mineral descriptions, bulk rock compositions (Table 2), representative mineral compositions (Table 3, S2) and P-T paths are presented in the main text. The three remaining samples are presented as supporting information in Appendix S1. Mineral abbreviations are after Kretz (1983).

\section{High-grade rocks}

Sample BN 43 (Garnet - kyanite-bearing migmatitic gneiss)

Sample BN43 is a migmatitic paragneiss from the southern Bole-Bulenga domain. It was collected at the margin of a foliated granodiorite pluton. The pluton margins consist of a transitional zone evolving from subsolidus amphibolite-facies rocks to supra-solidus high-grade metamorphic rocks. The sample is from an outcrop of stromatic migmatites, which displays foliation-parallel leucosomes connected to granitic dikes oblique to the foliation, suggesting melt transport through the rock. Petrographic relationships are used to define a succession of five metamorphic assemblages identified here as (A) to (E). Paleosomes are composed of oriented Bt, Qz, Pl and globular Grt1 which together belong to an early metamorphic assemblage (A). Garnet 1 has a modal proportion of $\sim 2-4 \%$ in paleosomes (Fig. 5). It is nearly unzoned and has compositions of almandine (Alm $=100 \mathrm{x}$ $\mathrm{Fe} /(\mathrm{Fe}+\mathrm{Mg}+\mathrm{Ca}+\mathrm{Mn})$ 79-81, pyrope $(\operatorname{Prp}=100 \times \mathrm{Mg} /(\mathrm{Fe}+\mathrm{Mg}+\mathrm{Ca}+\mathrm{Mn})$ 13-17, grossular $(\mathrm{Grs}=100 \times$ $\mathrm{Ca} /(\mathrm{Fe}+\mathrm{Mg}+\mathrm{Ca}+\mathrm{Mn})$ 4-5 and spessartine (Sps $=100 \times \mathrm{Mn} /(\mathrm{Fe}+\mathrm{Mg}+\mathrm{Ca}+\mathrm{Mn})$ 5-8 (Fig. 4f). The Anorthite content $(\mathrm{An}=100 \mathrm{x} \mathrm{Ca} /(\mathrm{Ca}+\mathrm{K}+\mathrm{Na}))$ of $\mathrm{Pl}$ in contact with Grt1 in the paleosome ranges between 24 and 26. Neosomes contain euhedral Ky porphyroblasts up to $1 \mathrm{~cm}$ long, set in leucocratic Qz-rich domains, along with Bt and corroded Pl. Kyanite contains inclusions of plagioclase (An21-An25) and white mica (Wm) (Fig. 3c), of which two phases are found. One has a dominant muscovite fraction ((Ms $=100 \mathrm{x}$ $\mathrm{K} /(\mathrm{Na}+\mathrm{K}+\mathrm{Ca}))$ between 63 and 79, with $\mathrm{Si}=3.21-3.09$ a.p.f.u. and $\mathrm{Al}^{\mathrm{vi}} \sim 1.95-1.88$ a.p.f.u (based on 11 
oxygen), while another has a high paragonite fraction $(\mathrm{Pg}=100 \times \mathrm{Na} /(\mathrm{Na}+\mathrm{K}+\mathrm{Ca}))$ of $87-88$, with $\mathrm{Si}=$ 2.95-3.08 a.p.f.u. and $\mathrm{Al}^{\mathrm{vi}}=2.00$ a.p.f.u (110).

We identify a first metamorphic assemblage which consists of mineral phases preserved in paleosomes and included in kyanite: (A): Grt1 + Bt $+\mathrm{Pl}+\mathrm{Ms}+\mathrm{Pg}+$ Qz. Kyanite is interpreted as a peritectic phase produced by the progressive breakdown of muscovite:

$$
\mathrm{Ms}+\mathrm{Pl}+\mathrm{Qz}>\mathrm{Ky}+\text { melt }(=\mathrm{L}) \pm \mathrm{Bt} \pm \mathrm{Kfs}(\mathrm{R} 1)
$$

Following Patiño Douce \& Harris (1998), (R1) may be modelled as follows: 22Ms + 7Pl + 8 Qz > 25 melt $+5 \mathrm{Ky}+5 \mathrm{Kfs}+2 \mathrm{Bt}$. In this sample, R1 illustrates the transition from the metamorphic assemblage (A) to assemblage (B): Grt1 $+\mathrm{Bt}+\mathrm{Ky}+\mathrm{Pl}+\mathrm{Qz}+\mathrm{L}$. Corroded plagioclase in leucosomes shows chemical compositions of An24-28, which partially overlap with compositions of matrix grains. Euhedral kyanite is unresorbed and is overgrown by prismatic sillimanite (Fig. 3c). This relationship illustrates an increase in the modal proportion of aluminosilicate (from 2.4 to $4.1 \%$, Fig. 5) between assemblage (B) and assemblage (C): Grt1 + Bt $+\mathrm{Sil}+\mathrm{Pl}+\mathrm{Qz}+\mathrm{L}$.

Garnet 2 mainly occurs in coarse-grained neosomes. It displays slight chemical zonations from center to rim. Alm content increases from 74 to 78, Sps content decreases from 5 to 2, and Prp content (18-19) and Grs content (2-4) are stable. Retrograde chemical re-equilibration on the garnet margins is documented by decreasing \#Mg $(\mathrm{Mg} /(\mathrm{Mg}+\mathrm{Fe}))$ from 0.17 to 0.10 . Grt2 is mostly globular (subhedral), and commonly forms atolls overgrowing Grt1 and aluminosilcate-bearing leucosomes (Fig. 3a). In leucocratic segregates, Grt2 growth represents a modal proportion increases from 2.3 to $7.7 \%$ (Fig 5). Fibrolite selvedges between Grt1 and Grt2 (Fig. 3b) demonstrate that garnet mode increase occured in the sillimanite stability field. Rare Bt grains within neosomes are corroded. This suggests that Grt2 is a peritectic phase produced by the progressive dehydration-melting of biotite (e.g. Le Breton \& Thompson, 1988; Fig. 3a):

$$
\mathrm{Bt}+\mathrm{Sil}+\mathrm{Pl}+\mathrm{Qz}>\mathrm{Grt} 2 \pm \mathrm{Kfs}+\mathrm{L}(\mathrm{R} 2),
$$

resulting in the formation of assemblage (D): Grt2 $+\mathrm{Bt}+\mathrm{Sil}+\mathrm{Pl}+\mathrm{Qz}+\mathrm{L}$. Kfs is not observed as a product of reactions (R1) nor (R2), as is frequently the case during water-undersaturated melting of metapelites (Carrington \& Watt, 1995). Monazite is restricted to neosomes and is frequently included in Grt2 (Fig. 11i, j). This observation indicates that monazite crystallised before or simultaneously with assemblage (D). 
Large (up to 5mm long) euhedral biotite crystals form selvedge microstructures around

\section{Sample BN47 (Garnet - kyanite - staurolite schist)}

Sample BN47 is from a paragneiss of the Bole-Bulenga domain. It displays a penetrative metamorphic foliation which comprises $\mathrm{Wm}, \mathrm{Bt}, \mathrm{Pl}$ and Qz. The foliation is parallel to a transposed sedimentary layering which controls at the $\mathrm{cm}$ scale the stability and the modal proportion of Grt, St and Ky porphyroblasts. Petrographic relationships allow to define a succession of four metamorphic assemblages identified here as (A) to (D) for this sample. Garnet forms millimetric euhedral grains Grt cores (Grt1, white dashed line in Fig. 3f) contain rare quartz and chlorite inclusions, and have compositions of Prp4-6, Alm70-72, Grs14-16 and Sps7-8. They crystallised in the stability field of an assemblage (A), which includes Grt1 + Chl + Qz, and their modal proportion in favourable (pelitic) layers is $~ 1 \%$ (Fig. 5). Grt rims (Grt2) display abundant small $(\sim 10 \mu \mathrm{m})$ quartz inclusions, they have compositions of Prp10-13, Alm77-80, Grs4-8, Sps1-4 (Fig. 4f), and form 8-9 vol\% of the rock. Core to rim zoning is characteristic 
of garnet growth during prograde metamorphism. Poikilitic staurolite (St1), with a \#Mg of 0.15-0.17, contains quartz and ilmenite inclusion trails oblique to the metamorphic banding (Fig 3f), and is in equilibrium contact with Grt2. These phases allow identifying a metamorphic assemblage (B), which includes Grt2 + St1 + Ilm + Qz. Kyanite forms centimetric elongated porphyroblasts aligned parallel to the fabric, or rotated due to low intensity shearing. It is in equilibrium contact with matrix Bt, Pl, Ilm, Ms and with Grt2. Matrix Bt has compositions of \#Mg = 45-52 with $\mathrm{Ti}^{\mathrm{vi}}$ varying from 0.09 to 0.12 a.p.f.u. Plagioclase displays significant intergrain compositional variations, with An content ranging from 20 to 45. White mica has a Ms composition with a Pg fraction of Pg18-23, $\mathrm{Si}=3.04-3.09$ a.p.f.u and $\mathrm{Al}^{\mathrm{vi}}=1.92$ a.p.f.u (11 O). These phases define assemblage (C) Grt $+\mathrm{Ky}+\mathrm{Bt}+\mathrm{Pl}+\mathrm{Ilm}+\mathrm{Qz} \pm$ Ms. Monazite is devoid of chemichal zoning. It forms elongated grains parallel to the metamorphic banding in the matrix and is also found within kyanite porphyroblasts (Fig. 11g). Hence it crystallised before or during the formation of assemblage (C).

Assemblage (C) is overgrown by post-kinematic inclusion-poor staurolite (St2), which has a \#Mg 0.12-0.15. The modal proportion of St2 (up to 20\%, Fig. 5) is 5-10 times that of poikilitic. Garnet included in St2 is sometimes partly resorbed and replaced by St (black dashed line, Fig 3f). This reflects the transition from the stability field of Ky to that of St across the equilibrated reaction:

$$
0.17 \mathrm{Grt}+1.86 \mathrm{Ky}=0.25 \mathrm{St}+1 \mathrm{Qz}(\mathrm{R} 1)
$$

resulting in the formation of assemblage (D) : Grt $+\mathrm{St} 2+\mathrm{Bt}+\mathrm{Pl}+\mathrm{Ilm}+\mathrm{Qz}$.

Sample BN436 (Garnet - kyanite - gedrite granofels)

Sample BN436 comes from a boudin of competent rock in high-grade meta-sedimentary rocks of the Abulembire domain. It is characterised by a low-Si, high-Al and Mg bulk rock composition, and a high modal proportion of Grt (up to $~ 50 \%$ ). Rock-forming minerals do not display any preferential orientation. The rock comprises Grt, Ky and Ged porphyroblasts, and a mesocratic matrix which includes St, Chl, Pg, Pl, Rt and Qz (Fig. 4). Petrographic relationships allow defining four successive metamorphic assemblages, labelled from (A) to (D). Garnet porphyroblasts have a radius of up to $1 \mathrm{~cm}$, and display a zoning pattern typical of prograde evolution (Fig. 4f). From core to rim, Prp increases from 17-20 to 2632, Grs increases from 3-6 to 6-8, while Alm falls from 76-78 to 61-65 and Sps from 2 to $<1$. Garnet cores preserve multi-mineral inclusions belonging to early metamorphic assemblages. Rare epidote and 
rutile grains are found together in contact with radial chlorite aggregates (\#Mg $=0.39-0.51)$ in Grt cores (Fig. 4a). This suggests the formation of a first stable metamorphic assemblage including Grt + Chl + Ep $+\mathrm{Rt}+\mathrm{Qz}(\mathrm{A})$. Rutile inclusions are sometimes rimmed by ilmenite, suggesting a transition from the stability field of Rt to that of Ilm. Another set of coexisting inclusions provides evidence for a second assemblage which includes Grt + Chl + St + Pg + Pl + Ilm + Qz (B) (Fig. 4b). Pl from assemblage (B) is strongly sericitised. The Pg content of white mica is $0.77-0.83$, with $\mathrm{Si}=2.84-3.02$ a.p.f.u. and $\mathrm{Al}^{\mathrm{vi}}=1.95$ a.p.f.u (11 O), while St has a \#Mg of 0.07-0.10.

Garnet outer cores contain rare Ky, Bt and Pl (An45-47) inclusions. Grt rims are in contact with matrix Ky, Ged and Pl (Fig. 4c, d). Gedrite displays small chemical variations: the \#Mg is between 0.58 and $0.61, \mathrm{Al}^{\mathrm{iv}}$ ranges from 1.3 to 1.7 a.p.f.u., and $\mathrm{Al}^{\mathrm{vi}}$ is between 1.1 and 1.4 a.p.f.u. $(\mathrm{Na}+\mathrm{K})_{\mathrm{A}}$ content is 0.21-0.31 a.p.f.u. and $(\mathrm{Na}+\mathrm{Ca})_{B}$ is $0.12-0.17$ a.p.f.u., on the basis of 23 oxygen. Biotite grains have a \#Mg $\sim 0.54$, and the matrix Pl An content is 57-71. Ilmenite is absent from the matrix, suggesting that it does not belong to the peak metamorphic assemblage. Rutile is present in Grt outer core, in Ged, and is common in the matrix. These relationships indicate the crossing of the following pressure-dependent reaction (Bohlen \& Liotta, 1986):

$$
\mathrm{Pl}+\mathrm{Ilm}+\mathrm{Qz}=\mathrm{Grt}+\mathrm{Rt}(\mathrm{R} 1)
$$

and the formation of the peak metamorphic assemblage (C): Grt $+\mathrm{Ky}+\mathrm{Ged}+\mathrm{Pl}+\mathrm{Rt}+\mathrm{Qz} \pm \mathrm{Bt}$. Monazite is unzoned and is only preserved as single grain inclusions in garnet porphyroblasts (Fig 11f), suggesting that it crystallised before the formation of assemblage (C).

The peak metamorphic assemblage is overgrown by fibrous Chl (\#Mg $=0.70-0.74)$ and euhedral St (\#Mg = 0.16-0.23), while Ged is pseudomorphosed by intergrown Pg and Chl (Fig. 4c, d). This reflects secondary hydration and the local formation of a late metamorphic assemblage which includes Grt + Pg + $\mathrm{Chl}+\mathrm{St}+\mathrm{Qz}(\mathrm{D})$.

\section{Chlorite-mica schists}

\section{Sample BN185 (volcano-sedimentary rock)}

Sample BN185 is an Al-rich silicic volcano-sedimentary rock intercalated in a sequence of volcanic and volcanoclastic rocks, and originates from the north-western Wa-Lawra belt. It develops a schistosity, 

occasionally forms aggregates elongated parallel to the schistose fabric. Chlorite and white mica show strong inter-grain chemical variations. Chlorite \#Mg varies between $0.42-0.52$, although most values cluster in the range $0.47-0.50$. White mica has a strong muscovite fraction, $\mathrm{Ms}(=100 \mathrm{x} \mathrm{K} /(\mathrm{K}+\mathrm{Na}+\mathrm{Ca})$ ) varies from 89 to 99 (Table S2). Chemical compositions of chlorite and white mica from sample BN185 are presented in ternary diagrams in Fig. 6. They show the fractions of amesite, sudoite and clinochlore + daphinte end-members in chlorite; and those of muscovite, celadonite and pyrophyllite end-members in white mica.

\section{Sample BN246 (Micaschist)}

Samples BN246 is a micaschist sampled in the southern Maluwe basin, in the vicinity of a high-strain zone mineralised in gold, at the contact between meta-sedimetary rocks and an elongated granodiorite body. It displays an assemblage of intergrown quartz-chlorite-muscovite, and a marked mineral orientation parallel to the schistosity. White mica is the least abundant of the three phases. It has variable compositions, with muscovite fraction ranging from Ms74 to Ms95 (Table S2), Si = 3.10-3.40 a.p.f.u. and $\mathrm{Al}^{\mathrm{vi}}=1.80-1.95$ a.p.f.u (11 O). Chlorite \#Mg is within 0.31-0.36, $\mathrm{Si}=2.64-2.75$ a.p.f.u., $\mathrm{Al}^{\mathrm{vi}}=1.46-1.52$ (14 O). The sample contains abundant pyrite and is cross-cut by pyrite-calcite veins.

\section{Complementary samples}

Among the three complementary samples presented in Appendix S1 and Fig. S1, two have compositions suggesting greywacke or pelitic protoliths (BN534, BN491), and one is derived from a gabbro or a basalt

(BN365). The following assemblages are interpreted to be formed under peak metamorphic conditions $\mathrm{Grt}+\mathrm{Bt}+\mathrm{Ky}+\mathrm{Rt}+\mathrm{L}(\mathrm{BN534}), \mathrm{Grt}+\mathrm{Bt}+\mathrm{Ky}+\mathrm{Ms}+\mathrm{Ilm}(\mathrm{BN} 491)$ and $\mathrm{Grt}+\mathrm{Hbl}+\mathrm{Cpx}+\mathrm{Ilm}+\mathrm{L}$ (BN365). Pl + Qz are present in all three samples. 
P-T conditions and P-T paths were constrained by using the P-T pseudosection method and geothermobarometry using a multi-equilibria method. The pseudosection method is used to infer P-T conditions and P-T-t paths (e.g. Zeh, 2001; Zeh et al.; 2004, Johnson et al., 2008; Millonig et al., 2010) by comparison between observed mineral assemblages, mineral modes, mineral compositions and zoning patterns; with those obtained by P-T pseudosection calculations based on thermodynamic models (De Capitani and Brown, 1987; Powell et al., 1998; Connolly and Petrini, 2002; Powell and Holland, 2010). In this study, P-T pseudosections were constructed using the Perplex software (Connolly, 2005). Pseudosections used to constrain the prograde evolution of migmatite samples were constructed by using an average composition of subsolidus paragneiss (Table 2, Appendix S2). Garnet porphyroblast fractionation was taken into account when its mode was found to be significant (> 1vol\%). Methodological details relevant for individual samples are described in Appendix S2, along with the chosen solution models.

In addition, the multi-equilibria method was employed to set further constraints on the P-T evolution of the rocks (e.g. Berman, 1991). This method is appropriate to constain P-T conditions and P-T paths in greenschist- to amphibolite-facies metamorphic rocks characterised by high variance assemblages (e.g. Vidal et al, 2006 and references therein). Studies on natural metapelite samples have shown that minerals from different microstructural domains (foliations, shear bands, etc) of a single thin section can represent different local equilibria, and therefore reflect different P-T conditions (e.g., Vidal et al., 2001, 2006; Parra, 2002; De Andrade et al, 2006; Vidal et al, 2006; Yamato et al, 2007a; Ganne et al, 2012). Compositions of the minerals used for P-T calculations are presented in Table S2, and calculation details are given in Appendix S3.

\section{Geochronology}

435 A first set of analyses was performed in-situ on polished thin sections of samples BN436, BN47 and BN43, using laser ablation - inductively coupled plasma - sector field - mass spectrometry (LAICP(SF)-MS) at Goethe University Frankfurt (Appendix S4). Prior to LA-ICP(SF)-MS, the internal structure of each monazite grain was characterised by raster electron microscopy (REM) at Geosciences Environnement Toulouse using a JEOL SM-6360 OLV Scanning Electron Microscope. A second set of analyses was carried out in-situ on polished thin sections of samples BN47 and BN43, using Sensitive High Resolution Ion MicroProbe (SHRIMP II) at the John de Laeter Centre for Isotope Research (JLC), 
Curtin University, Perth, Australia (Appendix S4). Monazite crystals from sample BN436 were only dated using LA-ICP-MS at GUF.

\section{RESULTS}

\section{P-T conditions and P-T paths}

Sample BN43 (Garnet - kyanite-bearing migmatitic gneiss)

P-T pseudosections built for migmatite sample BN 43 are presented in Fig. 7. Subsolidus conditions of 6.5-9.5 kbar, $600-670^{\circ} \mathrm{C}$ are deduced from the equilibrium conditions of Grt1 (Prp13-17, Grs3-5) and plagioclase in paleosome (An 24-26) (Fig. 7b). These conditions partly overlap with the calculated stability conditions of the metamorphic assemblage $\mathrm{Bt}+\mathrm{Grt}+\mathrm{Pl}+\mathrm{Ms}+\mathrm{Pg}+\mathrm{Rt}+\mathrm{Qz}$. This assemblage is identical to assemblage (A) except for rutile, which was not observed and may have totally reacted out. The composition of Pl preserved in Ky (An21-25) requires crossing (R1) at P=10.0-11.0 (Fig. 7c, d). The formation of assemblage (B) requires decompression to below $9.0 \mathrm{kbar}$ at $680-750^{\circ} \mathrm{C}$. We deduce the 455 shape of the P-T path based on constraints drawn from the following observations:

(1) Aluminosilicate mode increases in the stability field of sillimanite.

(2) Garnet2 formation by reaction (R2) represents an increase in Grt mode in the stability field of sillimanite.

Modelling results show that aluminosilicate mode decreases with increasing T (Fig. 7c), hence (1) requires decompression without heating from the stability field of assemblage (B) to that of assemblage (C), below 7.0-9.0 kbar. Garnet mode increases with increasing T, therefore (2) implies a temperature increase under conditions corresponding to the stability of assemblage (C) (Fig. 7b). Grt2 crystallisation in assemblage (D), which post-dates or is coeval with monazite crystallisation in neosomes, corresponds to peak temperature conditions of $\sim 750^{\circ} \mathrm{C}$. If $\mathrm{H}_{2} \mathrm{O}$ saturation conditions are met on the wet solidus at 10 465 kbar, melt is generated in sufficient amount at peak T (>5 vol\%, Fig. 7d) for it to segregate (e.g. Arzi, 1978; Sawyer, 1994; Brown et al., 1995), inducing open system behaviour (Appendix S2). The absence of cordierite constrains pressure along the retrograde path to be above 5 kbar. This is consistent with the composition of retrograde $\mathrm{Bt}(\# \mathrm{Mg}=0.51-0.56)$. Calculation results show that assemblage $(\mathrm{E})$, which includes retrograde St and Ilm, formed between 4.5-8.0 kbar and $<640{ }^{\circ} \mathrm{C}$ (Fig. 7d). 
$20^{\circ} \mathrm{C} / \mathrm{km}$ apparent geothermal gradient (calculated for an average density $\left.\rho=2750 \mathrm{~kg} \cdot \mathrm{m}^{3}\right)$. High-P $(>10$ kbar) melting is followed by near isothermal decompression to $\mathrm{P}=6.0-8.0 \mathrm{kbar}$. The rock then underwent a metamorphic overprint at the transition between the amphibolite and granulite facies. Recorded peak $\mathrm{T}$ conditions fit a hot $30-35^{\circ} \mathrm{C} / \mathrm{km}$ apparent geotherm.

Sample BN47 (Garnet - kyanite - staurolite schist)

Results of P-T pseudosection construction are presented in Fig. 8. Comparing modelled and measeured Grt compositions provides constraints for a prograde evolution with increasing $\mathrm{T}$ and decreasing $\mathrm{P}$, from the nucleation of garnt core (Grt1) at $11-14 \mathrm{kbar}, 520-560^{\circ} \mathrm{C}$ to growth of garnet rim (Grt2) at 9.0-13.0 kbar, $570-600^{\circ} \mathrm{C}$ (Fig. 8b). The conditions of garnet core formation correspond to the calculated stability field of the assemblage Chl $+\mathrm{Ms}+\mathrm{Cld}+\mathrm{Pg}+\mathrm{Grt}+\mathrm{Rt}$. However, assemblage (A) is not fully characterised and only Chl inclusions are preserved in Grt1.. The absence of Cld and Pg may be due to their complete consumption by prograde metamorphic reactions. Garnet2 is predicted to be in equilibrium with St1 (\#Mg = 0.15-0.17) at around $11.0 \mathrm{kbar}, 600^{\circ} \mathrm{C}$ (Fig. 8c). These conditions correspond to the stability field of Grt $+\mathrm{St}+\mathrm{Chl}+\mathrm{Ms}+\mathrm{Pg}+\mathrm{Rt}$, while assemblage (B) was found to consist in Grt2 + St1 + Ilm + Qz. The discrepancies between the observed and calculated assemblage may be due to the complete compsumption of chlorite and white micas, and to the retrogression of rutile to ilmenite during subsequent metamorphic evolution.

Further information on the shape of the P-T path may be drawn from the observation that Grt2 is in equilibrium contact with Ky. No new Grt growth occurred between assemblage (B) and assemblage (C) Grt2 $+\mathrm{Ky}+\mathrm{Bt}+\mathrm{Pl}+\mathrm{Ilm}+\mathrm{Qz} \pm$ Ms. Fig. 8b shows that such an evolution first requires decompression without any temperature increase, down into the ilmenite stability field (in agreement with the observation of Ilm in St1), at $\mathrm{P}<9.5 \mathrm{kbar} \mathrm{T}>550{ }^{\circ} \mathrm{C}$, followed by near isobaric heating up to at least $650^{\circ} \mathrm{C}$, at 8.0-9.0 kbar. Monazite is interpreted to have crystallised close to peak temperature conditions. The rock then crossed reaction R1 and assemblage (D): Grt $+\mathrm{St} 2+\mathrm{Bt}+\mathrm{Pl}+\mathrm{Ilm}+\mathrm{Qz}$ formed at 4.0-7.0 kbar, $600-650^{\circ} \mathrm{C}$. The modal proportion of St is expected to increase from 2-4 to $16-19$ vol\% between (B) and (D) (Fig. 8c), in agreement with observations. 
Results from P-T modelling reveal a clockwise P-T path for sample BN47. Grt cores represent HP-LT metamorphic relics formed near to the transition between the blueschist facies and the epidote amphibolite sub-facies, along a cold $\sim 15^{\circ} \mathrm{C} / \mathrm{km}$ apparent geothermal gradient. Following near isothermal decompression and near isobaric heating, peak temperature was reached in the amphibolite-facies (Fig. $8 \mathrm{~d})$, at conditions which reflect a moderate, $\sim 25^{\circ} \mathrm{C} / \mathrm{km}$ apparent geotherm.

Sample BN436 (Garnet - kyanite - gedrite granofels)

Figure 9 presents results of P-T pseudosection construction. The coexistence of Grt in equilibrium with Rt and Ep (modelled here as zoisite in the absence of $\mathrm{Fe}^{3+}$, Appendix S2), as evidenced by assemblage (A): Grt + Chl + Ep + Rt + Qz, implies that the sample crossed the Grt in reaction at pressures above 7.0 kbar, $\mathrm{T} \sim 520^{\circ} \mathrm{C}$ (invariant point $\boldsymbol{i}$, Fig. 9b). The calculated assemblage Grt $+\mathrm{Chl}+\mathrm{Zo}+\mathrm{Pg}+\mathrm{Cld}+\mathrm{Rt}+\mathrm{Qz}$ is the closest match to assemblage (A), but Cld was not observed, possibly due to to complete consumption by prograde metamorphic reactions. The compositions of Grt core and St1 (Prp 17-20, Grs3-6; and \#Mg< 0.10 respectively; dark shaded areas in Fig. 9b) suggest that assemblage (B): $\mathrm{Grt}+\mathrm{Chl}+\mathrm{St}+\mathrm{Pl}+\mathrm{Pg}+$ Ilm + Qz, formed at 5.0-6.5 kbar, $550-600^{\circ} \mathrm{C}$. T Petrological relationships and calculated isopleths provide evidence for a prograde evolution from 7.0-8.0 kbar, $\sim 520^{\circ} \mathrm{C}$ to $5.0-6.5 \mathrm{kbar}, 550-600^{\circ} \mathrm{C}$.

Following the formation of assemblage (B), the rock crossed reaction R1, out of the stability domain of Ilm (pale shaded area in Fig. 9b) into that of Rt. This requires a pressure increase above 7.0 kbar. The formation of An50 Pl included in Grt outer cores (Fig. 9b) and of the peak metamorphic assemblage (C): Grt + Ged $+\mathrm{Ky}+\mathrm{Pl}+\mathrm{Rt}+\mathrm{Qz} \pm \mathrm{Bt}$ (shaded area, Fig. 9d) implies further burial and heating. Peak conditions of $6.5-8.5 \mathrm{kbar}, 650-700^{\circ} \mathrm{C}$ are deduced from the comparison of calculated and measured compositions of Grt, Ged and Pl (Fig. 9d). The pseudosection provides a satisfactory explanation for the observed crystallisation sequence of Ti-phases : Rt $>$ Ilm $>$ Rt. Monazite preserved in garnet porphyroblasts crystallised along the prograde path at $\mathrm{T}<640^{\circ} \mathrm{C}$, before the formation of assemblage (C). The absence of cordierite or sillimanite suggests that the rock underwent limited decompression during the retrograde metamorphic overprint. Cooling down to $\mathrm{T}<530^{\circ} \mathrm{C}$ is reflected by the crystallisation of minerals belonging to assemblage (D). 
amphibolite facies correspond to a moderate to warm, $\sim 30^{\circ} \mathrm{C} / \mathrm{km}$ apparent geothermal gradient. They overprint relics of an early metamorphic assemblage (A) formed under conditions which fit a lower, $\sim 20^{\circ} \mathrm{C} / \mathrm{km}$ apparent geotherm. In the absence of post-peak decompression, a tight P-T loop is suggested.

Sample BN185 (volcano-sedimentary schist)

Table 4 shows compositions of white mica and chlorite pairs which met equilibrium, along with corresponding equilibrium conditions, determined by the multi-equilibria method. Three compositionally different chlorite-phengite couples, equilibrated in different $\mathrm{P}-\mathrm{T}$ range were identified. Low-Si $(\mathrm{Si}<2.75$, based on 14 oxygen) chlorite and low-K white mica $(\mathrm{K}<0.80$, based on 11 oxygen) equilibrated at $>$ $300^{\circ} \mathrm{C}$ and up to $10 \mathrm{kbar}$ (group A). Moderate-Si $(2.75<\mathrm{Si}<2.82)$ chlorite and moderate-K $(0.80<0.85)$ white mica formed between 250 and $300{ }^{\circ} \mathrm{C}$, below 5 kbar (group B). High-Si (Si > 2.82) chlorite and high-K $(\mathrm{K}>0.85)$ white mica equilibrated at $<250^{\circ} \mathrm{C}$, below 4 kbar (group $\mathrm{C}$ ). They together define near-continuous P-T conditions from $\sim 10 \mathrm{kbar}, 450^{\circ} \mathrm{C}$, to $1 \mathrm{kbar}, 220^{\circ} \mathrm{C}$ (Fig. 10). Peak metamorphic conditions correspond to burial along an apperent geothermal gradient of $\sim 15^{\circ} \mathrm{C} / \mathrm{km}$, at the transition between the greenschist and blueschist facies. The sample was then exhumed along a decompressioncooling path.

\section{Sample BN246 (Micaschist)}

545 The overlap of P-T conditions obtained independently from the Chl-Qz- $\mathrm{H}_{2} \mathrm{O}$ and $\mathrm{Ph}-\mathrm{Qz}-\mathrm{H}_{2} \mathrm{O}$ equilibria provide conditions of possible equilibrium. For sample BN246, they define an area in P-T space ranging from $310-380^{\circ} \mathrm{C}$ at $2.0 \mathrm{kbar}$ to $420-480^{\circ} \mathrm{C}$ at $9.5 \mathrm{kbar}$. The results are presented in Figs. 12, 13.

\section{Complementary samples}

550 Results of metamorphic P-T conditions determination for samples BN365, BN491 and BN534 are presented in Appendix S1, Fig. S2, S3; and are displayed in Fig. 12, 13. Samples BN365 and BN534 record supra-solidus peak metamorphic conditions at 10.0-12.0 kbar, 700-800 ${ }^{\circ} \mathrm{C}$; and 9.5-11.5kbar, 680$750^{\circ} \mathrm{C}$, respectively. Sample BN491 records prograde burial and heating up to peak conditions of 7.5-9.5 
kbar, $610-650^{\circ} \mathrm{C}$, and a retrograde overprint at 4.0-7.0 kbar, 550-610 ${ }^{\circ} \mathrm{C}$. All samples reveal a clockwise P-T evolution.

\section{Geochronology}

Sample BN43 (Garnet - kyanite-bearing migmatitic gneiss)

A total of $22 \mathrm{U}-\mathrm{Th}-\mathrm{Pb}$ LA-ICP-MS spot analyses were carried out on 12 monazite grains from sample

BN43. This includes 8 analyses on 4 grains located in leucosomes, 9 analyses on 4 grains located in biotite selvedges, and 5 analyses on 3 grains located in peritectic garnet (Table 5). Ten concordant analyses from grains in every textural setting yielded a U-Pb Concordia age of 2137.1 $\pm 7.6 \mathrm{Ma}$ $\left(\right.$ MSWD $_{\mathrm{C}+\mathrm{E}}=0.25$, Probability ${ }_{\mathrm{C}+\mathrm{E}}=0.99, \mathrm{C}+\mathrm{E}=$ concordance and equivalence; Fig. 11a). This result is also supported by $17 \mathrm{U}-\mathrm{Th}-\mathrm{Pb}$ analyses on 10 monazite grains by using the SHRIMP method ion microprobe, located in peritectic Grt2, in neosomes and in the matrix. Among them, 9 concordant analyses on 5 monazite grains situated in every textural setting provided an identical within errors Concordia age of 2141.2 \pm 6.4 Ma, $\left(\right.$ MSWD $_{C+E}=1.3$, Prob. ${ }_{C+E}=0.19$; Fig. 11b). However, three LA-ICPMS spots performed on a single grain (grain $n^{\circ} 1$, Table 5, Fig. 11a) reveal a significantly older imprecise upper intercept age of $c$. 2211 $\pm 62 \mathrm{Ma}$ (MSWD=0.65, Probability=0.42). The $c$. 2140 Ma Concordia age is interpreted to date melting in sample BN43, which happened prior to metamorphic peak T. The c. 2210 Ma age may reflect an inherited component in the volcano-sedimentary protolith of the rock.

Sample BN47 (Garnet - kyanite - staurolite schist)

Seventeen U-Th-Pb LA-ICP-MS spot analyses were carried out on 4 monazite grains from in sample BN47. Among them, 5 analyses were performed on a grains enclosed by staurolite porphyroblasts, 9 on two grains elongated parallel to the metamorphic banding in the matrix, and 3 on a grain included in matrix biotite (Table 5). All LA-ICP-MS analyses (except one) yielded identical ${ }^{207} \mathrm{~Pb} /{ }^{206} \mathrm{~Pb}$ ages within errors of about $2130 \mathrm{Ma}$ (weighted mean ${ }^{207} \mathrm{~Pb} /{ }^{206} \mathrm{~Pb}$ age $=2127 \pm 7 \mathrm{Ma}$; MSWD=1.5, $\mathrm{n}=16$ ), and eleven of them give a U-Pb Concordia age of 2127.0 \pm 7.4 Ma $\left(\mathrm{MSWD}_{\mathrm{C}+\mathrm{E}}=0.67\right.$, Prob. ${ }_{\mathrm{C}+\mathrm{E}}=0.87$; Fig. 11c). The Concordia age is identical to an upper intercept age of 2130.2 \pm 6.4 Ma (MSWD=1.3, Prob.=0.2) obtained by SHRIMP on 18 monazite grains (Fig. 11d) enclosed in kyanite porphyroblasts or found in the matrix. The c. $2130 \mathrm{Ma}$ age is interpreted to date the peak of the amphibolite-facies metamorphic overprint, which is reflected by assemblage (C) in sample BN47. 
Sample BN436 (Garnet - kyanite - gedrite granofels)

Twenty-one U-Th-Pb laser spot analyses were carried out on 11 monazite grains devoid of anychemical zoning and located in garnet porphyroblats of sample BN436. Eighteen of these analyses yielded a U-Pb Concordia age of 2131.0 \pm 6.4 Ma $\left(\operatorname{MSWD}_{\mathrm{C}+\mathrm{E}}=0.35\right.$, Probability ${ }_{\mathrm{C}+\mathrm{E}}=0.99$, Fig. 11e). This age is interpreted to date prograde metamorphism in sample BN436.

\section{DISCUSSION}

\section{Metamorphic synthesis}

Figure 12 presents a simplified metamorphic map showing the spatial distribution of metamorphic facies in north-western Ghana, based on field mapping, along with P-T conditions and P-T paths of the studied samples. Figure 13 displays the P-T conditions and P-T paths recorded by all studied samples in order to illustrate the variability of metamorphic conditions and P-T paths across the study area. Four sets of distinct P-T paths and P-T conditions are revealed in the metamorphic domains of the study area (Fig. 12, 13):

- Burial along a cold, $\sim 15^{\circ} \mathrm{C} / \mathrm{km}$ at $\mathrm{P}=7.0-13 \mathrm{kbar}$ formed HP-LT metamorphic relics along the greenschist-blueschist facies boundary, at 8.0-10.0 kbar, 400-500 C (BN185, Fig. 12a); or at the transition between the blueschist facies and the epidote-amphibolite sub-facies, at 11-14 kbar, $520-560^{\circ} \mathrm{C}$ (BN47, Fig. 12c). They provide evidence for an early metamorphic phase and a relatively cold thermal environment.

- $\quad$ Rocks metamorphosed at the granulite-amphibolite facies transition in the Bole-Bulenga domain provide evidence for melting at relatively high pressure of 8.0-12.0 kbar (. Peak temperatures of $700-800^{\circ} \mathrm{C}$ are either reached near to peak P (samples BN534, BN365, Fig. 12b, f), or following a phase of isothermal decompression (BN43, Fig. 12d).

- The Bole-Bulenga and Abulembire domains were subject to regional scale amphibolite-facies metamorphism. Some rock units were buried along an apparent geothermal gradient of 20$30^{\circ} \mathrm{C} / \mathrm{km}$ and reached simultaneous peak $\mathrm{P}$ and $\mathrm{T}$ conditions of $6.0-9.0 \mathrm{kbar}$ at $550-680^{\circ} \mathrm{C}$ (samples BN491 and BN436, Fig. 12e, This metamorphic overprint is recorded in older metamorphic rocks, represented by HP-LT relics and granulites. It follows a phase of 
exhumation, which is suggested by near isothermal decompression paths in rocks metamphosed at higher P (Fig. 13).

- Metamorphic rocks from the Maluwe domain, (BN 246, Fig. 12g), reached peak conditions in the greenschist-facies, at P-T conditions of $2.0-9.5 \mathrm{kbar}, 310-480^{\circ} \mathrm{C}$. The interpretation of such metamorphic conditions is not clear because of the large pressure uncertainty.

In high-grade metamorphic domains, the P-T paths of the studied samples seem to merge at 5.0-8.0 kbar, $550-650^{\circ} \mathrm{C}$ (Fig. 13), which corresponds to conditions of the amphibolite-facies metamorphic overprint. This evolution documents a change in the thermal regime of the crust. It may be interpreted as the result of thermal re-equilibration of the various high-grade units which were tectonically assembled in the lower crust (England \& Thompson, 1984) along a $\sim 30^{\circ} \mathrm{C} / \mathrm{km}$ apparent geotherm (Fig. 13). However, the amphibolite-facies regional metamorphic overprint is not documented in sample BN185. The overprint may have been spatially limited so that the early metamorphic evolution characterised by a cold apparent geotherm was preserved away from the Bole-Bulenga and Abulembire domains. Alternatively, these conditions may be coeval with high-grade metamorphism.

In any case, the metamorphic record of the Paleoproterozoic craton of north-western Ghana shows that low-grade and high-grade rocks are juxtaposed (Fig 12, 13). The coexistence of distinct P-T paths and P-T conditions at regional scale implies that rock units forming the Eburnean crust witnessed an evolution in contrasting thermal environments. In turns, the diversity of thermal environments may reflect various tectonic settings which existed before the final amalgamation and stabilisation of this part of the craton.

\section{Regional evolution}

Geochronological constraints provide evidence for granulite-facies metamorphism in paragneisses of the Bole-Bulenga domain at c.2140 Ma; and for an amphibolite-facies regional metamorphic overprint between 2137 and 2120 Ma. The high-grade metamorphic event is recorded in both the Abulembire and Bole-Bulenga domains, which suggests that they belonged to the same crustal slice at that time. It was not possible to date the early metamorphic evolution associated to HP-LT relics. Therefore, the timing of burial along a relatively low $\mathrm{dT} / \mathrm{dP}$ apparent geothermal gradient $\left(\sim 15^{\circ} \mathrm{C} / \mathrm{km}\right)$ remains unconstrained. Rocks could have followed a continuous evolution from blueschist-facies to high-T amphibolite facies 
with increasing $\mathrm{T}$ and decreasing $\mathrm{P}$ during a single burial-exhumation cycle. Conversely, based on our data, we cannot exclude diachronism between HP-LT metamorphism and anatexis.

A crystallisation age of 2196 \pm 1 Ma was obtained from rhyolitic pyroclastites from the Maluwe basin by Agyei Duodu et al. (2009). It is identical within errors to the crystallisation ages of orthogneisses intrusive the high-grade paragneisses of the Bole-Bulenga terrain (De Kock et al., 2009). This constraint indicates that the rocks in both high-grade and low-grade domains formed prior to the orogenic cycle linked to high-grade metamorphism. We infer from this that the metamorphic breaks across the study area are the result of the tectonic juxtaposition of coeval units, which represent different slices of the same orogen. Furthermore, De Kock et al. (2009) obtained crystallisation ages of $2131 \pm 4$ Ma from lapilli tuff interbedded with greywacke in the Maluwe basin, indicating synchronous volcanic activity and crustal anatexy. Consequently, we consider that the term "basin” is inadequate to qualify the low-grade Maluwe tectono-metamorphic domain, as there is no basin-basement relationship between the Maluwe and BoleBulenga rocks. The Maluwe domain rather represents a shallow crustal slice of the Eburnean orogeny, which did not witness much burial. A similar conclusion could be drawn for the low-grade units of the Wa-Lawra belt, based on the minimal deposition ages of $2139 \pm 2$ Ma obtained for low-grade volcanosedimentary rocks located to the West of the Jirapa shear zone (Agyei Duodu et al., 2009). The 21452120 Ma age for high-grade, near-peak T metamorphism overlaps with the crystallisation age of intrusive granodiorites and monzogranites in the Bole-Bulenga and Maluwe domains, and in the Wa-Lawra granitoid domain (Fig. 2). The granitoids crystallised between 2120 and 2115 Ma are volumetrically significant (Siegfried et al., 2009; Thomas et al., 2009; De Kock et al., 2009; 2011), which suggests that partial melting continued, and possibly propagated in the lower crust, with the migmatite front migrating downwards from the current-day exposed surface.

Our results show that the study area exposes different crustal levels, belonging to the same Paleoproterozoic orogenic crust, metamorphosed in the greenschist- to granulite-facies, before being tectonically juxtaposed. These conclusions do not support the poly-cyclic orogenic model for this portion of the West African Craton. They also ares at odds with the vast isobaric domains and high dT/dP thermal regimes reported from Precambrian accretionary belts (Sandiford, 1989, Percival and Skulski, 2000), which are considered to be typical of 'hot' orogens (Cagnard et al., 2006, Gapais et al., 2009).

\section{Burial and exhumation}


This study reveals that supracrustal rocks were buried in the lower crust, at up to $13.0 \mathrm{kbar}$, and along a $\sim 15^{\circ} \mathrm{C} / \mathrm{km}$ apparent geotherms. This pressure corresponds to a $\sim 45 \mathrm{~km}$ depth, which represents a minimum thickness for the crust at that time. In modern orogens, such thermal conditions are met in accretionary prisms and during the early stages of crustal thickening, before thermal relaxation of the thickened crust (e.g. Stöckhert \& Gerya, 2005, Yamato et al., 2007b). Burial of rocks metamorphosed under these conditions is attributed to thrusting and crustal thickening, while exhumation is proposed to be driven by boundary tectonic forces and prism corner flow (e.g. Burov \& Yamato, 2008). In northwestern Ghana, early thrust zones brought in contact different metamorphic units and have some control on the present-day distribution of metamorphic grades (Fig. 12). We propose that thrusting can account for the documented crustal thickening and burial of superficial rocks. Heterogeneous crustal thickening induced by thrusting is expected to cause uplift, and removal of the overburden by localised high erosion rates (e.g. England \& Molnar, 1990; Platt, 1993). This is in agreement with the limited occurrence of syntectonic immature detrital sedimentary basins, which suggests that erosion likely played a role in exhumation.

Following peak P conditions, clockwise P-T paths in amphibolites and granulites of the study area frequently display alternating segments with a negative $\mathrm{dP} / \mathrm{dT}$, and segments of near-isothermal decompression. Negative $\mathrm{dP} / \mathrm{dT}$ paths require a low exhumation rate relative to the thermal relaxation rate of the thickened crust (England \& Thompson, 1984). Contrastingly, near isothermal decompression reflects a deflection of isotherms towards the surface and rapid exhumation due to tectonically-driven removal of the overburden (e.g. Duchêne et al., 1997). In modern orogenic belts, partially molten lowercrustal rocks are frequently exhumed in anatectic migmatite domes (Rey et al., 2001; Vanderhaeghe and Teyssier, 2001; Whitney et al., 2004; Vanderhaeghe et al., 2009) where they record supra-solidus isothermal decompression (e.g. Rey et al., 2009). These structures develop during the extensional gravitational collapse of the overthickened orogens, and provide an efficient tectonic mechanism to remove the overburden of lower-crustal rocks. Bulenga extensional shear zones (Fig. 14a, b). These structures are parallel to the trajectories of the early ubiquitous foliation S1 which, in the gneisses, carries high-grade mineral assemblages. The shear zones contain high strain rocks and form metamorphic breaks at the transition between migmatitic gneisses and low-grade metamorphic rocks (Fig. 14c). Such structures formed during high-grade metamorphism, and localised deformation during N-S directed stretching (D2). They accommodated the exhumation of the 
lower crust against rock units metamorphosed at shallower depths. Figure 14d shows the P-T paths of three rock samples of the Bole-Bulenga domain, two of them originating from the vicinity of the Bole SZ. Segments of the P-T paths which likely reflect tectonic exhumation during extension are identified and highlighted for two samples. Extension may not account for the exhumation of high grade rocks below $\sim 6$ kbar. Therefore, extension is probably significant, but it is not the only process responsible for the lower crust exhumation.

The thrust and the extensional shear zones are strongly overprinted by subsequent deformation (D3), consistent with east-west directed shortening (Fig. 14a, b). Pre-existent tectonic contacts, metamorphic gradients and isograds are folded and transposed into sub-vertical shear zones striking $\mathrm{N}$ to NE. Early fabrics (S1) are overprinted by a sub-vertical, penetrative schistose cleavage striking to the north (S3). Strong metamorphic gradients are observed across D3 shear zones and large (km-scale) folds. We argue that post-extension (D2) exhumation of high-grade rocks below 6 kbar occured during D3, in a crust dominated by a compressional to transpressional deformation during E-W shortening (Fig. 14d).

\section{Implications for Precambrian accretionary orogens.}

The Paleoproterozoic craton of NW Ghana displays a close association of high-grade metamorphic domains, comprising granulite- and amphibolite-facies rocks, juxtaposed with coeval low-grade largescale upper crustal slices. Our results provide evidence for metamorphic conditions which cannot be reconciled with a stable, steady-state, spatially and temporally homogeneous thermal regime. Furthermore, P-T paths displaying decompression at constant or increasing temperature cannot be interpreted as the result of homogeneous slow exhumation of a large orogenic domain with limited relief (Gapais et al., 2009). It rather argues for high exhumation rates, structurally-driven horizontal and vertical movements and differential exhumation in the crust, generating major lateral baric metamorphic gradients. Coupled metamorphic and structural data support the view that extensional detachments developed in a thickened, partially molten orogenic crust contributed to the exhumation of high-grade rocks. However, evidence for this crustal mechanical behaviour has not been reported from the Paleoproterozoic West African Craton so far, and evidence for extensional detachments are lacking in Precambrian accretionary orogens in general. 
The coexistence of metamorphic terranes recording diverse geothermal gradients implies the

existence of regional-scale heterogeneities in the thermal evolution of maturing crusts. Similar to modern orogens, the source of such thermo-mechanical variations may lie in the large-scale architecture of the Eburnean orogeny (Hyndman et al., 2005; Moresi et al., 2014), which remains an active research topic. The interpretations drawn from our results are supported by an increasing number of studies from other provinces, documenting metamorphic records which cannot be accounted for by a homogeneous geodynamic setting. Relics of high-P metamorphism are reported from the Minto Block, Canada, which was previously considered to be a very large and homogeneous high- $\mathrm{T}$, low-P granulite province (Percival and Skulski, 2000). Eclogites - high-pressure granulites reported from various Paleoproterozoic orogenic belts (e.g. Möller et al., 1995; Anderson et al., 2012) reflect a broadening range of tectonometamorphic environements at this period (Brown et al., 2007). Harley (1992) shows that the metamorphic record of Proterozoic granulites requires multiple geodynamic settings. It further demonstrates that significant variation in peak metamorphic pressure and in P-T paths are found within individual provinces. The complex metamorphic evolution of the Superior province has been interpreted as the result of the diachronous accretion of heterogeneous crustal fragments (Easton, 2000). Similarly, the existence of non-unique settings for Archean crustal growth and craton-building has been proposed by various authors, based on structural-metamorphic constraints (e.g. in the Yilgarn craton, Goscombe et al., 2009) or on geochemical arguments (e.g. Moyen et al., 2011, Bedard et al., 2013). The secular change of the Earth's thermal regime is well documented by the metamorphic record. The coexistence of distinct thermal environments is proposed to reflect the onset of some kind of plate tectonics (Brown, 2007, 2009 and refs. therein) during or after the Neoarchean. In this sense, we suggest that the metamorphic record of the West African Craton is representative of the geodynamic settings at work in a Paleoproterozoic ‘proto-plate tectonic regime’.

\section{CONCLUSION}

We recognise contrasting metamorphic patterns from juxtaposed tectono-metamorphic units in an interference zone between two craton-scale ductile shear zones, on the Paleoproterozoic West African craton, in NW Ghana. The range of metamorphic data illustrates heterogeneous thermal conditions in the juvenile crust at an early stage of the tectono-metamorphic evolution, prior to final accretion and thermal reequilibration. Strong lateral metamorphic gradients are interpreted to be the result of exhumation of the 
lower crust; and of the tectonic assembly of distinct crustal-scale slices, which underwent coeval evolutions at different depths. Extensional detachments localised deformation in a thickened, partially molten crust and contributed to the exhumation of high-grade rocks. The diversity of geothermal environments at the scale of the study area is consistent with the spatial variations in metamorphic conditions recorded across the southern West African Craton. The Paleoproterozoic craton in northwestern Ghana provides an exceptionally clear window showing the lower crust of the Eburnean orogen, and in this sense, it is key to the understanding of Eburnean geodynamics.

We interpret the metamorphic record of NW Ghana as being the product of a monocyclic orogenic evolution which brought in contact exhumed lower-crust with middle and upper crust. This view represents a working hypothesis which deserves testing in other regions of the West African Craton, in order to re-interpret the significance of metamorphism during the Eburnean orogeny. In any case, we suggest that the 'hot orogen' model, proposed to account for homogeneous, near isobaric metamorphic conditions across large domains recording low-dP/dT apparent geothermal gradients, is not the only model for Paleoproterozoic accretionary orogens.

\section{ACKNOWLEDGEMENTS}

775 We wish to gratefully acknowledge AMIRA International and the industry sponsors, including AusAid and the ARC Linkage Project LP110100667, for their support of the WAXI project (P934A). We acknowledge the facilities, and scientific and technical assistance of the Australian Microscopy \& Microanalysis Research Facility at the Centre for Microscopy, Characterization \& Analysis of UWA, a facility funded by the University, State and Commonwealth Governments. We thank the staff and facilities of the John De Laeter Centre for Isotope Research, hosted at Curtin University of Technology. Dominique Chardon is warmly thanked for sharing advice and constructive discussions which contributed to greatly improve the quality of the manuscript. Allen Kennedy is thanked for providing expertise with regards to SHRIMP dating. We recognise the logistical support and datasets provided by the Geological Survey Department of Ghana, as well as the chauffeurs from the IRD in Ouagadougou (Salifou Yougbaré, Boukary Ouedraogo and Matthieu Kaboré) and from the GSD of Ghana (Kwasi Duah). 
Abouchami, W., Boher, M., Michard, A. \& Albarede, F., 1990. A major 2.1 Ga event of mafic magmatism in West Africa; an early stage of crustal accretion. Journal of Geophysical Research, B, Solid Earth and Planets 95, 17, 605-617, 629.

Affaton, P., Sougy, J. \& Trompette, R., 1980. The tectono-stratigraphic relationships between the upper Precambrian and lower Paleozoic Volta Basin and the pan-african Dahomeyide orogenic belt (West Africa). American Journal of Science. 280, 3, 224-248.

Agyei Duodu, J., Loh, G.K., Boamah, K.O., Baba, M., Hirdes, W., Toloczyki, M. \& Davis, D.W., 2009. Geological map of Ghana 1:1 000 000. Geological Survey Department of Ghana (GSD).

Allibone, A., McCuaig, T.C., Harris, D., Etheridge, M., Munroe, S. \& Byrne, D., 2002. Structural controls on gold mineralization at the Ashanti Gold Deposit, Obuasi, Ghana. Society of Economic Geologists (Special Publication) 9, 65-93.

Anderson, J. R., Payne, J. L., Kelsey, D. E., Hand, M., Collins, A. S. \& Santosh, M., 2012. High-pressure granulites at the dawn of the Proterozoic. Geology, 40, 5, 431-434.

Arnould, M., 1961. Etude géologique des migmatites et des granites précambriens du nord-est de la Côte d’Ivoire et de la Haute-Volta méridionale. Mémoires du BRGM, 176pp.

Arzi, A. A., 1978. Critical phenomena in the rheology of partially melted rocks. Tectonophysics, 44, 1, $810 \quad 173-184$.

Attoh, K., Evans, M. J. \& Bickford, M. E., 2006. Geochemistry of an ultramafic-rodingite rock association in the Paleoproterozoic Dixcove greenstone belt, southwestern Ghana. Journal of African Earth Sciences, 45, 333-346.

Auzanneaun, E., Schmidt, M.W., Vielzeuf, D. \& Connolly, J.A.D., 2010. Titanium in phengite: a geobarometer for high temperature eclogites. Contributions to Mineralogy and Petrology 159, 1-24.

Baratoux, L., Metelka, V., Naba, S., Jessell, W.M., Gregoire, M. \& Ganne, J., 2011. Juvenile paleoproterozoic crust evolution during the Eburnean orogeny (-2.2-2.0 Ga), western Burkina Faso. Precambrian Research, 191, 18-45.

Bard, J.P. \& Lemoine, S., 1976. Phase tectoniques superposes dans les métasédiments précambriens du domaine côtier occidental de la Côte-d’Ivoire. Precambrian Research, 3, 209-229.

825 Berman, RG., 1991. Thermobarometry using multi-equilibrium calculations: a new technique, with petrological applications. Canadian Mineralogist, 29, 833-855.

Block, S., Moyen, J. F., Zeh, A., Poujol, M., Jaguin, J. \& Paquette, J.-L., 2013. The Murchison greenstone belt, South Africa: accreted slivers with contrasting metamorphic conditions. Precambrian Research, 227, 77-98.

Brown, M., 2009. Metamorphic patterns in orogenic systems and the geological record. In: Cawood PA, Kroner A (eds) Earth accretionary systems in space and time. The Geological Society, London, Special Publications, 318, 37-74

835 Brown, M., 2007. Metamorphic conditions in orogenic belts: a record of secular change. International Geology Review, 49, 193-234

Brown, M., 2002. Retrograde processes in migmatites and granulites revisited. Journal of. Metamorphic Geology., 20, 25-40.

840 Brown, M., Averkin, Y.A., McLellan, E.L. \& Sawyer, E.W., 1995. Melt segregation in migmatites. Journal of Geophysical Research: Solid Earth, 100, B8, 15 655-15 679.

Boher, M., Abouchami, W., Michard, A., Albarède, F. \& Arndt, N. T., 1992. Crustal growth in West Africa at 2.1 Ga. Journal of Geophysical Research: Solid Earth, 97, B1, 345-369.

Bohlen, S.R., \& Liotta, J.J., 1986. A barometer for garnet amphibolites and garnet granulites. Journal of Petrology, 27, 1025-1034. 
Bonhomme, M., 1962. Contribution à l'etude geochronologique de la plate-forme de l'Ouest Africain. Annals de la Faculte des Sciences de Universite de Clermont- Ferrand. Geologie Minerale 5, 62.

Burov, E., \& Yamato, P., 2008. Continental plate collision P-T-t-z conditions and unstable vs. stable plate dynamics: Insights from thermo-mechanical modelling. Lithos, 103, 178-204.

855 Caby, R., Delor, C. \& Agoh, O., 2000. Lithology, structure and metamorphism of the Birimian formations in the Odienné area (Ivory Coast): the major role played by plutonic diapirism and strike-slip faulting at the border of the Man Craton. Journal of African Earth Sciences, 30, 351-374.

Cagnard, F., Gapais, D. \& Barbey, P., 2007. Collision tectonics involving juvenile crust: the example of the southern Finnish Svecofennides. Precambrian Research, 154, 125-141.

Cagnard, F., Durrieu, N., Gapais, D., Brun, J. P. \& Ehlers, C., 2006. Crustal thickening and lateral flow during compression of hot lithospheres, with particular reference to Precambrian times. Terra Nova, 18(1), 72-78.

Carrington, D.P., \& Watt, G.R., 1995. A geochemical and experimental study of the role of K-feldspar during water-undersaturated melting of metapelites. Chemical Geology, 122, 59-76.

Cawood, P. A., Kröner, A., Collins, W. J., Kusky, T. M., Mooney, W. D. \& Windley, B. F., 2009. Accretionary orogens through Earth history. Geological Society, London, Special Publications, 318, 1-36.

Chardon, D., Jayananda, M. \& Peucat, J. J., 2011. Lateral constrictional flow of hot orogenic crust: Insights from the Neoarchean of south India, geological and geophysical implications for orogenic plateaux. Geochemistry, Geophysics, Geosystems, 12.

Chardon, D., Gapais, D. \& Cagnard, F., 2009. Flow of ultra-hot orogens: a view from the Precambrian, clues for the Phanerozoic. Tectonophysics, 477, 105-118.

Chardon, D., \& Jayananda, M., 2008. Three-dimensional field perspective on deformation, flow, and growth of the lower continental crust (Dharwar craton, India). Tectonics, 27.

Coggon, R. \& Holland, T.J.B., 2002. Mixing properties of phengitic micas and revised garnet-phengite thermobarometers. Journal of Metamorphic Geology, 20, 683-96.

Condie, K. C., 1998. Episodic continental growth and supercontinents: a mantle avalanche connection?

Earth and Planetary Science Letters, 163, 1, 97-108.

Connolly, J. A. D., 2005. Computation of phase equilibria by linear programming : A tool for geodynamic modeling and its application to subduction zone decarbonation. Earth and Planetary Science Letters, 236, 524-541.

Connolly, J.A.D. \& Petrini, K., 2002. An automated strategy for calculation of phase diagram sections and retrieval of rock properties as a function of physical conditions. Journal of Metamorphic Geology, 20, 697-708.

Dale, J., Powell, R., White, R.W., Elmer, F.L. \& Holland, T.J.B. 2005. A thermodynamic model for Ca895 Na clinoamphiboles in $\mathrm{Na}_{2} \mathrm{O}-\mathrm{CaO}-\mathrm{FeO}-\mathrm{MgO}-\mathrm{Al}_{2} \mathrm{O}_{3}-\mathrm{SiO}_{2}-\mathrm{H}_{2} \mathrm{O}-\mathrm{O}$ for petrological calculations. Journal of Metamorphic Geology, 23, 771-91.

Dampare, S.B., Shibata, T., Asiedu, D.K., Osae, S. \& Banoeng-Yakubo, B., 2008. Geochemistry of Paleoproterozoic metavolcanic rocks from the southern Ashanti volcanic belt Ghana: Petrogenetic and tectonic setting implications. Precambrian Research 162, 403-423.

Davis, D.W., Hirdes, W., Schaltegger, U. \& Nunoo, E.A., 1994. U-Pb age constraints on deposition and provenance of Birimian and gold-bearing Tarkwaian sediments in Ghana West Africa. Precambrian Research, 67, 89-107. 

Metamorphic Geology, 24, 655-668.

De Capitani, C. \& Brown, T.H., 1987. The computation of chemical equilibria in complex systems containing non-ideal solutions. Geochimica et Cosmochimica Acta, 51, 2639-2652.

De Kock, G.S. Theveniaut, H., Botha, P.W. \& Gyapong, W., 2012. Timing the structural events in the Palaeoproterozoic Bolé-Nangodi belt terrane and adjacent Maluwe basin, West African craton, in centralwest Ghana. Journal of African Earth Sciences, 65, 1-24.

De Kock, G.S., Armstrong, R.A., Siegfried, H.P. \& Thomas, E., 2011. Geochronology of the Birim Supergroup of the West African craton in the Wa-Bolé region of central-west Ghana: implications for the stratigraphic framework. Journal of African Earth Sciences, 59, 1-40.

De Kock, G.S. Theveniaut, H., Botha, P.W. \& Gyapong, W., 2009. Geological map explanation—map sheet 0803B (1:100,000). CGS/BRGM/Geoman. Geological Survey Department of Ghana.

920 Debat, P., Nikiema, S., Mercier, A., Lompo, M., Beziat, D., Bourges, F., Roddaz, M., Salvi, S., Tollon, F. \& Wenmenga, U. A., 2003. New metamorphic constraint for the Eburnean orogeny from Paleoproterozoic formations of the Man shield (Aribinda and Tampelga countries, Burkina Faso) : Precambrian Research, 123, 47-65.

Diener, J. F. A., \& Powell, R., 2012. Revised activity-composition models for clinopyroxene and amphibole. Journal of Metamorphic Geology, 30, 2, 131-142.

Diener, J. F. A., Powell, R., White, R. W., \& Holland, T. J. B., 2007. A new thermodynamic model for clino-and orthoamphiboles in the system $\mathrm{Na}_{2} \mathrm{O}-\mathrm{CaO}-\mathrm{FeO}-\mathrm{MgO}-\mathrm{Al}_{2} \mathrm{O}_{3}-\mathrm{SiO}_{2}-\mathrm{H}_{2} \mathrm{O}-\mathrm{O}$. Journal of Metamorphic Geology, 25, 6, 631-656.

Dubacq, B., Vidal, O. \& De Andrade, V., 2010. Dehydration of dioctahedral aluminous phyllosilicates:thermodynamic modelling and implications for thermobarometric estimates. Contributions to Mineralogy and Petrology. 159,159-174.

Duchêne, S., Lardeaux, J. M., \& Albarède, F., 1997. Exhumation of eclogites: insights from depth-time path analysis. Tectonophysics, 280(1), 125-140.

Easton, R. M., 2000. Metamorphism of the Canadian Shield, Ontario, Canada. I. The Superior Province. The Canadian Mineralogist, 38, 287-317.

Egal, E., Thieblemont, D., Lahondere, D., Guerrot, C., Costea, C.A., Iliescu, D., Delor, C., Goujou, J.-C., 940 Lafon, J.M. \& Tegyey, M., 2002. Late Eburnean granitization and tectonics along the western and northwestern margin of the Archean Kenema- Man domain (Guinea West African Craton). Precambrian Research, 117, 57-84.

Eisenlohr, B.N. \& Hirdes, W., 1992. The structural development of the early Proterozoic Birimian and Tarkwaian rocks of southwest Ghana, West Africa. Journal of African Earth Sciences, 14, 313-325.

England, P. C., \& Thompson, A. B., 1984. Pressure-temperature-time paths of regional metamorphism I. Heat transfer during the evolution of regions of thickened continental crust. Journal of Petrology, 25, 894-928.

England, P., \& Molnar, P., 1990. Surface uplift, uplift of rocks, and exhumation of rocks. Geology, 18, 1173-1177.

Evans, T. P., 2004. A method for calculating effective bulk composition modification due to crystal 955 fractionation in garnetbearing schist: implications for isopleth thermobarometry. Journal of Metamorphic Geology, 22, 547-557.

Feybesse, J.-L., Billa, M., Guerrit, C., Duguey, E., Lescuyer, J.-L., Milesi, J.P. \& Bouchot, V., 2006. The paleoproterozoic Ghanaian province : Geodynamic model and ore controls, including regional stress 
modeling. Precambrian Research, 149, 149-196.

Feybesse, J.L., 1990. The Bororno-Goren lower proterozoic “belt” (Burkina-Faso): an example of interference between two Eburnean transcurrent phases. Comptes Rendus - Academie des Sciences. Geoscience 310 (serie II), 1353-1360.

965 Fletcher, I. R., McNaughton, N. J., Davis, W. J. \& Rasmussen, B., 2010, Matrix effects and calibration limitations in ion probe $\mathrm{U}-\mathrm{Pb}$ and $\mathrm{Th}-\mathrm{Pb}$ dating of monazite. Chemical Geology, 270, 31-44.

Foster, G., Kinny, P., Vance, D., Prince, C. \& Harris, N., 2000, The significance of monazite U-Th-Pb age data in metamorphic assemblages; a combined study of monazite and garnet chronometry. Earth and Planetary Science Letters, 181, 327-340.

Galipp, K., Klemd, R. \& Hirdes, W., 2003. Metamorphism and geochemistry of the Paleoproterozoic Birimian Sefwi volcanic belt (Ghana, West Africa). Geologisches Jahrbuch 111, 151-191.

Ganne, J., De Andrade, V., Weinberg, R., Dubacq, B., Vidal, O. and Kagambega, N., Naba, S., Baratoux, 975 L., Jessell, M. \& Allibon, J., 2012. Modern-style plate subduction preserved in the Palaeoproterozoic West African Craton : Nature Geoscience, 5, 60-65.

Gapais, D., Cagnard, F., Gueydan, F., Barbey, P. \& Ballevre, M., 2009. Mountain building and exhumation processes through time: inferences from nature and models. Terra Nova, 21, 188-194.

980 Gapais, D., Pelletier, A., Ménot, R. P. \& Peucat, J. J., 2008. Paleoproterozoic tectonics in the Terre Adélie Craton (East Antarctica). Precambrian Research, 162, 531-539.

Gasquet, D., Bertrand, J. M., Paquette, J. L., Lehmann, J., Ratzov, G., Guedes, R. D. A. \& Nomade, S., 2010. Miocene to Messinian deformation and hydrothermal activity in a pre-Alpine basement massif of the French western Alps: new U-Th-Pb and argon ages from the Lauzière massif. Bulletin de la Société Géologique de France, 181, 227-241.

Gasquet, D., Barbey, P., Adou, M. \& Paquette, J.L., 2003. Structure Sr-Nd isotope geochemistry and zircon U-Pb geochronology of the granitoids of the Dabakala area (Cote d'Ivoire): evidence for a $2.3 \mathrm{Ga}$ crustal growth event in the Palaeoproterozoic of West Africa? Precambrian Research, 127, 329-354.

Gerdes, A. \& Zeh, A., 2009. Zircon formation versus zircon alteration-new insights from combined U$\mathrm{Pb}$ and $\mathrm{Lu}-\mathrm{Hf}$ in-situ LA-ICP-MS analyses, and consequences for the interpretation of Archean zircon from the Central Zone of the Limpopo Belt. Chemical Geology, 261, 230-243.

Gerdes, A. \& Zeh, A., 2006. Combined U-Pb and Hf isotope LA-(MC-) ICP-MS analyses of detrital zircons: comparison with SHRIMP and new constraints for the provenance and age of an Armorican metasediment in Central Germany. Earth and Planetary Science Letters, 249, 47-61.

1000 Goscombe, B., Blewett, R., Czarnota, K., Maas, R. \& Groenewald, B, 2009. Metamorphic evolution and integrated terrane analysis of the eastern Yilgarn Craton: rationale, methods, outcomes and interpretation. Geoscience Australia, Record 2009/23. 270pp.

Green, E., Holland, T. \& Powell, R., 2007. An order-disorder model for omphacitic pyroxenes in the system jadeite-diopside-hedenbergite-acmite, with applications to eclogitic rocks. American Mineralogist, 92, 1181-1189.

Hein, K.A.A., 2010. Succession of structural events in the Goren greenstone belt (Burkina Faso): implications for West African tectonics. Journal of African Earth Sciences, 56, 83-94.

Hirdes, W., Davis, D.W., Ludtke, G. \& Konan, G., 1996. Two generations of Birimian (Paleoproterozoic) volcanic belts in northeastern Cote d'Ivoire (West Africa): consequences for the 'Birimian controversy. Precambrian Research, 80, 173-191. 
Holland, T., Baker, J. \& Powell, R., 1998. Mixing properties and activity-composition relationships of chlorites in the system MgO-FeO- $\mathrm{Al}_{2} \mathrm{O}_{3}-\mathrm{SiO}_{2}-\mathrm{H}_{2} \mathrm{O}$. European Journal of Mineralogy 10, 395-406.

1020 Horstwood, M. S., Foster, G. L., Parrish, R. R., Noble, S. R. \& Nowell, G. M., 2003. Common-Pb corrected in situ $\mathrm{U}-\mathrm{Pb}$ accessory mineral geochronology by LA-MC-ICP-MS. Journal of Analytical Atomic Spectrometry, 18, 837-846.

Hyndman, R. D., Currie, C. A., \& Mazzotti, S. P., 2005. Subduction zone backarcs, mobile belts, and orogenic heat. GSA Today, 15, 4-10.

Jackson, S. E., Pearson, N. J., Griffin, W. L., \& Belousova, E. A., 2004. The application of laser ablationinductively coupled plasma-mass spectrometry to in situ $\mathrm{U}-\mathrm{Pb}$ zircon geochronology. Chemical Geology, 211, 47-69.

John, T., Klemd, R., Hirdes, W. \& Loh, G., 1999. The metamorphic evolution of the Pale-oproterozoic (Birimian) volcanic Ashanti belt (Ghana, West Africa). Precambrian Research, 98, 11-30.

Johnson, T. E., White, R. W. \& Powell, R., 2008. Partial melting of metagreywacke: a calculated mineral equilibria study. Journal of Metamorphic Geology, 26, 8, 837-853.

Johnson, T. \& Brown, M., 2004. Quantitative Constraints on Metamorphism in the Variscides of Southern Brittany - a Complementary Pseudosection Approach. Journal of Petrology. 45, 6. 1237-1259.

Karlstrom, K. E., Åhäll, K. I., Harlan, S. S., Williams, M. L., McLelland, J. \& Geissman, J. W., 2001.

Long-lived (1.8-1.0 Ga) convergent orogen in southern Laurentia, its extensions to Australia and Baltica, and implications for refining Rodinia. Precambrian Research, 111, 5-30.

1040 Kennedy, A. \& Kinny, P. D., (2004 Identifying inter- and intra-laboratory SIMS monazite standards. SHRIMP workshop, Hiroshima, Japan, 11-14.

Klemd, R., Hunken, U. \& Olesch, M., 2002. Metamorphism of the country rocks hosting gold-sulfidebearing quartz veins in the Paleoproterozoic southern Kibi- Winneba belt (SE-Ghana). Journal of African Earth Sciences, 35, 199-211.

Kouamelan, A.N., Delor, C. \& Peucat, J.-J., 1997. Geochronological evidence for reworking of Archaean terranes during the Early Proterozoic (2.1 Ga) in the western Côte d'Ivoire (Man Rise - West African Craton). Precambrian Research, 86, 177-199.

Kouamelan, A. N., 1996. Géochronologie et Géochimie des Formations Archéennes et Protérozoïques de la Dorsale de Man en Côte d'Ivoire. Implications pour la Transition Archéen-Protéozoïque (Doctoral dissertation, Université Rennes 1).

Kitson, A.E., 1918. Ann. Report. Gold Coast Geological Survey for 1916/17, Accra. (non publ.), Accra.

Kretz, R., 1983. Symbols of rock-forming minerals. American Mineralogist, 68, 277-279.

Kriebek, B., Sykorová, I., Machovic, V. \& Laufek, F., 2008. Graphitization of organic matter and fluiddeposited graphite in Palaeoproterozoic (Birimian) black shales of the Kaya-Goren greenstone belt (Burkina Faso West Africa). Journal of Metamorphic Geology, 26, 937-958.

Laurent, O., Martin, H., Doucelance, R., Moyen, J. F. \& Paquette, J. L., 2011. Geochemistry and petrogenesis of high-K "sanukitoids" from the Bulai pluton, Central Limpopo Belt, South Africa: Implications for geodynamic changes at the Archaean-Proterozoic boundary. Lithos, 123, 73-91.

Le Breton, N., \& Thompson, A.B., 1988. Fluid-absent (dehydration) melting of biotite in metapelites in the early stages of crustal anatexis. Contributions to Mineralogy and Petrology, 99, 226-237.

Ledru, P., Pons, J., Milesi, J.P., Feybesse, J.L. \& Johan, V., 1991. Transcurrent tectonics and polycyclic evolution in the lower Proterozoic of Senegal-Mali. Precambrian Research, 50, 337-354.

Lemoine, S., Tempier, P., Bassot, J.P., Caen-Vachette, M. \& Vialette, Y., 1990. The Burkinian orogenic 
Leube, A., Hirdes, W., Mauer, R. \& Kesse, G.O., 1990. The early Proterozoic Birimian Supergroup of Ghana and some aspects of its associated gold mineralization. Precambrian Research, 46, 139-165.

1080 Liégeois, J.P., Claessens, W., Camara, D. \& Klerkx, J., 1991. Short-lived Eburnian orogeny in southern Mali. Geology, tectonics, U-Pb and Rb-Sr geochronology. Precambrian Research 50, 111-136.

Lompo, M., 2009. A model of subsidence of an oceanic plateau magmatic rocks in the Man-Leo Shield of the West African Craton Geodynamic evolution of the 2.25-2.0 Ga Palaeoproterozoic. In: Reddy, S.M.,

1085 Mazumder, R. \& Evans, D.A.D., Collins, A.S. (Eds.), Palaeoproterozoic Supercontinents and Global Evolution. Geological Society, London, pp. 231-254.

Ludwig, K.R., 2001. Isoplot/Ex, rev. 2.49: a geochronological toolkit for Microsoft Excel. Berkeley Geochronology Center, Special Publication, 4, 55 p.

Martin, H., Smithies, R. H., Rapp, R., Moyen, J. F. \& Champion, D., 2005. An overview of adakite, tonalite-trondhjemite-granodiorite (TTG), and sanukitoid: relationships and some implications for crustal evolution. Lithos, 79, 1-24.

1095 Marmo, B.A., Clarke, G.L. \& Powell, R., 2002. Fractionation of bulk rock composition due to porphyroblast growth : effects on eclogite facies mineral equilibria, Pam Peninsula, New Caledonia. Journal of Metamorphic Geology, 20, 151-165.

Massonne, H. J. \& Willner, A. P., 2008. Phase relations and dehydration behaviour of psammopelite and mid-ocean ridge basalt at very-low-grade to low-grade metamorphic conditions. European Journal of Mineralogy, 20, 5, 867-879.

Melcher, F., 1995. Genesis of chemical sediments in Birimian greenstone belts: evidence from gondites and related manganese-bearing rocks from northern Ghana. Mineralogical Magazine, 59, 229-251.

Melcher, F. \& Stumpfl, E.F., 1994. Palaeoproterozoic Exhalite Formation in Northern Ghana; Source of Epigenetic Gold-Quartz Vein Mineralization? Geologisches Jahrbuch, 100, 201-246.

Metelka, V., Baratoux, L., Naba, S. \& Jessell, W.M., 2011. A geophysically constrained litho-structural analysis of the Eburnean greenstone belts and associated granitoid domains, western Burkina Faso. Precambrian Research, 190, 48-69.

Milesi, J.P., Feybesse, J.L., Pinna, P., Deschamps, Y., Kampunzu, H., Muhongo, S., Lescuyer, J.L., Le Goff, E., Delor, C., Billa, M., Ralay, F. \& Heinry, C., 2004. Geological map of Africa 1:10,000,000, SIGAfrique project. In: 20th Conference of African Geology, BRGM, Orleans, France, 2-7 June,

1115 http://www.sigafrique.net.

Milesi, J.-P., Ledru, P. \& Feybesse, J.-L., Dommanget, A., Marcoux, E., 1992. Early Proterozoic ore deposits and tectonics of the Birimian orogenic belt West Africa. Precambrian Research, 58, 305-344.

1120 Milési, J.P., Feybesse, J.L., Ledru, P., Dommanget, A., Ouedraogo, M.F., Marcoux, E., Prost, A., Vinchon, C., Sylvain, J.P., Johan, V., Tegyey, M., Calvez, J.Y. \& Lagny, Ph., 1989. Minéralisations aurifères de l'Afrique de l'ouest, leurs relations avec l'évolution litho-structurale au Protérozoïque inférieur. Carte géologique au 1/2.000.000. Chronique de la recherche minière, 497, 3-98.

1125 Millonig, L., Zeh, A., Gerdes, A., Klemd, R. \& Barton, J.M., 2010. Decompressional Heating of the Mahalapye Complex (Limpopo Belt, Botswana): a Response to Palaeoproterozoic Magmatic Underplating ? Journal of Petrology, 51, 3, 703-729.

Möller, A., Appel, P., Mezger, K. \& Schenk, V., 1995. Evidence for a 2 Ga subduction zone: eclogites in the Usagarian belt of Tanzania, Geology 23, 1067-1070.

Moresi, L., Betts, P. G., Miller, M. S., \& Cayley, R. A., 2014. Dynamics of continental accretion. Nature, 508, 245-248.

Moyen, J. F., 2011. The composite Archaean grey gneisses: petrological significance, and evidence for a non-unique tectonic setting for Archaean crustal growth. Lithos, 123, 21-36. 
Naba, S., Lompo, M., Debat, P., Bouchez, J.L. \& Beziat, D., 2004. Structure and emplacement model for late-orogenic Paleoproterozoic granitoids: the Tenkodogo-Yamba elongated pluton (Eastern Burkina Faso). Journal of African Earth Sciences, 38, 41-57.

Newton, R.C., Charlu, T.V. \& Kleppa, O.J., 1980. Thermochemistry of the high structural state plagioclases. Geochemica Cosmochimica Acta, 44, 933-941.

Ndiaye, P.M., Robineau, B. \& Moreau, C., 1989. Déformation et métamorphisme des formations birrimiennes en relation avec la mise en place du granite éburnéen de Saraya (Sénégal oriental). Bulletin de la Société Géologique de France, 8, 3, 619-625.

Oberthür, T., Vetter, U., Davis, D.W. \& Amanor, J.A., 1998. Age constraints on gold mineralization and Paleoproterozoic crustal evolution in the Ashanti belt of southern Ghana. Precambrian Research, 89, 129-143.

Opare-Addo, E., Browning, P. \& John, B.E., 1993. Pressure-temperature constraints on the evolution of an Early Proterozoic plutonic suite in southern Ghana, West Africa. Journal of African Earth Sciences, 17, 51, 13-22.

Parra, T., Vidal, O. \& Agard, P., 2002. A Thermodynamic model for Fe-Mg dioctahedral K-white micas using data from phase equilibrium experiments and natural pelitic assemblages. Contributions to Mineralogy and Petrology. 143, 706-732.

Patiño Douce, A.E. \& Harris, N., 1998. Experimental constraints on Himalayan anatexis. Journal of Petrology, 39, 689-710.

1160 Patisson, D.R.M., De Capitan, C. \& Gaidies, F., 2011. Petrological consequences of variations in metamorphic reaction affinity. Journal of Metamorphic Geology, 29, 953-977.

Percival, J. A. \& Skulski, T., 2000. Tectonothermal evolution of the northern Minto Block, Superior Province, Quebec, Canada. The Canadian Mineralogist, 38, 345-378.

Percival, J. A., Mortensen, J. K., Stern, R. A., Card, K. D. \&Bégin, N. J., 1992. Giant granulite terranes of northeastern Superior Province: the Ashuanipi complex and Minto block. Canadian Journal of Earth Sciences, 29, 2287-2308.

1170 Perrouty, S., Aillères, L., Jessell, M. W., Baratoux, L., Bourassa, Y. \& Crawford, B., 2012. Revised Eburnean geodynamic evolution of the gold-rich southern Ashanti Belt, Ghana, with new field and geophysical evidence of pre-Tarkwaian deformations. Precambrian Research, 204- 205, 12- 39.

Pitra, P., Kouamelan, A.N., Ballèvre, M. \& Peucat, J-J., 2010. Palaeoproterozoic high-pressure granulite overprint of Archean continental crust : evidence for homogeneous crustal thickening (Man Rise, Ivory Coast). Journal of Metamorphic Geology, 28, 41-58.

Platt, J. P., 1993. Exhumation of high-pressure rocks: A review of concepts and processes. Terra nova, 5, 119-133.

Pons, J., Barbey, P., Dupuis, D. \& Leger, J.M., 1995. Mechanisms of pluton emplacement and structural evolution of a 2.1 Ga juvenile continental crust: the Birimian of southwestern Niger. Precambrian Research, 70, 281-301.

1185 Pouclet, A., Vidal, M., Delor, C., Simeon, Y. \& Alric, G., 1996. Le volcanisme birimien du nord-est de la Cote-d'Ivoire mise en evidence de deux phases volcanotectoniques distinctes dans l'evolution geodynamique du Paleoproterozoique. Bulletin de la Societe Geologique de France, 167, 529-541.

Powell, R. \& Holland, T., 2010. Using equilibrium thermodynamics to understand metamorphism and metamorphic rocks. Elements. 6, 309-314.

Powell, R., Holland, T., Worley, B., 1998. Calculating phase diagrams involving solid solutions via nonlinear equations, with examples using THERMOCALC. Journal of Metamorphic Geology, 16, 577-588. 
1195 Rasmussen, B., Fletcher, I. R., and McNaughton, N. J., 2001, Dating low-grade metamorphic events by SHRIMP U-Pb analysis of monazite in shales. Geology, 29, 963-966.

Rasmussen, B., Bengtson, S., Fletcher, I. R. \& McNaughton, N. J., 2002, Discoidal Impressions and Trace-Like Fossils More Than 1200 Million Years Old. Science, 296, 1112-1115.

Rasmussen, B., Fletcher, I. R., Muhling, J. R. \& Wilde, S. A., 2010, In situ U-Th-Pb geochronology of monazite and xenotime from the Jack Hills belt: implications for the age of deposition and metamorphism of Hadean zircons. Precambrian Research, 180, 26-46.

1205 Rey, P. F., Teyssier, C., Whitney, D. L., 2009. Extension rates, crustal melting, and core complex dynamics. Geology, 37, 391-394.

Rey, P. F., Vanderhaeghe, O. \& Teyssier, C. 2001. Gravitational collapse of the continental crust: definitions, regimes and modes. Tectonophysics, 342, 435-449

Roques, M., 1948. Le Précambrien de l'Afrique occidentale française. Bulletin de la Societe Geologique de France, 15, 8-9, 528-546.

Ruschel, K., Nasdala, L., Kronz, A., Hanchar, J., Többens, D. M., Škoda, R., Finger, F. \& Möller, A., 1215 2012, A Raman spectroscopic study on the structural disorder of monazite-(Ce). Mineralogy and Petrology., 105, 41-55.

Sagatzky, J., 1954. La Géologie et les ressources minières de la Haute-Volta méridionale. Grande Imprimeria africaine.

Sandiford, M., 1989. Horizontal structures in granulite terranes: A record of mountain building or mountain collapse?. Geology, 17, 449-452.

Sawyer, E.W., 1994. Melt segregation in the continental crust. Geology, 22, 1019-1022.

Schmitz, S., Möller, A., Wilke, M., Malzer,W., Kanngiesser, B., Bousquet, R., Berger, A. \& Schefer, S., 2009, Chemical U-Th-Pb dating of monazite by 3D-Micro X-ray fluorescence analysis with synchrotron radiation. European Journal of Mineralogy, 21, 927-945.

1230 Siegfried, P., Clarke, B., Agenbacht, A., Delor, C., Grantham, G., De Kock, G.S. \& Van Rooyen, R.C., 2009. Geological map explanation—map sheet 0903D (1:100,000). CGS/BRGM/Geoman. Geological Survey Department of Ghana (GSD).

Soumaila, A. \& Garba, Z., 2006. Le métamorphisme des formations de la ceinture de roches vertes 1235 birimienne (paléoprotérozoïque) de Diagorou-Darbani (Liptako, Niger, Afrique de l'Ouest). Africa Geoscience Review, 13, 1, 116-128.

Stacey, J. T. \& Kramers, 1975. Approximation of terrestrial lead isotope evolution by a two-stage model. Earth and Planetary Science Letters, 26, 207-221.

Stevens, G. \& Moyen, J. F., 2007. Metamorphism in the Barberton Granite Greenstone Terrane: A Record of Paleoarchean Accretion. Developments in Precambrian Geology, 15, 669-698.

Stöckhert, B., \& Gerya, T. V., 2005. Pre-collisional high pressure metamorphism and nappe tectonics at active continental margins: a numerical simulation. Terra Nova, 17, 102-110.

Tagini, B., 1971. Esquisse structurale de la Cote d’Ivoire. In: Essai de geotectonique regionale. Université de Lausanne, 302 p.

1250 Tajčmanová, L., Connolly, J.A.D. \& Cesare, B. 2009. A thermodynamic model for titanium and ferric iron solution in biotite. Journal of Metamorphic Geology, 27, 153-64.

Taylor, P.N., Moorbath, S., Leube, A. \& Hirdes, W., 1992. Early Proterozoic crustal evolution in the birimian of Ghana: constraints from geochronology and isotope geochemistry. Precambrian Research 56, 97-111. 
Tshibubudze, A., Hein, K.A.A. \& Marquis, P., 2009. The Markoye shear zone in NE Burkina Faso. Journal of African Earth Sciences, 55, 245-256.

1260

1265

1270

1275

1280 Vanderhaeghe, O., Ledru, P., Thiéblemont, D., Egal, E., Cocherie, A., Tegyey, M. \& Milési, J. P., 1998.

Contrasting mechanism of crustal growth: Geodynamic evolution of the Paleoproterozoic granitegreenstone belts of French Guiana. Precambrian Research, 92, 165-193.

Vidal, M., Gumiaux, C., Cagnard, F., Pouclet, A., Ouattara, G. \& Pichon, M., 2009. Evolution of a

1285 Paleaoproterozoic « weak type » orogeny in the West African Craton (Ivory Coast). Tectonophysics 477, 145-159.

Vidal, M., Delor, C., Pouclet, A., Simeon, Y. \& Alric, G., 1996. Evolution geodynamique de l’Afrique de l’Ouest entre 2,2 Ga et $2 \mathrm{Ga}$; le style "archeen" des ceintures vertes et des ensembles sedimentaires birimiens du nord-est de la Cote-d’Ivoire. Bulletin de la Societe Geologique de France, 167, 307-319.

1290

Vidal, M. \& Alric, G., 1994. The Palaeoproterozoic (Birimian) of Haute-Comoe in the West African craton Ivory Coast: a transtensional back-arc basin. Precambrian Research, 65, 207-229.

Vidal, M., Prost A, Alric, G. \& Lemoine, S., 1992. Présence d’un socle antérieur à une suture océanique du Birimien inférieur en Côte d'Ivoire (Afrique de l'Ouest). Compte-rendu de l'Académie des Sciences, 315, II, 193-200.

Vidal, O., DeAndrade, V., Lewin, E., Munoz, M., Parra, T. \& Pascarelli, S., 2006. P-T-deformation$\mathrm{Fe} 3+/ \mathrm{Fe} 2+$ mapping at the thin section scale and comparison with XANES mapping. Application to a garnet-bearing metapelite from the Sambagawa metamorphic belt (Japan). Journal of Metamorphic Geology, 24, 669-683.

1300 Vidal, O., Parra, T. \& Trotet, F., 2001. A thermodynamic model for Fe-Mg aluminous chlorite using data from phase equilibrium experiments and natural pelitic assemblages in the $100-600{ }^{\circ} \mathrm{C}, 1-25 \mathrm{kbar}$ P-T range. American Journal of Science. 301, 557-592.

Vidal, O. \& Parra, T., 2000. Exhumation paths of high pressure metapelites obtained from local equilibria for chlorite-phengite assemblages. Geological Journal, 35, 139-161.

1305 Waldbaum, D.R. \& Thompson, J.B. 1968. Mixing Properties of Sanidine Crystalline Solutions .2. Calculations Based On Volume Data. American Mineralogist, 53.

White, R. W. \& Powell, R., 2002. Melt loss and the preservation of granulite facies mineral assemblages. Journal of Metamorphic Geology, 20, 621-632. 

139-153.

White, R.W., Powell, R., Holland, T.J.B. \& Worley, B.A., 2000. The effect of $\mathrm{TiO}_{2}$ and $\mathrm{Fe}_{2} \mathrm{O}_{3}$ on metapelitic assemblages at greenschist and amphibolite facies conditions: mineral equilibria calculations in the system $\mathrm{K}_{2} \mathrm{O}-\mathrm{FeO}-\mathrm{MgO}-\mathrm{Al}_{2} \mathrm{O}_{3}-\mathrm{SiO}_{2}-\mathrm{H}_{2} \mathrm{O}-\mathrm{TiO}_{2}-\mathrm{Fe}_{2} \mathrm{O}_{3}$. Journal of Metamorphic Geology, 18, 497511.

Whitney, D. L., Teyssier, C., Vanderhaeghe, O., 2004. Gneiss domes and crustal flow. Gneiss domes in orogeny, $\mathbf{3 8 0}, 15$. 2013. Geological Survey of Western Australia, Perth.

Yamato, P., Agard, P., Goffe, B., De Andrade, V., Vidal, O. \& Jolivet, L., 2007a. New, high-precision P$\mathrm{T}$ estimates for Oman blueschists: implications for obduction, nappe stacking and exhumation processes. Journal of Metamorphic Geology. 25, 657-682.

Yamato, P., Agard, P., Burov, E., Le Pourhiet, L., Jolivet, L., \& Tiberi, C., 2007b. Burial and exhumation in a subduction wedge: Mutual constraints from thermomechanical modeling and natural P-T-t data (Schistes Lustrés, western Alps). Journal of Geophysical Research: Solid Earth (1978-2012), 112(B7).

Zeh, A., Jaguin, J., Poujol, M., Boulvais, P., Block, S. \& Paquette, J.-L., 2013. Juvenile crust formation in the northeastern Kaapvaal Craton at $2.97 \mathrm{Ga}-$ Implications for Archean terrane accretion, and the source of the Pietersburg gold. Precambrian Research, 233, 20-43.

Zeh, A. \& Gerdes, A., 2012. U-Pb and Hf isotope record of detrital zircons from gold-bearing sediments of the Pietersburg Greenstone Belt (South Africa)-Is there a common provenance with the Witwatersrand Basin?. Precambrian Research, 204, 46-56.

Zeh, A., Klemd, R., Buhlmann, S. \& Barton, J. M., 2004. Pro-and retrograde P-T evolution of granulites of the Beit Bridge Complex (Limpopo Belt, South Africa): constraints from quantitative phase diagrams and geotectonic implications. Journal of Metamorphic Geology, 22, 2, 79-95.

Zeh, A., 2001. Inference of a detailed P-T path from P-T pseudosections using metapelitic rocks of variable composition from a single outcrop, Shackleton Range, Antarctica. Journal of Metamorphic Geology, 19, 4, 329-350.

Zitsmann, A., Kiessling, R., Ostwald, J. \& Treder, H-W., 1997. Geological, Geophysical and Geochemical Investigations in the Bui Belt Area in Ghana. Geologisches Jahrbuch, Reihe B, Heft 88. 269p.

\section{Petrological and geochronological constraints on lower crust exhumation during Paleoproterozoic (Eburnean) orogeny, NW Ghana, West African craton.}

Sylvain Block ${ }^{1}$, Jerome Ganne ${ }^{1}$, Lenka Baratoux ${ }^{1}$, Armin $_{\text {Zeh }}^{2}$, Luis A. Parra ${ }^{3}$, Mark Jessell ${ }^{3}$, Laurent Ailleres $^{4}$, Luc Siebenaller ${ }^{1}$ 
${ }^{1}$ Geosciences Environnement Toulouse, Observatoire Midi Pyrénées, 14 ave E. Belin, 31400, Toulouse, France.

${ }^{2}$ Institut für Geowissenschaften, Altenhöfer Allee 1, D-60438 Frankfurt am Main, Germany.

${ }^{3}$ Center for Exploration Targeting, The University of Western Australia, 35 Stirling Highway, Crawley, Perth, Western Australia 6009

${ }^{4}$ Monash University, School of Geosciences, Wellington Road, Clayton, Vic 3800, Australia

\section{SUPPORTING INFORMATION}

\section{APPENDIX S1: COMPLEMENTARY SAMPLES.}

\section{Petrography and mineral chemistry}

Sample BN365 is from an amphibolite unit at the base of a sequence of migmatitic ortho- and paragneisses, in the Bole-Bulenga domain. The kilometric amphibolite sliver is separated from low-grade schists of the Maluwe domain by the Bole-Nangodi shear zone. Petrographic relationships are used to define a succession of three metamorphic assemblages labelled from (A) to (C). The amphibolites contain small volumes of unconnected leucosomes, suggesting limited melting rate and melt loss. The rock is made of a melanocratic Hbl-Pl-Cpx-Ilm-Bt-Qz matrix, and of Grt porphyroblasts (Fig. S1a, b). Grt is unzoned and has compositions of Alm50-54, Grs28-31, Prp15-18 and Sps2-4 (Fig S1h). It contains inclusions of $\mathrm{Hbl}, \mathrm{Pl}$ and Rt. Rt is replaced by Ilm or Tnt (Fig. S1c). Hornblende inclusions in Grt are corroded and have a \#Mg $=0.53-0.55, \mathrm{Ca} / \mathrm{Na}=3.84-4.93$, with $(\mathrm{Na}+\mathrm{Ca})_{\mathrm{B}}=1.84-1.89$ a.p.f.u. and $1385(\mathrm{Na}+\mathrm{K})_{\mathrm{A}}=0.42-0.53$ a.p.f.u., on the basis of 23 oxygens. They are in contact with $\mathrm{Pl}$, which displays variable compositions of An35-46. In contrast, matrix $\mathrm{Hbl}$ has a $\# \mathrm{Mg}=0.57-0.60, \mathrm{Ca} / \mathrm{Na}=4.57-5.81$, $(\mathrm{Na}+\mathrm{Ca})_{\mathrm{B}}=1.88-1.94$ a.p.f.u. and $(\mathrm{Na}+\mathrm{K})_{\mathrm{A}}=0.36-0.39$ a.p.f.u.; and is in contact with chemically homogeneous Pl (An39-45). Clinopyroxene has a diopside composition and a \#Mg = 0.70-0.74. Biotite is a minor retrograde phase representing less than 1 vol\% of the rock, with a $\# \mathrm{Mg}=0.38-0.40$ and $\mathrm{Ti}^{\mathrm{vi}}=$ 

textures between matrix grains (Fig. S1b).

Mineral inclusions in Grt belong to assemblage (A): Grt + $\mathrm{Hbl}+\mathrm{Pl}+\mathrm{Cpx}+\mathrm{Rt}+\mathrm{Qz}+\mathrm{L} \pm \mathrm{Bt}$. Equilibrium contacts between Grt and matrix minerals allow defining the peak metamorphic assemblage (B): Grt $+\mathrm{Hbl}+\mathrm{Pl}+\mathrm{Cpx}+\mathrm{Ilm}+\mathrm{Qz}+\mathrm{L} \pm$ Bt. Garnet porphyroblasts are replaced by leucocratic domains which are dominated by $\mathrm{Pl}$ and contain minor Hbl (Fig. S1a). Grains in the leucocratic rims around garnet are euhedral, with grain boundaries forming $120^{\circ}$ angles, and have compositions similar to matrix grains. These textural relationships suggest garnet resorption and replacement by $\mathrm{Pl}+\mathrm{Hbl}$ at supra-solidus conditions. Replacement of Ilm by titanite illustrates retrogression and the local development of assemblage (C): $\mathrm{Grt}+\mathrm{Hbl}+\mathrm{Pl}+\mathrm{Ttn}+\mathrm{Qz} \pm$ Bt. Further retrogression is documented by the development of Qz-Ep symplectites at the expense of Grt (Fig. S1a).

\section{Sample BN534 (Garnet - kyanite-bearing migmatitic paragneiss)}

Sample BN534 is a metatexite derived from a paragneiss collected in the north-western Bole-Bulenga domain, to the west of the Jirapa SZ. At outcrop scale, it develops foliation-parallel leucosomes connected to cross-cutting leucocratic veins, and displays neosomes comprising aggregates of peritectic Ky and Grt. Petrographic relationships allow to identify three successive metamorphic assemblages labelled from (A) to (C). Grt forms aggregates in Qz-Pl leucocratic domains (Fig. S1d, e). It is unzoned and has compositions of Alm75-76, Prp17-20, Grs4-6, Sps1-3, except for Grt margin which is affected by later re-equilibration and has compositions of Alm77, Prp15-16, Grs6, Sps2 (Fig. S1h). Plagioclase in neosomes and in the matrix have similar compositions of An27-30. Neosomes additionally comprise sheared poikiloblastic Ky which contain Bt, Rt and rare Ms inclusions. These phases belong to a first metamorphic assemblage (A): Grt $+\mathrm{Ky}+\mathrm{Bt}+\mathrm{Ms}+\mathrm{Rt}+\mathrm{Pl}+\mathrm{Qz}+\mathrm{L}$. Rutile and sheared muscovite are absent outside of (partly retrogressed) Ky, which indicates they reacted out to form assemblage (B): Grt + $\mathrm{Ky}+\mathrm{Bt}+\mathrm{Pl}+\mathrm{Qz}+\mathrm{L}$. Matrix biotite has a \#Mg = 0.54-0.59, with $\mathrm{Ti}^{\mathrm{vi}}=0.09-0.13$ a.p.f.u. (11O), similar to grains in neosomes. Quartz crystallised in neosomes contains minor amounts of fibrolite inclusions, suggesting that the rock crossed the solidus under conditions of Sil stability during retrogression (Fig. S1e). Large (up to $0.5 \mathrm{~cm}$ ) flakes of muscovite overgrow neosomes and replace kyanite. They have compositions of Ms77-82, Pg18-23, with $\mathrm{Si}=3.05-3.14$ and $\mathrm{Al}^{\mathrm{vi}}=1.84-1.90$. Staurolites develops at the 
expense of $\mathrm{Ky}$ and has a Mg\# $=14-22$. The latter belong to assemblage $(\mathrm{C}): \mathrm{Grt}+\mathrm{Bt}+\mathrm{St}+\mathrm{Ms}+\mathrm{Pl}+$ Qz.

Sample BN491 (Garnet - kyanite - staurolite- bearing paragneiss)

Sample BN491 originates from the southern extremity of the Bole-Bulenga domain. It is a sub-solidus paragneiss separated by a NNE-striking high-strain zone from diatexites and metatexites represented by sample BN43. It is made of a matrix of oriented Pl-Bt-Ilm-Qz + rare Ms, and contains Grt, St and Ky porphyroblasts (Fig. S1f, g). Grt is subhedral or partially replaced by Bt or St. It displays a zoning pattern typical of growth during prograde metamorphism, with compositions varying from Grt1: Alm70-72, Prp6-8, Grs12-14 Sps9-10; to Grt2: Alm78-81, Prp11-12, Grs6-8, Sps2, from core to rim respectively (Fig. S1f, g). Cation diffusion in Grt2 margins during retrograde evolution is documented by the slight decrease of Prp content to 10 and an increase of Sps content to 3. Grt1 contains Ilm and Chl inclusions (\#Mg = 42-45), which belong to a relict metamorphic assemblage (A). Matrix Bt has \#Mg = 0.45-0.49, with $\mathrm{Ti}^{\mathrm{vi}}=0.12-0.19$ a.p.f.u. (11O), Pl has compositions of An24-26, Ms has a Pg content of $\sim 20$, with $\mathrm{Si}$ = 3.03-3.07 and $\mathrm{Al}^{\mathrm{vi}}=1.86-1.88$. Syn-kinematic Ky porphyroblasts overgrow Grt and are rotated in the metamorphic fabric (Fig. S1f). Ky belongs to assemblage (B): Grt $+\mathrm{Ky}+\mathrm{Bt}+\mathrm{Pl}+\mathrm{Ilm}+\mathrm{Qz} \pm \mathrm{Ms}$, and is partially replaced by post-kinematic muscovite flakes. St forms euhedral porphyroblasts which overgrow the fabric and Grt porphyroblasts (Fig. S1g). They display concentric growth patterns underlined by alternating inclusion-rich and inclusion-free domains. The \#Mg of St decreases from 16-18 to 8-10 from core to rim. Contact between St rim Grt and matrix minerals point to the formation of assemblage (C): Grt $+\mathrm{St}+\mathrm{Bt}+\mathrm{Pl}+\mathrm{Ilm}+\mathrm{Qz}$

\section{Results of P-T pseudosection construction.}

\section{Sample BN365 (migmatitic amphibolite gneiss)}

P-T pseudosection construction (using the sample whole-rock composition) reveals that assemblage (A):

$\mathrm{Grt}+\mathrm{Hbl}+\mathrm{Pl}+\mathrm{Cpx}+\mathrm{Rt}+\mathrm{Qz}+\mathrm{Bt}+\mathrm{L}$ is stable at $>10.0 \mathrm{kbar}, 700-800^{\circ} \mathrm{C}$ (Fig. 2SI a). Calculated Grt compositions indicate $\mathrm{P}>10.5 \mathrm{kbar}, \mathrm{T}=720-750^{\circ} \mathrm{C}$ for the conditions of garnet formation (Fig. S2b). 
Peak metamorphic conditions deduced from Cpx and Pl isopleths belonging to assemblage (B) are found to be $10.0-11.0 \mathrm{kbar}, 730-800^{\circ} \mathrm{C}$ (Fig. S2c). Increasing $\mathrm{Ca} / \mathrm{Na}$ in $\mathrm{Hbl}$ found in the matrix and in leucocratic rims around Grt reveals decompression in the stability field of assemblage (B) (Fig. S2b). This

1450 is consistent with the replacement of Grt $+\mathrm{L}$ by $\mathrm{Hbl}+\mathrm{Pl}$. The retrogression of Rt and Ilm to Tnt and the formation of assemblage (C) requires cooling down at $<9.0 \mathrm{kbar},<700^{\circ} \mathrm{C}$. Sample BN365 followed a clockwise P-T path which crossed the solidus at P>10.0 kbar. Peak metamorphic conditions are reached at the transition between the high-pressure granulite- and amphibolite-facies. They correspond to a moderate apparent geothermal gradient of $15-20^{\circ} \mathrm{C} / \mathrm{km}$.

Sample BN534 (Garnet - kyanite-bearing migmatitic paragneiss)

The pseudosection used to constrain the prograde and peak P-T conditions is identical to that used for sample BN43 (Fig. 7), which is built with the composition of an average paragneiss. Isopleths of retrograde Bt were built using the sample whole-rock composition (Table 2). The formation of assemblage (A): $\mathrm{Grt}+\mathrm{Ky}+\mathrm{Bt}+\mathrm{Ms}+\mathrm{Rt}+\mathrm{Pl}+\mathrm{Qz}+\mathrm{L}$ requires crossing the solidus at $\mathrm{P}>9.5 \mathrm{kbar}$ (Fig. S3a). The evolution from assemblage (A) to assemblage (B) can be accounted for by heating to about $750^{\circ} \mathrm{C}$ and/or decompression, in agreement with measured Grt and Bt compositions (Fig. S3b). Calculated Pl composition only partly match observed composition, possibly due to local equilibria controlling Pl crystallisation from segregated melt in the leucosome. The crystallisation of retrograde sillimanite indicates that the solidus was crossed between 5.0 and 7.0 kbar. Assemblage (C): $\mathrm{Grt}+\mathrm{Bt}+\mathrm{St}$ $+\mathrm{Ms}+\mathrm{Pl}+\mathrm{Qz}$ is calculated to form at conditions of $4-7 \mathrm{kbar},<650^{\circ} \mathrm{C}$. Peak metamorphic conditions recorded by sample BN534 correspond to the amphibolite-granulite facies transition and fit a moderate apparent geothermal gradient of $15-20^{\circ} \mathrm{C} / \mathrm{km}$. The rock followed a clockwise P-T path and was overprinted in the sub-solidus amphibolite facies, along a warmer $20-30^{\circ} \mathrm{C} / \mathrm{km}$ apparent geotherm.

Sample BN491 (Garnet - kyanite - staurolite- bearing paragneiss)

The P-T pseudosection (Fig. S3c, d) is constructed by using the sample whole rock composition (Table 1). Intersecting isopleths corresponding to measured Grt compositions suggests a prograde evolution from 6.5-8.5 kbar, $520-550^{\circ} \mathrm{C}$, to $7.0-9.0 \mathrm{kbar}, 560-590^{\circ} \mathrm{C}$ to form Grt1 and Grt2 respectively (Fig. S3c). At equilibrium, the crystallisation conditions of Grt1 correspond to the stability field of the calculated 
assemblage $\mathrm{Bt}+\mathrm{Chl}+\mathrm{Pg}+\mathrm{Grt}+\mathrm{Pl}+\mathrm{Ilm}+$ Qz. This assemblage may compare to assemblage (A), which is preserved as inclusions in Grt1 and includes Chl $+\mathrm{Ilm}+\mathrm{Qz}$, although no other phases were found to be preserved. Assemblage (B): Grt $+\mathrm{Bt}+\mathrm{Pl}+\mathrm{Ky}+\mathrm{Ms}+\mathrm{Qz}$ is predicted to form at 7.5-9.5 kbar, $610-650^{\circ} \mathrm{C}$. Under these conditions, calculated Pl and Bt compositions show good agreement with measured mineral compositions. The formation of assemblage (C): Grt $+\mathrm{St}+\mathrm{Bt}+\mathrm{Pl}+\mathrm{Ilm}+\mathrm{Qz}$, with St \#Mg varying from 16-10 to 8-10 from core to rim, requires that the rock follows a decompression-cooling path from about $7.0 \mathrm{kbar}, 610^{\circ} \mathrm{C}$ to $4.0 \mathrm{kbar}, 550^{\circ} \mathrm{C}$ (Fig. S3c). The P-T conditions determined from the successive assemblage describe a clockwise P-T path, synchronous peak $\mathrm{P}$ and $\mathrm{T}$ conditions in the amphibolite facies, along a $\sim 20^{\circ} \mathrm{C} / \mathrm{km}$ apparent geotherm.

\section{APPENDIX S2: PSEUDOSECTION CALCULATION}

Pseudosections were constructed using the Perple_X software (Connoly, 2005) updated in 2013 to version 6.6.8, and using the hp04 thermodynamic database of Holland and Powell (1998) updated in 2004. The solution models used for the pseudosection calculations are as follows : Bio(TCC) for biotite (Tajcmanova et al., 2009), Chl(HP) for chlorite (Holland et al., 1998), St(HP) for staurolite (Holland \& Powell, 1998), Ctd(HP) for chloritoïd (Holland \& Powell, 1998), Amph(DPW) for hornblende (Dale et al., 2005), oAmph(DP) for gedrite (Diener et al., 2007), Gt(WPH) for garnet (White et al., 2000), Ilm(WPH) for ilmenite (White et al., 2000), hCrd for cordierite, Mica(CHA1) for titanium bearing white mica (Coggon \& Holland, 2002, Auzanneau et al., 2010), Mica(M) for Ms-Pa-Mrg system (Massonne \& 1495 Willner, 2008), melt(HP) (Holland \& Powell, 1998, White et al., 2001), Pl(h) for plagioclase feldspar (Newton et al., 1981), Kf/San for low/highT potassic feldspar (Waldbaum \& Thompson, 1968), Opx(HP) for orthopyroxene (Holland \& Powell, 1998), Omph(GHP2) for clinopyroxene (Green et al., 2007; Diener \& Powell, 2012), Ep(HP) for epidote (Holland \& Powell, 1998), Act(M) for actinolite (Massonne \& Willner, 2008). Pseudosections were built by using the whole rock composition obtained by XRF analysis for rocks displaying homogeneous mineralogy and mineral modal proportion at sample scale. In the case of heterogeneous samples displaying large porphyroblasts or a compositional layering, whole rock compositions were recalculated based on average mineral compositions and modal proportions established by SEM mapping or image processing techniques. Ferric iron was approximated to 0 based on results of $\mathrm{T}^{-\mathrm{XFe}} \mathrm{e}^{3}$ pseudosections which failed to reproduce observed mineral assemblages. Ca concentration was corrected for apatite and carbonates when they are present in significant amounts. 
Sample BN43 and BN534 are migmatites concerned by melt loss and open-system behaviour. Their metamorphic P-T evolutions were modelled by the complementary use of different pseudosections (White \& Powell, 2002; Johnson et al., 2008). The prograde evolution was investigated by constructing a P-T pseudosection in the MnNCKFMASHT system for an average paragneiss composition, obtained from XRF analyses of 21 subsolidus meta-greywacke samples from the study area (e.g. Johnson \& Brown, 2004) (Table 2). $\mathrm{H}_{2} \mathrm{O}$ content was constrained so that saturation conditions were met on the wet solidus at $10 \mathrm{kbar}$, which corresponds to about 1.15 wt\%. Other pseudosections were built with the whole rock composition of the hand sample, fractionated from garnet cores. This is appropriate to model retrograde subsolidus phase equilibria. T-XFe ${ }^{3}$ pseudosections failed to reproduced observed assemblages for $\mathrm{XFe}^{3}$ $>0.05$, so the proportion of ferric iron was approximated to 0 .

\section{BN47 \& BN491}

P-T pseudosections were built in the MnNCKFMASHT system. Because of the compositional layering inherited from the sedimentary protolith, large staurolite and kyanite porphyroblasts are distributed heterogeneously. The bulk rock chemistries used for modelling were recalculated to take into account local chemical heterogeneities, by evaluating mineral modal proportions in a thin section. The isopleth intersect method was used to constrain the conditions of Grt growth, by comparing measured and calculated Grt compositions. Chemically distinct Grt cores represent small (max. 1vol\%) of the rock. Because of this low proportion, Grt fractionation was found to have insignificant effects.

\section{BN436}

Chemical fractionation due to large Grt porphyroblast growth was integrated to model the metamorphic evolution of sample BN436 (Marmo et al., 2002; Evans, 2004). A first pseudosection was built with the whole rock composition obtained by XRF to model prograde evolution in the MnNCKFMASHT system. A second pseudosection, suitable to interpret peak and post-peak P-T conditions, was constructed in the NCKFMASHT system by fractionating garnet core. Ferric iron content was set to 0 based on results of T$\mathrm{XFe}^{3}$ pseudosections: observed assemblages were successfully modelled for $\mathrm{XFe}^{3}=0$. As a consequence, epidote group minerals are represented by zoisite (Zo) in the P-T pseudosections.

\section{BN365}

Leucosomes in sampe BN365 represent small volumes and are not connected, suggesting that the rock 
composition of the sample and $\mathrm{H}_{2} \mathrm{O}$ was constrained to be saturated on the solidus at $10 \mathrm{kbar}$ (i.e. 1.2 $\mathrm{wt} \%)$.

\section{APPENDIX S3: MULTI-EQUILIBRIA CALCULATIONS}

\section{Quartz-chlorite-phengite- $\mathrm{H}_{2} \mathrm{O}$ thermobarometre}

Multi-equilibria calculations were performed with Matlab $\subset$ on the Chorite-Phengite-Quartz- $\mathrm{H}_{2} \mathrm{O}$ assemblage, following a new procedure detailed in Ganne et al. (2012). Multi-equilibria calculations were performed using the latest thermodynamic model for phengite (Dubacq et al., 2010), which takes into account the T-dependent interlayer water content of dioctahedral mica. Calculations were carried out using the thermodynamic data of five chlorite and six phengite end-members. These end-members are Fe amesite (FeAm: $\left.\mathrm{Si}_{2} \mathrm{Al}_{4}(\mathrm{Fe})_{4} \mathrm{O}_{10}(\mathrm{OH})_{8}\right), \mathrm{Mg}$ amesite (MgAm: $\mathrm{Si}_{2} \mathrm{Al}_{4}(\mathrm{Mg})_{4} \mathrm{O}_{10}(\mathrm{OH})_{8}$ ), clinochlore (Clin: $\mathrm{Si}_{3} \mathrm{Al}_{2} \mathrm{Mg}_{5} \mathrm{O}_{10}(\mathrm{OH})_{8}$ ), daphnite (Daph: $\mathrm{Si}_{3} \mathrm{Al}_{2} \mathrm{Fe}_{5} \mathrm{O}_{10}(\mathrm{OH})_{8}$ ) and sudoite (Sud: $\mathrm{Si}_{3} \mathrm{Al}_{4}(\mathrm{Mg}, \mathrm{Fe})_{2} \mathrm{O}_{10}(\mathrm{OH})_{8}$ for chlorite; and muscovite (Ms: $\mathrm{Si}_{3} \mathrm{Al}_{3} \mathrm{KO}_{10}(\mathrm{OH})_{2}$ ), pyrophyllite ( $\mathrm{Prl}_{\mathrm{S}} \mathrm{Si}_{4} \mathrm{Al}_{2} \mathrm{O}_{10}(\mathrm{OH})_{2}$ ), hydrated pyrophyllite (Prl.H: $\left.\mathrm{Si}_{4} \mathrm{Al}_{2} \mathrm{O}_{10}(\mathrm{OH})_{2} \cdot \mathrm{H}_{2} \mathrm{O}\right)$, Fe celadonite $\left(\mathrm{FeCel}: \mathrm{Si}_{4} \mathrm{Al}(\mathrm{Fe}) \mathrm{KO}_{10}(\mathrm{OH})_{2}\right)$, Mg celadonite (MgCel: $\mathrm{Si}_{4} \mathrm{Al}(\mathrm{Mg}) \mathrm{KO}_{10}(\mathrm{OH})_{2}$ ) and phlogopite (Phl: $\mathrm{Si}_{3} \mathrm{AlMg}_{3} \mathrm{KO}_{10}(\mathrm{OH})_{2}$ for phengite. P-T equilibrium conditions, as well as the $\mathrm{Fe}^{3+}$ content in chlorite and phengite and the water content of phengite were calculated to minimize the sum of the Gibbs free energy $\Sigma \Delta G^{2}$ of the following seven independent reactions:

- (1) 1 Sud + 15 Qtz + 10 FeCel + 2 MgAm > 4 Prl + 10 MgCel + 2 Daph

- (2) $6 \mathrm{MgCel}+7 \mathrm{Qtz}+4 \mathrm{FeAm}+4 \mathrm{H} 2 \mathrm{O}>6 \mathrm{FeCel}+3 \mathrm{Sud}+2 \mathrm{Daph}$

- (3) 5 MgAm + 4 Daph > 5 FeAm + 4 Clin

- (4) $14 \mathrm{Qtz}+5 \mathrm{FeAm}+3 \mathrm{MgAm}+8 \mathrm{H}_{2} \mathrm{O}>4 \mathrm{Daph}+6 \mathrm{Sud}$

- (5) 2 Sud + 4 Qtz + 4 Daph + 4 Ms > 2 Prl.H + 4 MgCel + 5 FeAm

- (6) $1 \mathrm{Prl}+1 \mathrm{H}_{2} \mathrm{O}>1 \mathrm{Prl} . \mathrm{H}$ 
In theory, thermodynamic equilibrium is achieved if $\sqrt{ }\left(\sum \Delta \mathrm{G}^{2} / \mathrm{nr}\right)$ is equal to 0 (nr $=$ number of reactions considered). In practice, however, a deviation from 0 occurs because of analytical uncertainties. Equilibrium is considered to be achieved when $\sqrt{ }\left(\sum \Delta \mathrm{G}^{2} / \mathrm{nr}\right)<2400 \mathrm{~J}$. These values account for the analytical uncertainties and they were estimated after Monte Carlo simulations (Vidal et al., 2006).

\section{Quartz-chlorite- $\mathrm{H}_{2} \mathrm{O}$ and quartz-phengite- $\mathrm{H}_{2} \mathrm{O}$ thermometres}

Multi-equilibria calculations were performed using the Chorite-Quartz- $\mathrm{H}_{2} \mathrm{O}$ assemblage and assuming a water activity equal to unity. It was performed with Matlab@ using a script built by Vincent de Andrade and the thermodynamic data of five chlorite end-members (Vidal et al., 2001) : Fe amesite (FeAm:

$\left.\mathrm{Si}_{2} \mathrm{Al}_{4}(\mathrm{Fe})_{4} \mathrm{O}_{10}(\mathrm{OH})_{8}\right), \quad \mathrm{Mg} \quad$ amesite $\quad\left(\mathrm{MgAm}: \quad \mathrm{Si}_{2} \mathrm{Al}_{4}(\mathrm{Mg})_{4} \mathrm{O}_{10}(\mathrm{OH})_{8}\right)$, clinochlore (Clin: $\mathrm{Si}_{3} \mathrm{Al}_{2} \mathrm{Mg}_{5} \mathrm{O}_{10}(\mathrm{OH})_{8}$ ), daphnite (Daph: $\mathrm{Si}_{3} \mathrm{Al}_{2} \mathrm{Fe}_{5} \mathrm{O}_{10}(\mathrm{OH})_{8}$ ) and sudoite (Sud: $\mathrm{Si}_{3} \mathrm{Al}_{4}(\mathrm{Mg}, \mathrm{Fe})_{2} \mathrm{O}_{10}(\mathrm{OH})_{8}$. With these end members, four independent equilibria can be written.

- (1) 2 Clin + 3 Sud $>4$ MgAm $+7 \mathrm{Qtz}+4 \mathrm{H}_{2} \mathrm{O}$

- (2) 4 Clin + 5 FeAm > 4 Daph + 5 MgAm

- (3) 16 Daph + 15 Sud >20 FeAm + 6 Clin + 35 Qtz + $20 \mathrm{H}_{2} \mathrm{O}$

- (4) 4 Daph + 6 Sud $>5$ FeAm + $3 \mathrm{MgAm}+14 \mathrm{Qtz}+8 \mathrm{H}_{2} \mathrm{O}$

A minimum amount of $\mathrm{Fe}^{3+}$ in chlorite was estimated using the stoichiometric criteria given in Vidal et al. (2005), and $\mathrm{Fe}^{3+}$ content was iteratively modified to minimize $\sum \Delta \mathrm{G}^{2}$ (Vidal et al., 2006). Parra et al. (2002) calibrated a model for the phengite-quartz equilibrium, calculated from activities of chosen end-members, taking into account the non-ideal term of activity coefficients. Dubacq et al. (2010) extended this model to smectite, illite, interlayered smectite-illite and mica by considering the Thydration relationship, pressure and the rock composition, using multi-equilibrium thermobarometry.

The model involves nine end-members: Muscovite (Ms: $\left.\mathrm{Si}_{3} \mathrm{Al}_{3} \mathrm{KO}_{10}(\mathrm{OH})_{2}\right)$, Paragonite (Pg: $\left.\mathrm{Na}\left(\mathrm{Al}_{2}\right)\left(\mathrm{Si}_{3} \mathrm{Al}\right) \mathrm{O}_{10}(\mathrm{OH})_{2}\right)$, Mg-celadonite $\quad\left(\mathrm{MgCel}: \mathrm{Si}_{4} \mathrm{Al}(\mathrm{Mg}) \mathrm{KO}_{10}(\mathrm{OH})_{2}\right)$, Fe-celadonite (Mg-Cel: $\mathrm{Si}_{4} \mathrm{Al}(\mathrm{Fe}) \mathrm{KO}_{10}(\mathrm{OH})_{2}$ ), Phlogopite (Phl: $\left.\mathrm{Si}_{3} \mathrm{AlMg}_{3} \mathrm{KO}_{10}(\mathrm{OH})_{2}\right)$, Annite (Ann: $\mathrm{K}\left(\mathrm{Fe}_{3}\right)\left(\mathrm{Si}_{2} \mathrm{Al}\right) \mathrm{O}_{10}(\mathrm{OH})_{2}$ ), Pyrophyllite (Prl: $\left.\mathrm{Si}_{4} \mathrm{Al}_{2} \mathrm{O}_{10}(\mathrm{OH})_{2}\right)$, hydrated Pyrophyllite $\left(\mathrm{Prl} . \mathrm{H}_{2} \mathrm{O}: \mathrm{Si}_{4} \mathrm{Al}_{2} \mathrm{O}_{10}(\mathrm{OH})_{2} \cdot \mathrm{H}_{2} \mathrm{O}\right.$ ) and Margarite 
(Mrg: $\mathrm{CaAl}_{2}\left(\mathrm{Al}_{2} \mathrm{Si}_{2}\right) \mathrm{O}_{10}(\mathrm{OH})_{2}$ ). Three independent equilibria - and their hydrated derivatives - can be written for the Phg-Qtz-water assemblage.

- (5) $3 \mathrm{MgCel} . \mathrm{mH}_{2} \mathrm{O}+2$ Prl. $(\mathrm{m}+1) \mathrm{H}_{2} \mathrm{O}>2 \mathrm{Musc} \mathrm{mH}_{2} \mathrm{O}+\mathrm{Phl} . \mathrm{mH}_{2} \mathrm{O}+11 \mathrm{Qtz}+(2 \mathrm{~m}+4) \mathrm{H}_{2} \mathrm{O}$

- (6) 3 FeCel.mH $\mathrm{H}_{2} \mathrm{O}+2$ Prl. $(\mathrm{m}+1) \mathrm{H}_{2} \mathrm{O}>2 \mathrm{Musc} \mathrm{mH}_{2} \mathrm{O}+\mathrm{Ann} \cdot \mathrm{mH}_{2} \mathrm{O}+11 \mathrm{Qz}+(2 \mathrm{~m}+4) \mathrm{H}_{2} \mathrm{O}$

- (7) $\mathrm{Prl} .(\mathrm{m}+1) \mathrm{H}_{2} \mathrm{Onw}>$ Prl.(m’+1) $\mathrm{H} 2 \mathrm{Onw}+\left(\mathrm{m}-\mathrm{m}^{\prime}\right) \mathrm{H}_{2} \mathrm{O}$

where $(m+1)$ and $\left(m^{\prime}+1\right)$ are the maximum and minimum amount of water, with $m$ and $m^{\prime}$ varying from 0 to 6 and 0 to 3 according to the water layers content (noted nw). Fe3+ is not taken into account by the model. The hydration state is modified iteratively to minimize $\sum \Delta \mathrm{G}^{2}$. Calculations are carried out with Matlab@ software using a script build by Benoit Dubacq.

The Quartz-Chlorite-Phengite- $\mathrm{H}_{2} \mathrm{O}$ thermobarometre provided satisfactory results for sample BN185. $646 \times 441 \mathrm{Ph} / \mathrm{Chl}$ microprobe point analyses were first filtered on the basis of the compositional criteria (Vidal \& Parra, 2000). Calculations of P-T equilibrium conditions eventually involved $198 \times 162$ $\mathrm{Ph} / \mathrm{Chl}$ analyses. Calculations for samples BN246, BN35 and BN44 failed to fulfill strict equilibrium criteria by using the Quartz-Chlorite-Phengite- $\mathrm{H}_{2} \mathrm{O}$ thermobarometre. P-T conditions were investigated independently by coupling the Quartz-Chlorite- $\mathrm{H}_{2} \mathrm{O}$ and Quartz-Phengite- $\mathrm{H}_{2} \mathrm{O}$ thermometres. Multiequilibria calculations involved respectively 139, 4 and 19 chlorite analyses, and 3, 26 and 47 phengite analyses for samples BN35, BN44, and BN246.

\section{APPENDIX S4: U-PB DATING}

\section{SHRIMP II analytical techniques}

Selected monazite crystals as small as $10 \mu \mathrm{m}$ from samples BN43 and BN47 were dated using Sensitivity High Resolution Ion Microprobe (SHRIMP II). The selected crystals were cut it into 3 mm discs out from polished thin sections, and were later casted into an a 25mm epoxy disc and prepared for SHRIMP analysis as described by Rasmussen et al. (2010). Analytical conditions and procedures are described in Foster et al. (2000) and Rasmussen et al. (2001). Internal calibration was done using the standards GM3, IND and VK 1 (Rasmussen et al. 2002; Kennedy \& Kinny, 2004; Schmitz et al., 2009; Fletcher et al., 2010; Ruschel et al., 2012; Wingate \& Kirkland, 2013). 


\section{LA-ICP-MS analytical techniques}

1615 Uranium, thorium and lead isotopes were analyzed using a ThermoScientific Element 2 sector field ICPMS coupled to a Resolution M-50 (Resonetics) 193 nm ArF excimer laser (ComPexPro 102F, Coherent) system, using the procedures described by Gerdes \& Zeh (2006, 2009) with modifications explained in Zeh \& Gerdes (2012). During this study the unknown monazite grains were analysed together with the standard zircon GJ-1 (Jackson et al., 2004), and with the standard monazites Moacir (Gasquet et al., 2010) and Manangotry (Horstwood et al., 2000). Most monazite grains (unknowns and standards) were ablated with a laser spot-size of $19 \mu \mathrm{m}$ diameter, but for high-U monazite, a smaller spot size of $12 \mu \mathrm{m}$ have been employed. Ablation was done with a repetition rate of $4 \mathrm{~Hz}$, and ca. $2 \mathrm{~J} \mathrm{~cm}^{-2}$ laser energy. Particle transport was performed in a $0.63 \mathrm{l} \mathrm{min}^{-1} \mathrm{He}$ stream, which was mixed directly after the ablation cell with $0.02 \mathrm{l} \mathrm{min}^{-1} \mathrm{~N}_{2}$ and $0.83 \mathrm{l} \mathrm{min}^{-1}$ Ar prior to introduction into the Ar plasma of the SF-ICP-MS. Signal was tuned for maximum sensitivity for $\mathrm{Pb}$ and $\mathrm{U}$ while keeping oxide production, monitored as ${ }^{254} \mathrm{UO} /{ }^{238} \mathrm{U}$, below $0.2 \%$. The sensitivity achieved was in the range of ca. $12900 \mathrm{cps} / \mu \mathrm{g} \mathrm{g}{ }^{-1}$ for ${ }^{238} \mathrm{U}$ with a $33 \mu \mathrm{m}$ spot size, at $5.0 \mathrm{~Hz}$ and $5 \mathrm{~J} \mathrm{~cm}^{-2}$ laser energy (obtained on the standard zircon GJ1). Sample surfaces were cleaned directly before each analysis by three pulses pre-ablation. Raw data were corrected offline for background signal, common $\mathrm{Pb}$, laser induced elemental fractionation, instrumental mass discrimination, and time-dependent elemental fractionation of $\mathrm{Pb} / \mathrm{U}$ using an in-house MS Excel@ spreadsheet program (Gerdes \& Zeh, 2006, 2009). The common-Pb correction was carried out when the common- $\mathrm{Pb}$ uncorrected ${ }^{207} \mathrm{~Pb} /{ }^{206} \mathrm{~Pb}$ was significantly higher than the corrected ${ }^{207} \mathrm{~Pb} /{ }^{206} \mathrm{~Pb}$. For most analyses the common $\mathrm{Pb}$ level (quoted here as ${ }^{206} \mathrm{~Pb}$ common of total ${ }^{206} \mathrm{~Pb}$ ) was below $0.2 \%$ (see Table 5). Common- $\mathrm{Pb}$ correction was carried out by using the ${ }^{202,204} \mathrm{Hg}$ interference- and background-corrected

${ }^{204} \mathrm{~Pb}$ signal, and a model $\mathrm{Pb}$ composition (Stacey \& Kramers, 1975). The interference of ${ }^{204} \mathrm{Hg}$ (ca. 250 cps; counts per second, during our sessions) on mass 204 was estimated using a ${ }^{204} \mathrm{Hg} /{ }^{202} \mathrm{Hg}$ ratio of 0.2299 and the measured ${ }^{202} \mathrm{Hg}$. Laser induced elemental fractionation and instrumental mass discrimination were corrected by normalization to the reference zircon GJ-1 (primary standard). Potential matrix effects were controlled by multiple measurements of the standard monazites Moacir and 1640 Managotry (secondary standards). Prior to the normalization, the drift in inter-elemental fractionation $(\mathrm{Pb} / \mathrm{U})$ during 21s of sample ablation was corrected for the individual analysis. The correction was done by applying a linear regression through all measured ratios, excluding the outliers $( \pm 2 \sigma$ standard deviation; 2 SD), and using the intercept with the y-axis as the initial ratio (=intercept method). The total offset of the measured drift-corrected ${ }^{206} \mathrm{~Pb} /{ }^{238} \mathrm{U}$ ratio from the “true” ID-TIMS value $(0.0982 \pm 0.0004$; ID- 
1645 TIMS GUF-value) of the analyzed GJ-1 grain was ca.11\%. Reported uncertainties $(2 \sigma)$ of the ${ }^{206} \mathrm{~Pb} /{ }^{238} \mathrm{U}$ ratio were propagated by quadratic addition of the external reproducibility (2 SD \%) obtained from standard GJ-1 ( $\mathrm{n}=11 ; 2$ SD 1.23\%) during the analytical session, and the within-run precision of each analysis (2 SE \%; standard error). Reproducibility of the ${ }^{207} \mathrm{~Pb} /{ }^{206} \mathrm{~Pb}$ ratio depends strongly on counting statistic (see Gerdes \& Zeh, 2009), as well as on the common-Pb content. To account for both, the uncertainty on ${ }^{207} \mathrm{~Pb} /{ }^{206} \mathrm{~Pb}$ signal were propagated by quadratic addition of the outlier corrected ${ }^{207} \mathrm{~Pb} /{ }^{206} \mathrm{~Pb}$ within-run precision (2 SE\%), a ${ }^{207} \mathrm{~Pb}$ signal dependent factor, and an factor which takes the amount of common-Pb, and the uncertainties of model Pb composition into account (Gerdes \& Zeh, 2009). The ${ }^{207} \mathrm{~Pb} /{ }^{235} \mathrm{U}$ ratio is derived from the normalized and error propagated ${ }^{207} \mathrm{~Pb} /{ }^{206} \mathrm{~Pb}$ and ${ }^{206} \mathrm{~Pb} /{ }^{238} \mathrm{U}$ ratios, assuming a ${ }^{238} \mathrm{U} / 235 \mathrm{U}$ natural abundance ratio of 137.88 and the uncertainties of both ratios. The standard 1655 zircon GJ1 ( $\mathrm{n}=11)$ measured during this study yield a Concordia ages of $604.1 \pm 2.7$ Ma ( $\mathrm{n}=11$, MSWD $=0.55$, Probability of fit $=0.95$ ). Multiple measurements of the standard monazite Moacir yield a Concordia age of $500.7 \pm 2.5(n=11$, MSWD=1.4, Probability of fit $=0.12)$ and of the standard monazite Manangotry a Concordia age of $552.3 \pm 2.8(\mathrm{n}=11$, MSWD=1.18, Probability of fit $=0.26)$ which are within error of published data (Horstwood et al., 2000; Gasquet et al., 2010). The data were plotted using the software ISOPLOT (Ludwig, 2001). 
1675 Fig. 1. Simplified geological map of the Leo-Man rise (modified after the BRGM SIGAfrique map, Milési et al., 2004). Light green areas are made of intermediate to acidic volcano-sedimentary or volcanoclastic rocks, and the dark green areas represent mafic volcanic rocks.

Fig. 2. Litho-structural map of the study area. BGD: Bawku granitoid domain. JB: Julie Belt; WLGD: Wa - Lawra granitoid domain. GD = granitoid domain, SZ = shear zone. Fault kinematics are indicated when they are unambiguous.

Fig. 3. Photomicrographs of metapelite samples BN43 (a-e) and BN47 (f). (a) Garnet (Grt2) grains form atoll-shaped aggregates around a leucocratic Pl-Qz rich domain containing a prismatic sillimanite porphyroblast. Biotite in the leucosome is resorbed. Fibrolite (Sil) and staurolite develop on the margins of the leucosome. Fibrolite needles also form inclusions in garnet. (b) Garnet porphyroblast showing an inclusion rim of fibrolite needles at the contact between garnet 1 and 2. The profile refers to Fig. 4f. Kyanite and prismatic sillimanite are set in a Qz-rich leucosome. Fibrolite and biotite flakes are found at the contact between leucosome and matrix. (c) Kyanite containing oriented inclusions of Ms (and Pg) overgrown by prismatic sillimanite in a neosome. (d) Elongated crystals of prismatic sillimanite are closely intergrown with granular quartz, as well as with corroded grains of plagioclase and biotite. (e) Biotite-ilmenite selvedge around a neosome which contains fibrolite-muscovite intergrowths. (f) Subhedral Grt displays inclusion-poor cores (white dashed contour) and is included in St. Poikiloblastic St1 contains oriented Qz-ilm inclusions. Grt and St1 are overgrown by post-kinematic euhedral St2. St2 overprints the metamorphic banding defined by oriented Bt, Pl, Ky Ilm and Qz.

Fig. 4. Photomicrographs of samples BN436 (a-d) and BN185 (e). (a) Pluri-mineral inclusion in Grt porphyroblast core, including Chl, Ep, Rt and Qz. (b) Pluri-mineral inclusion in Grt core including Qz, Pg, Pl, St, Ilm, Tur and Chl with a radial growth pattern. (c) Ky, Ged and Rt in contact in the matrix belong to the peak metamorphic assemblage. (d) Retrograde phases in the matrix include St, fibrous Chl and intergrown Chl + Pg. They develop in replacement of the assemblage shown in d), which includes plagioclase feldspar, gedrite and kyanite. Note the abundance of rutile included in these phases and in the Chl + Pg pseudomorphs. (e) Chlorite-muscovite-quartz alternation defines foliation and develops in pressure shadow zones of plagioclase porphyroclasts in volcano-sedimentary schist BN185. (f) Chemical composition variations along radial profiles across garnet porphyroblasts of the three samples from the high-grade Bole-Bulenga and Abulembire domains presented in the text. The location of the profile for 
Fig. 5. Modal proportion of metamorphic porphyroblasts deduced from thin section image analysis for samples BN43 (a, c) and BN47 (b, d).

Fig. 6. Ternary diagrams showing the end-member proportions of chlorite and white mica from sample BN185 used for multi-equilibria calculations. Values are in a.p.f.u. Colours illustrate mineral groups defined by compositional criterias.

Fig. 7. P-T pseudosections presenting phase equilibria for sample BN43. (a-d) Stable assemblages calculated from an averaged paragneiss composition (Table 2, Appendix S1). (b) Calculated Grt Prp and Grs content (black dashed lines, numbers in boxes and dotted lines, numbers in circles, respectively) and Grt mode. The shaded domain represents the P-T field of Grt1 formation. The thick dashed line represents the stability field and compositional range of assemblage G modelled from the composition of BN43. (c) Calculated Pl An content (black dashed lines, numbers in boxes), and modal proportions of aluminosilicates. (d) Calculated melt fraction (dashed lines, numbers in circles). The shaded domain shows the stability field of retrograde staurolite. This domain, along with the $\mathrm{AMg}$ of retrograde $\mathrm{Bt}$ (dashed lines, numbers in boxes), is determined from pseudosection calculation using whole rock composition of sample BN43, which is suitable to study metamorphic phase relationships during the retrograde evolution of the sample. Capital letters A to E refer to assemblages identified in section 3. R1 and R2 refer to reactions identified in section 3. A possible P-T path consistent with observed petrological relationships is shown.

Fig. 8. MnNCKFMASHT P-T pseudosections illustrating phase equilbria for metagreywacke sample BN47. (a) Calculated stable assemblages. (b) Calculated Grt Prp and Grs content (black dashed lines, numbers in boxes and dotted lines, numbers in circles, respectively) and Grt mode. The shaded domain represents the P-T fields of Grt1 and Grt2formation. (c) Calculated biotite and staurolite \#Mg (dotted line, number in circles, and dashed line, number in boxes respectively) and staurolite modal proportion. (d) A$\mathrm{D}$ and R1 refer to metamorphic assemblages and reactions identified in section 3. A P-T path consistent with petrological relationships is drawn.

Fig. 9. P-T pseudosections displaying phase equilibria for sample BN436. (a-b): pseudosections showing metamorphic phase relationships suitable to determine the prograde metamorphic evolution of the sample. (a) Calculated stable assemblages. (b) Light shaded domain represents the assemblages where ilmenite is stable. Dark shaded boxes with dashed and full outlines respectively show the equilibrium conditions of St1 and Grt core formation.. (c-d) pseudosections presenting phase relationships after garnet fractionation 
(Table 2, Appendix S1). (c) Calculated stabl assemblages. (d) Light shaded domain represents the multivariant domain corresponding to observed peak metamorphism assemblage. Dark shaded box shows formation conditions of St2. Invariant point $\mathbf{i}$ represents a minimal P constraint for the coexistence of garnet with zoisite and rutile. Isopleths of Grt Prp and Grs content, and of Pl An content are shown, along with a possible P-T path consistent with observations.

Fig. 10. P-T diagram presenting the chemical composition of chlorite vs P-T equilibrium conditions. The black arrow shows a P-T path consistent with multi-equilibria calculations. Each point on the P-T diagram represent equilibrium conditions for one chlorite analysis, equilibrated with one white mica analysis by the multi-equilibria method described in Appendix S2.

1745 Fig. 11. (a-e): Results of U-Pb dating of monazite of samples BN43, BN47 and BN436, presented in Concordia diagrams. Errors include decay constant uncertainties. (a, c, e): Results of U-Pb dating by LAICP-(SF)-MS. (b, d): Results of U-Pb dating by SHRIMP. Shaded ellipses represent concordant analyses used for Concordia age calculation. Yellow ellipses in (a) show results of spot analyses from an inherited grain yielding an older age. (f-g): Back scattered electron images. Arrows in (f) point to monazite 1750 inclusions in a garnet porpyroblast of sample in BN436. (h) Monazite grain included in kyanite in sample BN47. (i) Dashed line marks the boundary between the neosome (bottom) and paleosome (top) in sample BN43. (j) Monazite grains indicated by arrows, in leucosome and selvedge biotite of sample BN43.

Fig. 12. Metamorphic map of northwestern Ghana showing the position of studied samples, corresponding schematic P-T diagrams, and the spatial distribution of metamorphic facies. Blue boxes a and $\mathrm{b}$ refer to detailed maps in Fig. 14. Colored fields in P-T diagrams are deduced from P-T pseudosections. They represent equilibrium conditions for the formation of specific minerals or assemblages which serve as constraints to P-T paths.

Fig. 13. Synthesis of P-T conditions and P-T paths deduced from the metamorphic study of rocks from high-grade and low-grade units. Individual samples are labelled and are identified from Fig. 12.

Fig. 14. (a, b) Structural-metamorphic maps of the northern and southern extremities of the Bole-Bulenga terrane, delimited by the Bulenga and Bole shear zones respectively. (see Fig. 12 for location). Small spacing between S1 foliation trajectory lines illusrtrates high strain intensity. (c) Outcrop from the extensional Bulenga shear zone displaying shallow dipping high-strain fabric and down-dip mineral 
stretching lineation, plunging towards decreasing metamorphic grade. (d) P-T diagram illustrating various P-T paths obtained from rocks of the Bole-Bulenga terrane. Segments attributed to evolution during extensional deformation D2 are highlighted.

Fig. S1. Photomicrographs of samples BN365 (a-c), BN534 (d-e) and BN491(f-g). (a) Grt porphyroblasts are partially resorbed and rimmed by euhedral $\mathrm{Hbl}$ and $\mathrm{Pl}$ grains. The rock matrix is dominated by $\mathrm{Hbl}$ and additionally contains $\mathrm{Hbl}+\mathrm{Pl}+\mathrm{Ilm}+\mathrm{Cpx}$. (b) Hbl and Cpx in contact in the matrix. Grain boundaries occasionally contain Qz-Pl 'beads' which may represent melt relics. (c) Rt relics in Grt core replaced by intergrown Ilm-Tnt. (d) Millimetric Rt grains in contact with Grt-Ky aggregates in Pz-Pl neosomes bounded by oriented Bt selvedges. (e) Rare Sil fibres and large Ms flakes form late-stage phases in leucosomes. (f) Ky porphyroblast overgrows Grt and is rotated relative to oriented matrix Bt-PlMs-Qz. Retrograde Ms develops at the expense of Ky. (g) Euhedral St overgrows the fabric. Qz-Ilm grains form concentric inclusion trails illustrating porphyroblast growth. (h) Chemical composition profiles across Grt porphyroblasts of samples BN365, BN534 and BN491.

Fig. S2. MnNCKFMASHT P-T pseudosections illustrating phase equilbria for amphibolite sample BN365. (a) Calculated stable assemblages. (b) Calculated Grt Prp and Grs content, and Ca/Na ratio in Hbl (black dotted lines, numbers in boxes, dashed lines, numbers in circles, and bold dashed lines, numbers in diamonds respectively) and Grt mode. The shaded domain is defined by the intersection of calculated Grt isopleths fitting measured compositions. (c) Calculated Pl An composition and Cpx \#Mg (bold dashed and dotted line, number in circles, and dashed line, number in boxes respectively). The shaded domain represents the intersection of calculated $\mathrm{Pl}$ and $\mathrm{Cpx}$ isopleths matching measured compositions. (d) A-C refer to metamorphic assemblages identified in Appendix S1. A P-T path consistent with observations is drawn.

Fig. S3. (a, b) MnNCKFMASHT P-T grid calculated using the average paragneiss composition (similar to Fig. 7) used to determine the metamorphic evolution of migmatite sample BN534. (a) Calculated Grt Prp and Grs content (black dashed lines, numbers in boxes and dotted lines, numbers in circles, respectively). The shaded area is defined by the intersection of calculated Grt isopleths matching measured compositions. (b) Calculated Pl An content (similar to Fig. 7, dashed lines, numbers in boxes), and $\mathrm{Bt} \# \mathrm{Mg}$ (using the sample whole rock composition, dotted lines, numbers in circles). A-C refer to assemblages identified in Appendix S1, and a possible P-T path is shown. (c, d) MnNCKFMASHT 
pseudosections illustrating phase equilbria for paragneiss sample BN491. (c) Calculated stable assemblage and Pl isopleths matching measured Pl compositions. (d) Calculated garnet Prp (numbers in boxes) and Grs content (numbers in circles), along with the \#Mg of Bt (numbers in diamonds) and St (numbers in ellipses). A-C indicate assemblages identified in Appendix S1, and a possible P-T path is shown.

\section{TABLE CAPTIONS}

Table 1. Description and location of samples investigated in this study.

Table 2. Chemical compositions (oxide wt\%) of samples used for P-T pseudosection construction.

Table 3. Representative chemical compositions of minerals forming metamorphic assemblages used to constrain P-T conditions and P-T paths from pseudosections. Exc. = excess

1810 Table 4. Results of Quartz-Chlorite-Phengite- $\mathrm{H}_{2} \mathrm{O}$ multi-equilibria calculations. Chemical compositions of representative white mica and chlorite mineral pairs which met equilibrium conditions are presented. Equilibrium is considered to be achieved for $\mathrm{dG}<2400 \mathrm{~J}$ (SI B).

Table 5. U-Pb isotopic data obtained by LA-ICP(SF)-MS analyses at Goethe University Frankfurt, Germany, and by SHRIMP at JLC in Perth, Australia.

1815 Table S1. Representative chemical compositions of minerals forming metamorphic assemblages used to constrain P-T conditions and P-T paths from pseudosections. Exc. = excess

Table S2. Chemical compositions and structural formulae of chlorite and white mica used for multi-equilibria calculations. 
Fig. 1

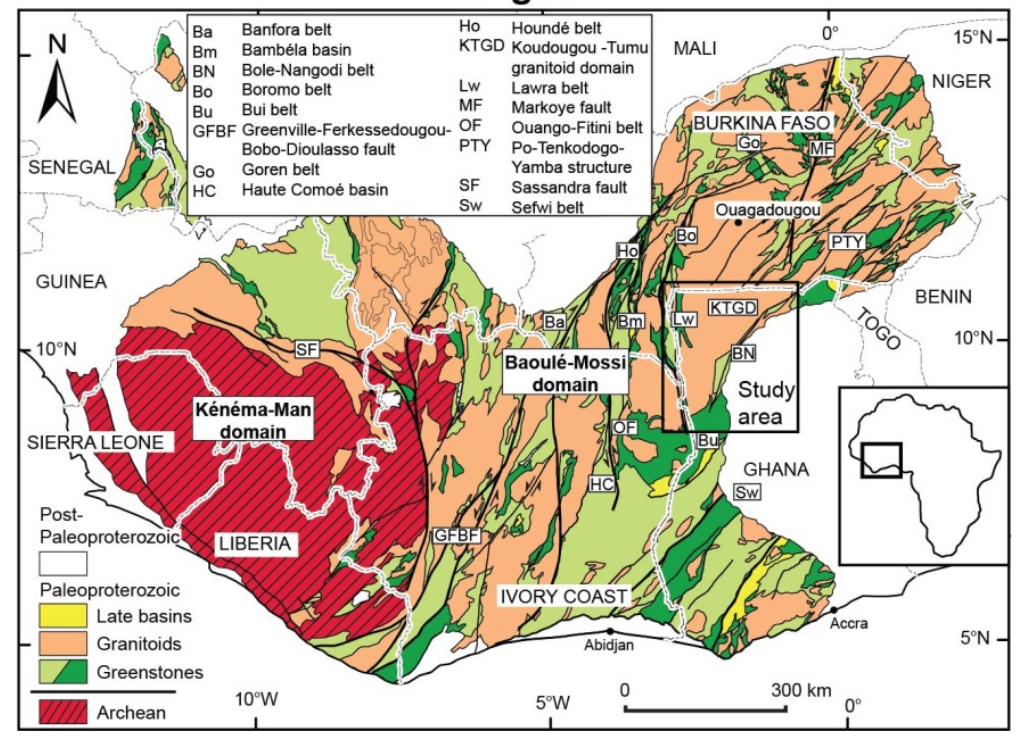

Fig. 2

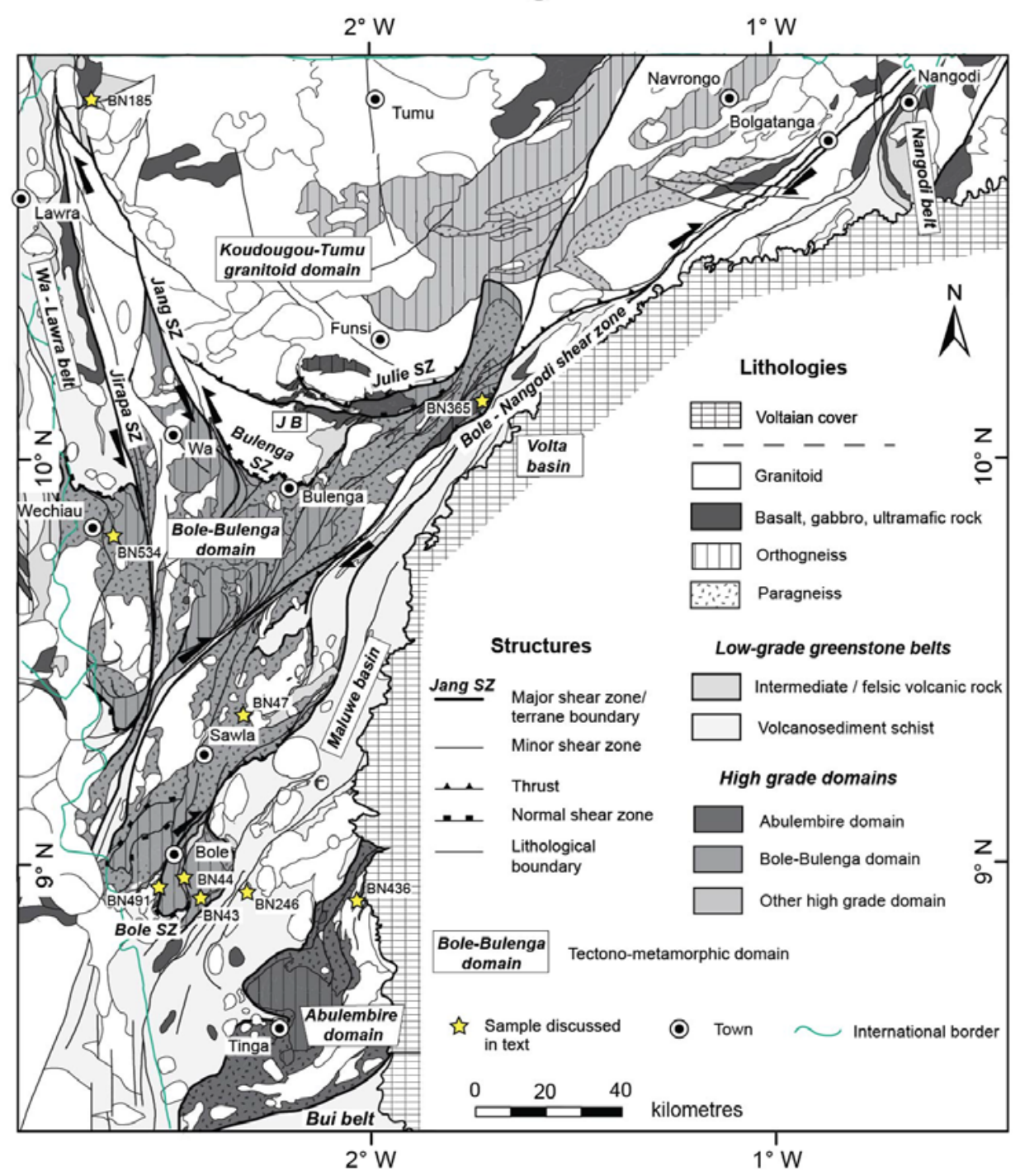


Fig. 3
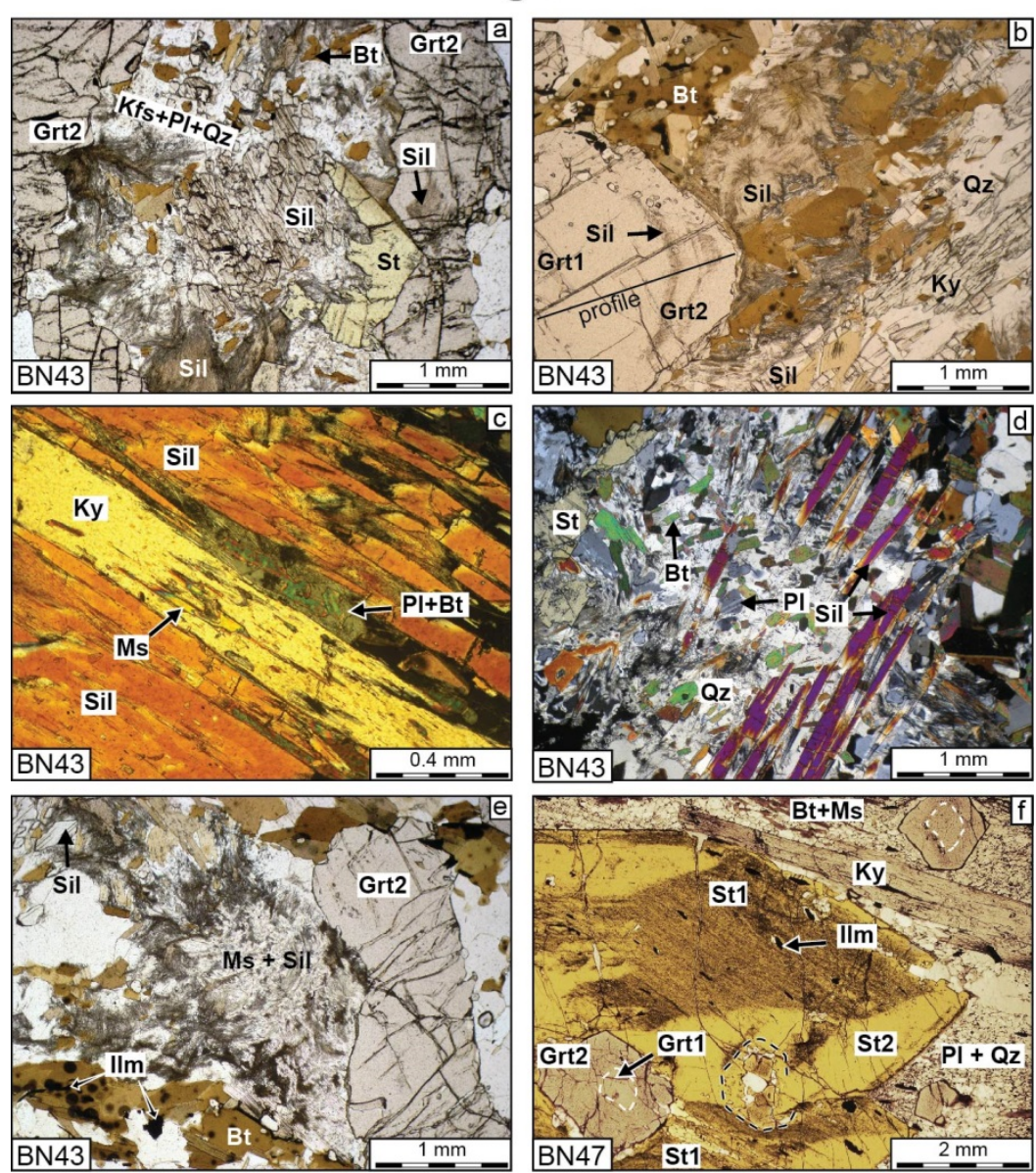

Fig. 4
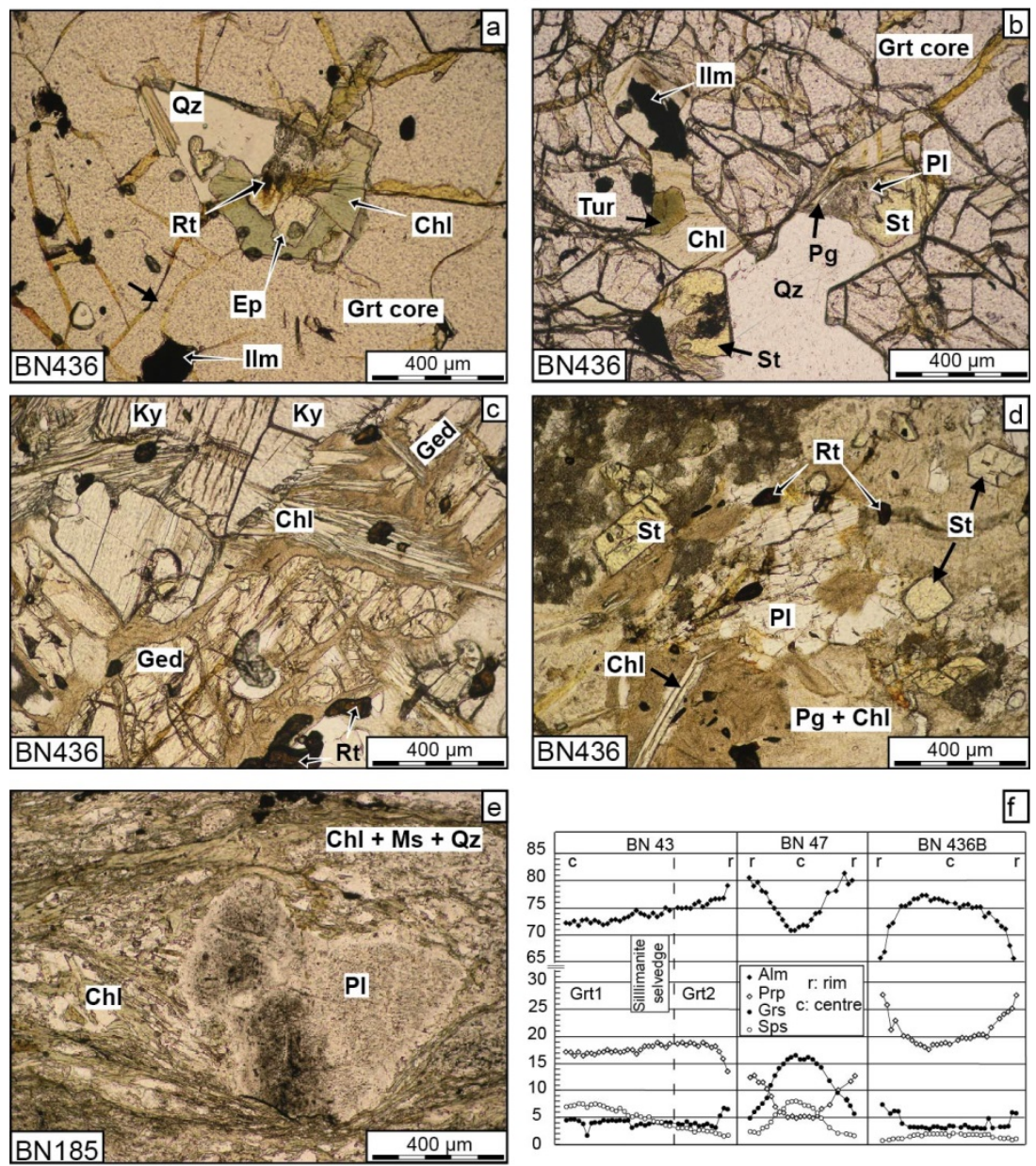
Fig. 5
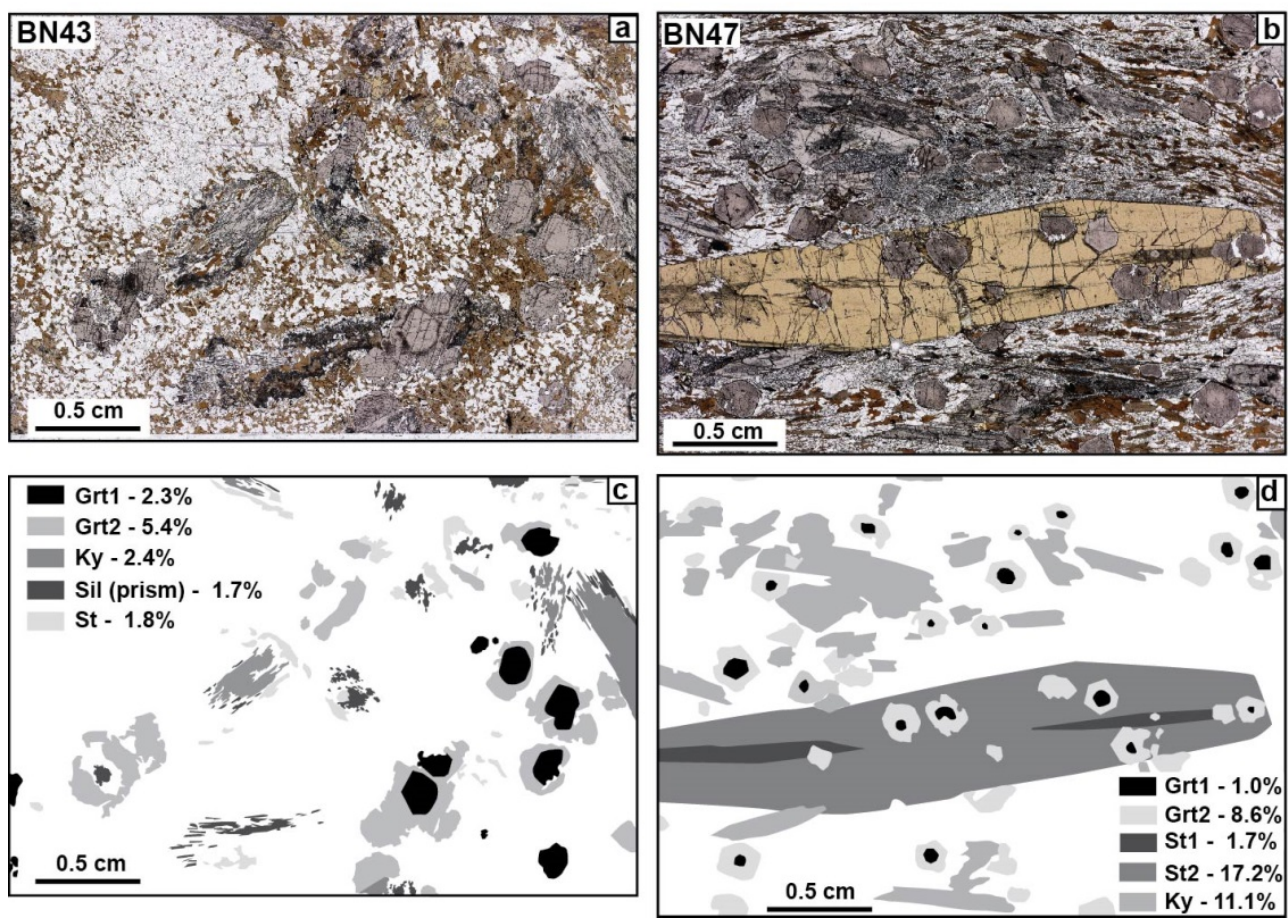

Fig. 6

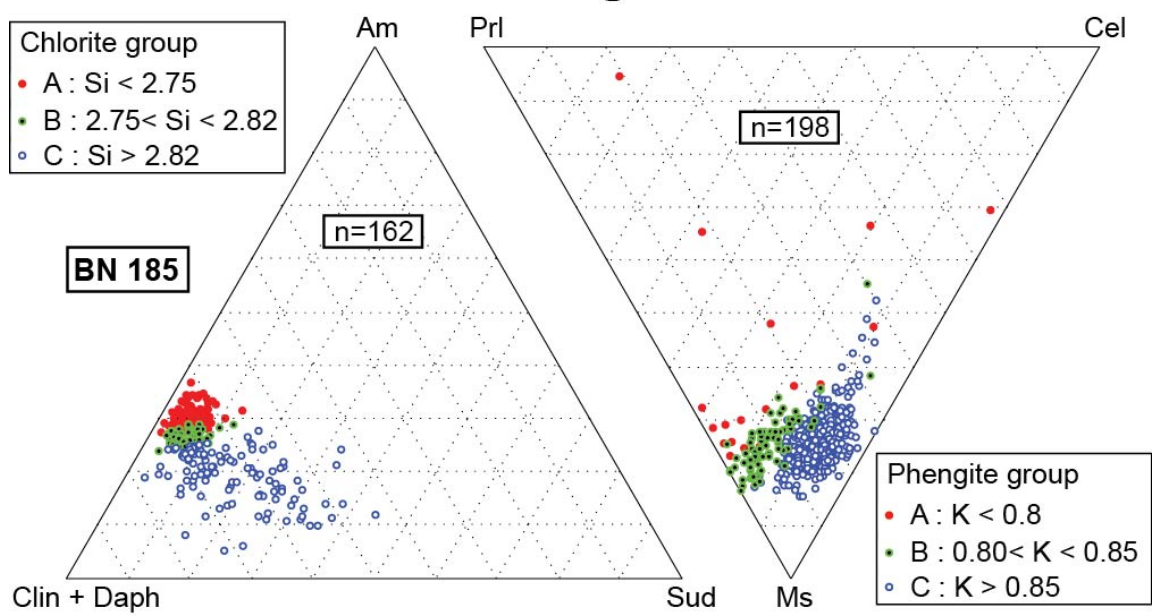


Fig. 7
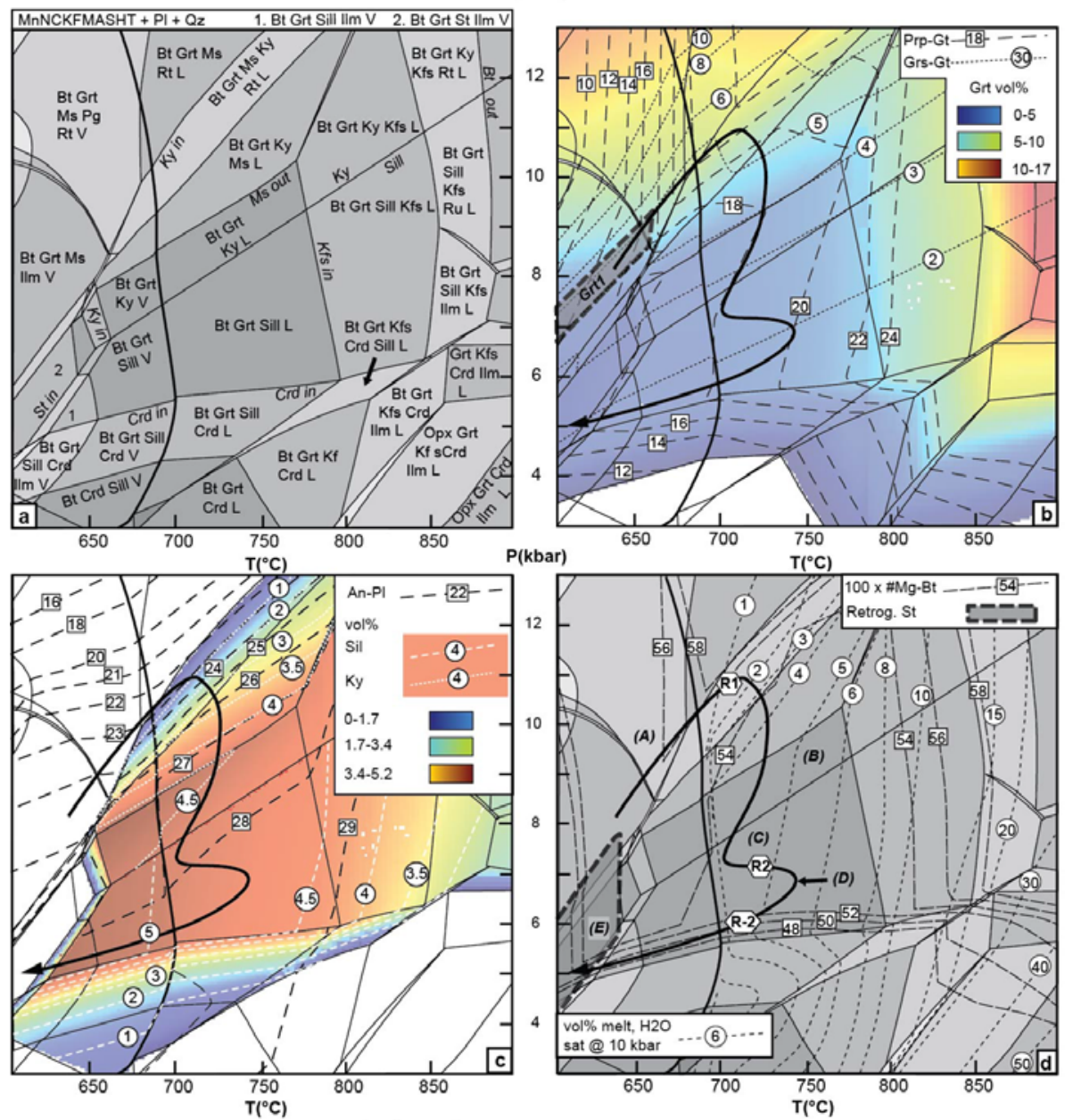

Fig. 8

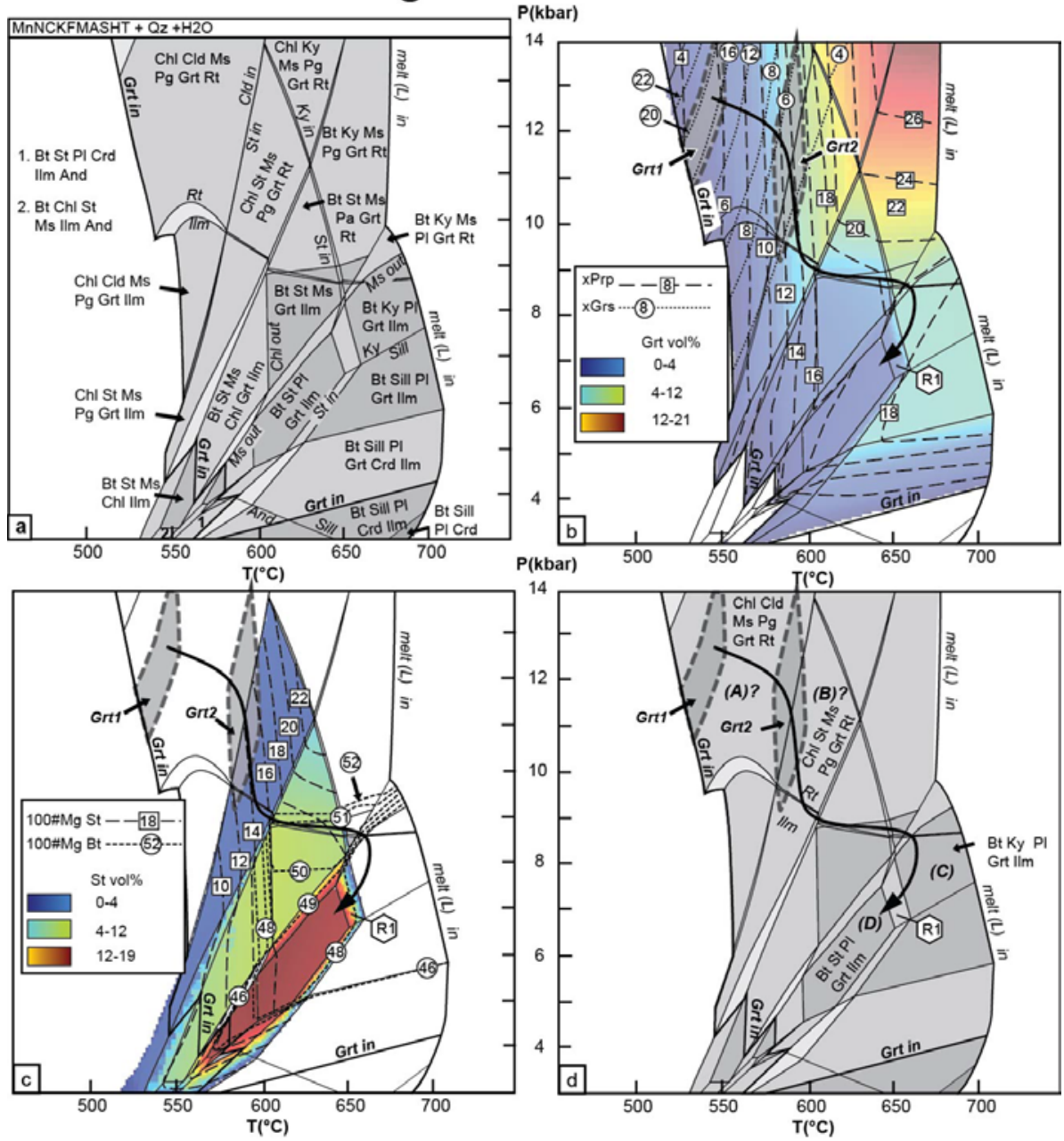


Fig. 9
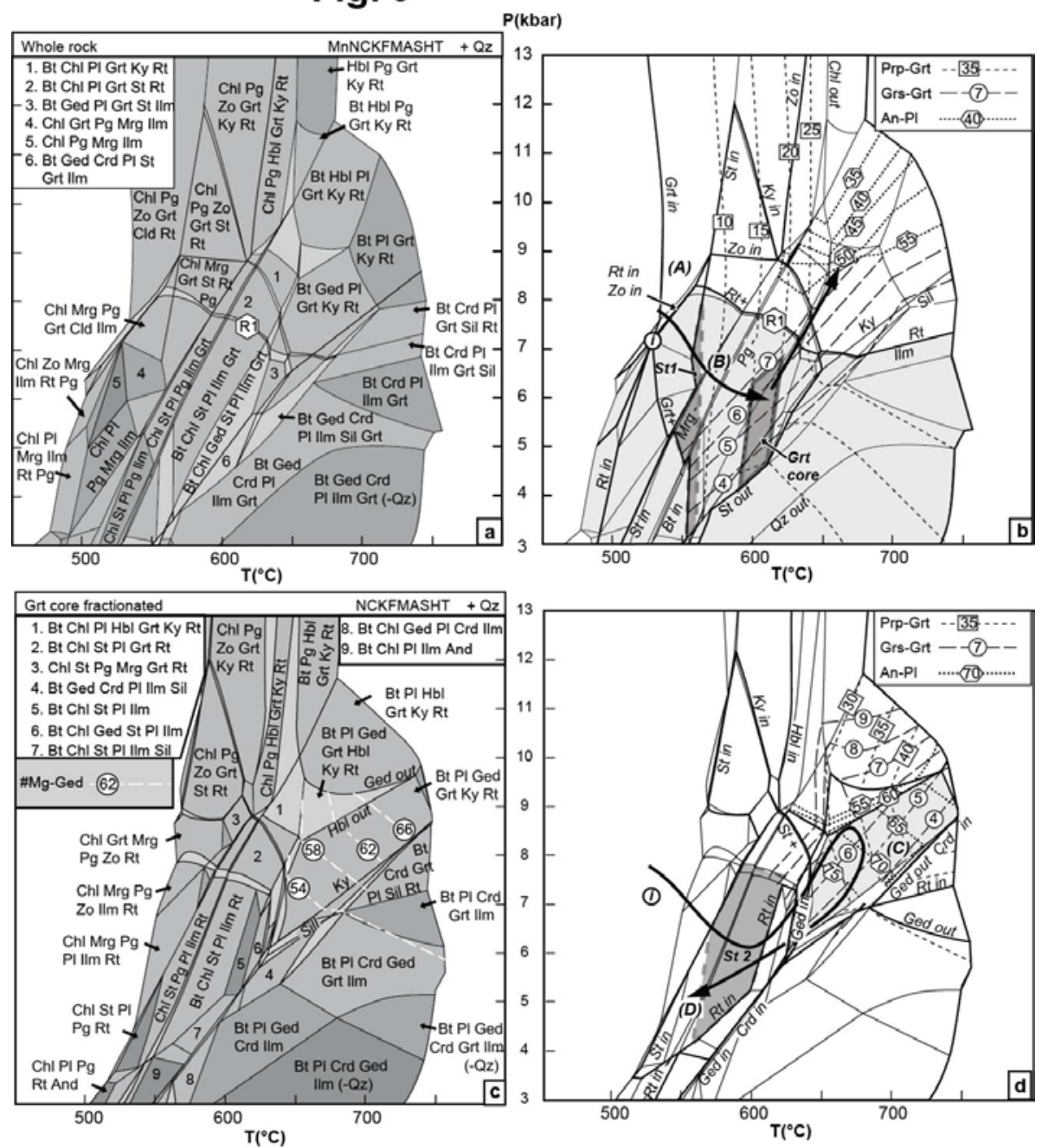

Fig. 10

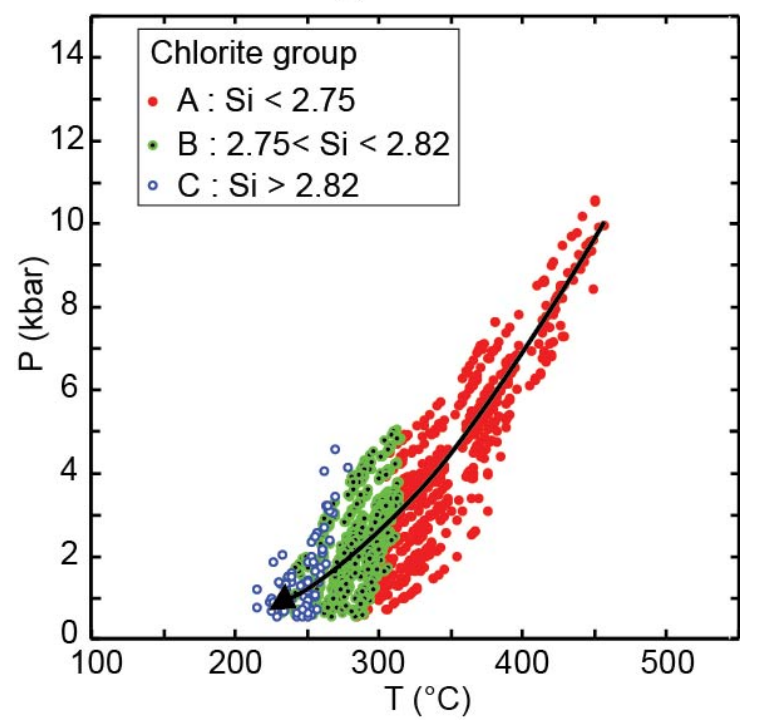


Fig. 11
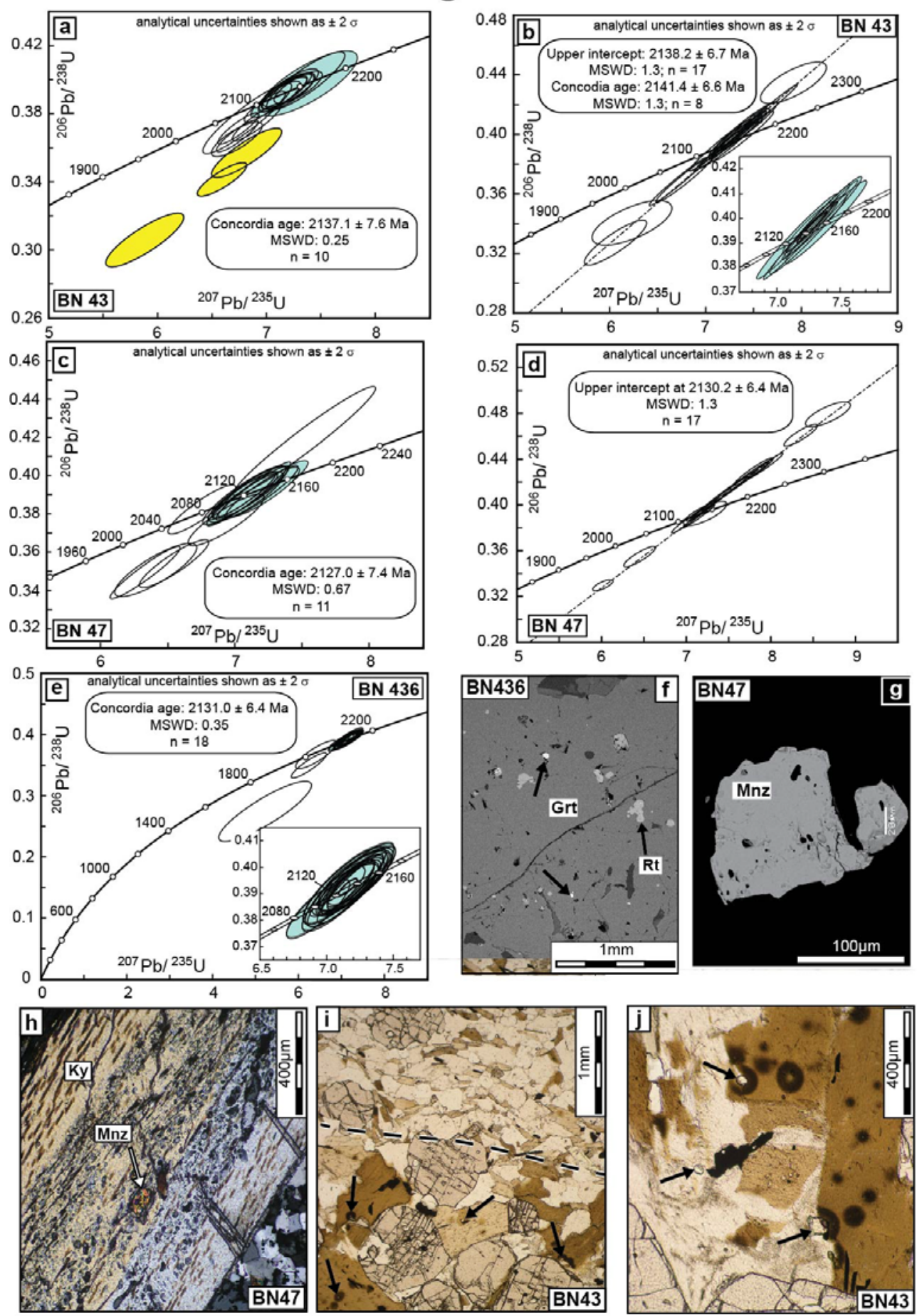
Fig. 12

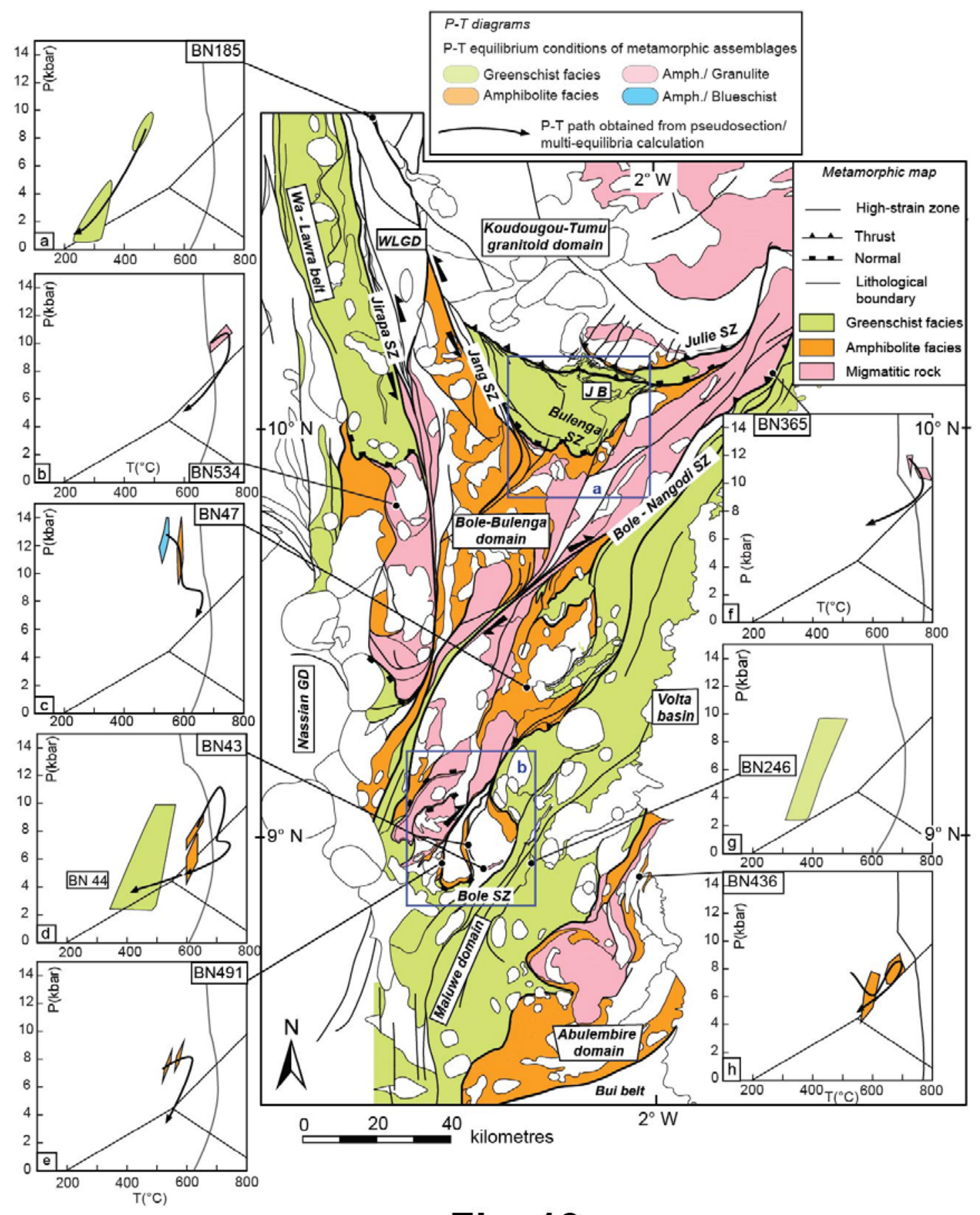

Fig. 13

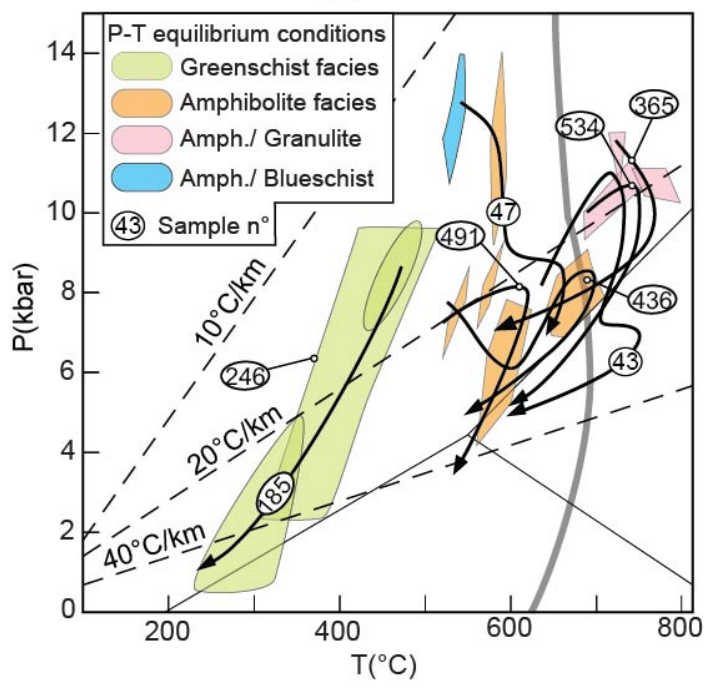


Fig. 14
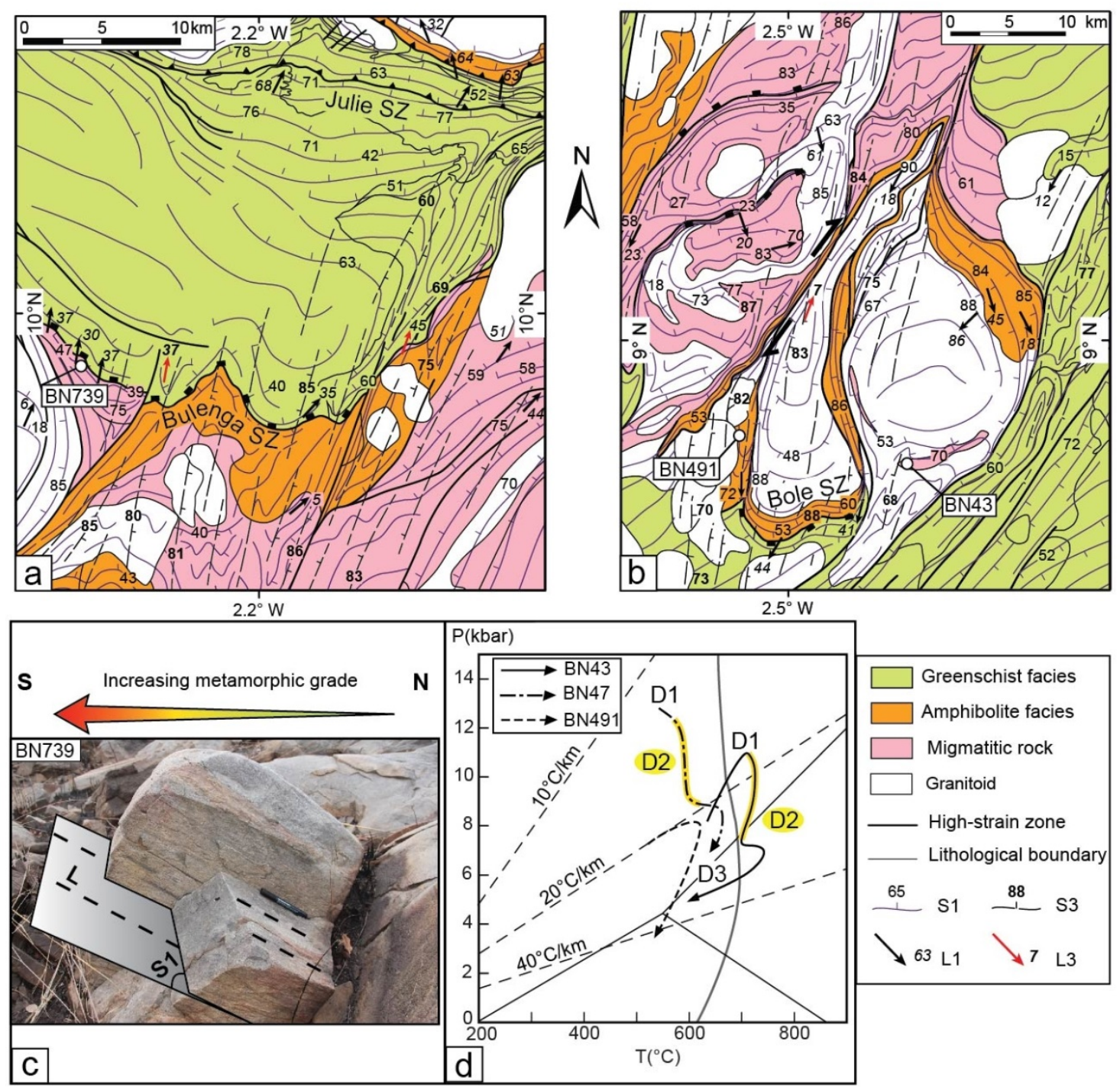
Fig. S1
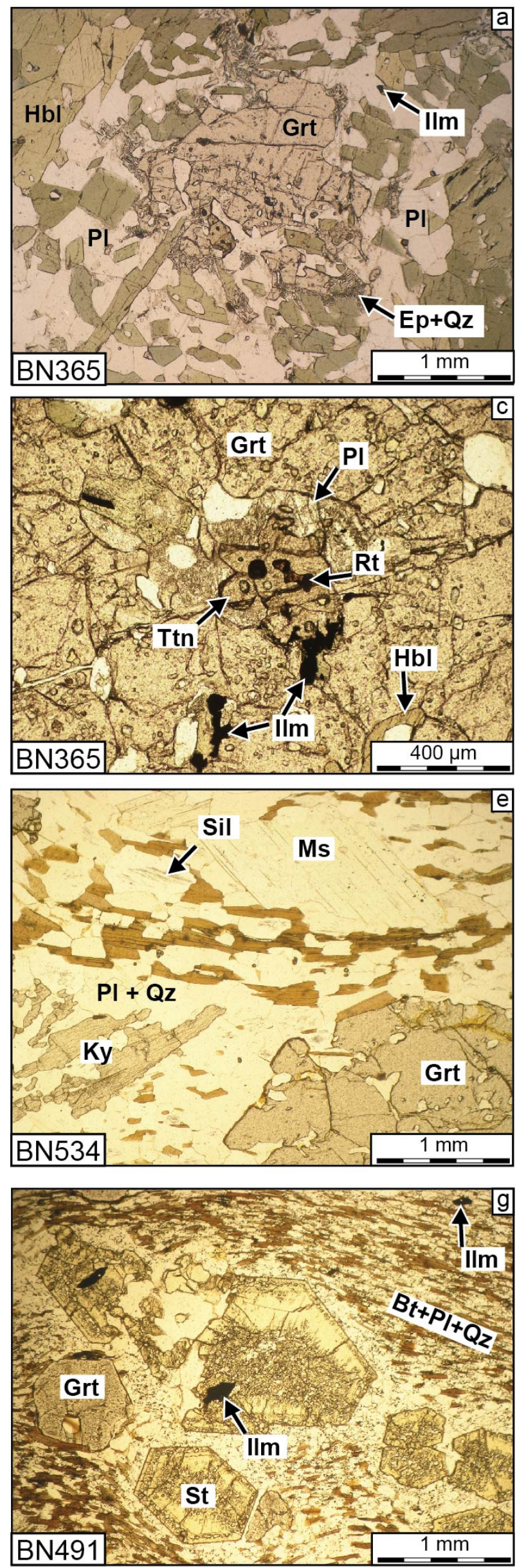
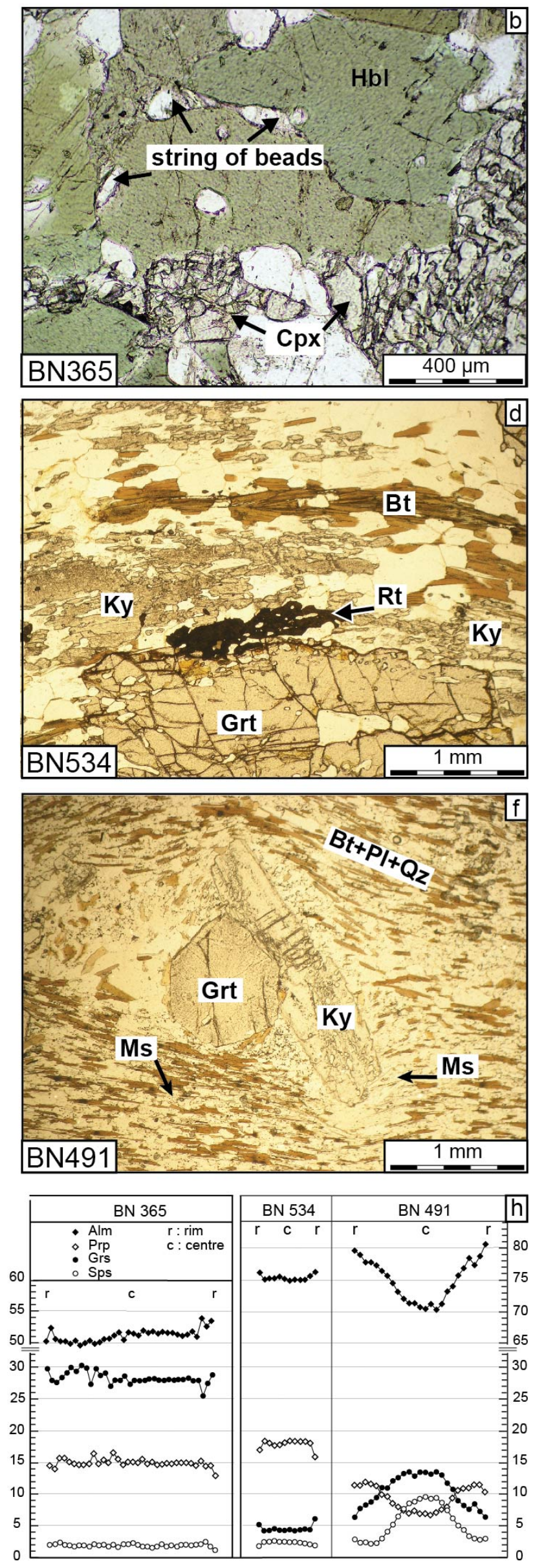
Fig. S2
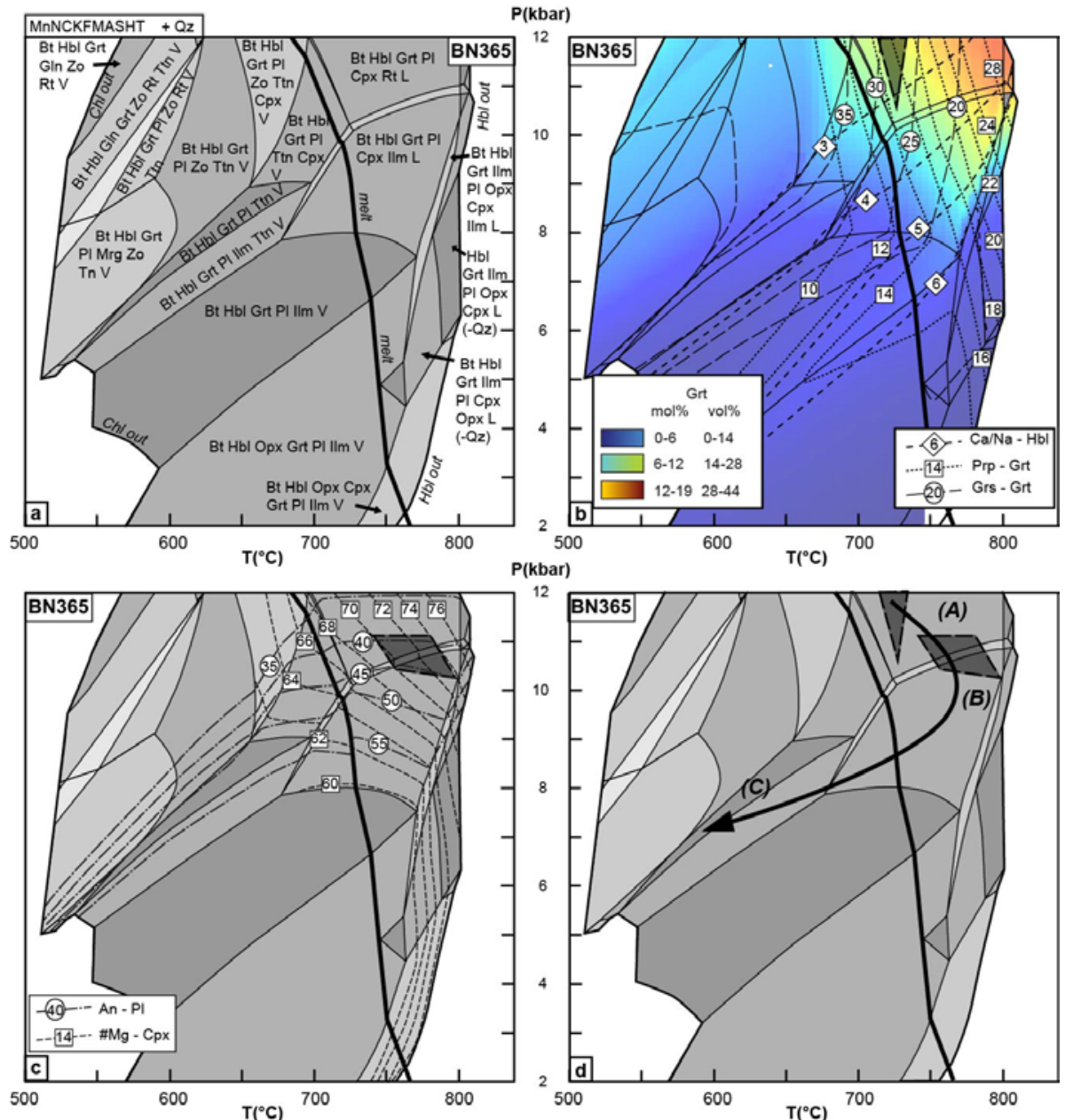

Fig. S3
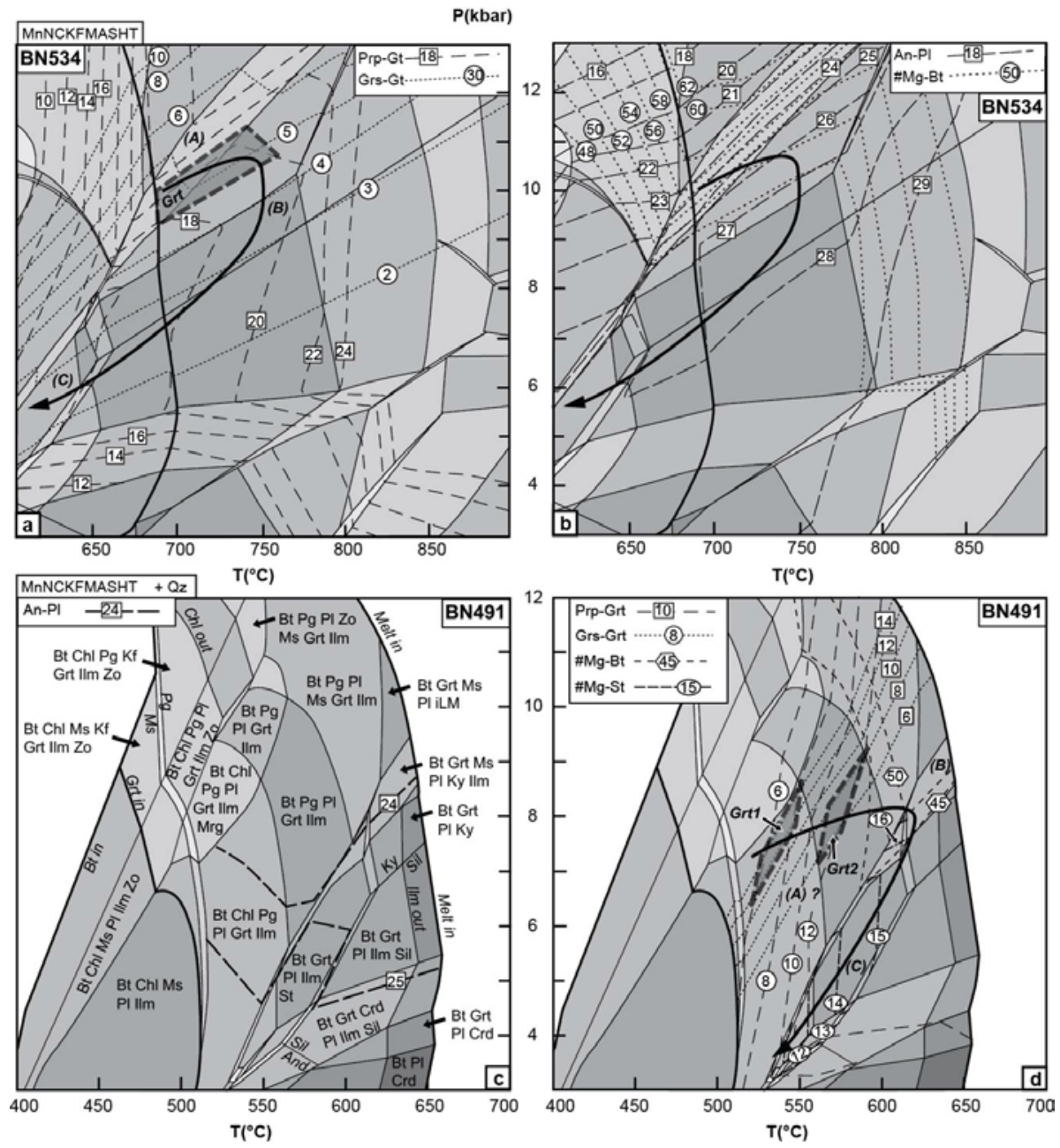